This report was prepared as an account of work sponsored by the United States Government. Neither. the United States nor the United States Atomic Energy Commission, nor any of their employees,. nor any of Commission, nor any of their employees,. nor any their contractors, subcontractors, or their emplos any makn accuracy, com- liability or responsibilion apparatus, pleteness or usefulness of any information, product or process disclosed, or represents that its use would not infringe privately owned rights.

\title{
ABSTRACT \\ INTERACTIONS OF DISSOLVED AND PARTICULATE NITROGEN IN LAKE METABOLISM
}

By

Bruce Andrew Manny

Weekly measurements of dissolved ammonia, nitrite, and nitrate for 22 months and organic nitrogen for 12 months were made in two hardwater lakes and seasonally in four other lakes representing a chemical and trophic spectrum in glaciated Michigan. Seston at $1 \mathrm{~m}$ depth was fractionated weekly for 14 months using $10 \mu \mathrm{m}$ Nitex netting in two lakes representing extremes of hardwater productivity. Net and nanno fractions were analyzed by micro-Kjeldahl digestion for organic nitrogen. Seasonal changes in all nitrogenous parameters were subsequently related to changes in fifteen other chemical and biological parameters assayed simultaneously.

More than half of total sestonic pigments, algal cell volume, and organic nitrogen were present all year in the nannosestonic fraction in the unproductive and productive lake. These data supported the hypothesis that nannophytoplankton contain more nitrogen per unit cell volume than netphytoplankton. 


\section{DISCLAIMER}

This report was prepared as an account of work sponsored by an agency of the United States Government. Neither the United States Government nor any agency Thereof, nor any of their employees, makes any warranty, express or implied, or assumes any legal liability or responsibility for the accuracy, completeness, or usefulness of any information, apparatus, product, or process disclosed, or represents that its use would not infringe privately owned rights. Reference herein to any specific commercial product, process, or service by trade name, trademark, manufacturer, or otherwise does not necessarily constitute or imply its endorsement, recommendation, or favoring by the United States Government or any agency thereof. The views and opinions of authors expressed herein do not necessarily state or reflect those of the United States Government or any agency thereof. 


\section{DISCLAIMER}

Portions of this document may be illegible in electronic image products. Images are produced from the best available original document. 
A high intensity ultraviolet combustion procedure was developed to measure dissolved organic nitrogen compounds (DON) at natural concentrations and later to differentiate UV-labile (LDON) and UV-refractory (RDON) fractions within the total DON pool in six lakes. LDON was always present in the more productive lakes in higher concentrations than RDON. Both fractions were present in higher concentrations in the epilimnion of all lakes than in the hypolimnion. RDON was unmeasurable in the most calcareous lake.

Measurements of allochthonous DON entering the most calcareous lake during the spring revealed LDON and RDON entered the lake. In the stream below the discharge of this lake, concentrations of LDON decreased during transport and concentrations of RDON increased. After $8 \mathrm{~km}$ of downstream transport, about $70 \%$ of the total DON was RDON. Measurements of DON during a leaf decomposition experiment in two recycling, enclosed streams suggested the percentage of RDON in the total DON was a dynamic equilibrium value that could be changed by terrestrial inputs and changes in the stream biota.

Collaborative work on DON sources to the most calcareous lake revealed RDON originated largely in the surrounding watershed whereas LDON originated largely within the lake--probably from the littoral flora and phytoplankton. 
Lastly, an array of pelagic DoN interactions is proposed to explain ways in which DON may regulate aquatic photosynthesis in hardwater lakes. Eutrophication rates stemming from various combinations of these interactions are proposed and discussed. 


\title{
INTERACTIONS OF DISSOLVED AND PARTICULATE \\ NITROGEN IN LAKE METABOLISM
}

By

Bruce Andrew Manny

A THESIS

\author{
Submitted to \\ Michigan State University \\ in partial fulfillment of the requirements \\ for the degree of \\ DOCTOR OF PHILOSOPHY
}

W. K. Kellogg Biological Station and

Department of Botany and Plant Pathology 


\section{ACKNOWLEDGMENTS}

I thank my guidance committee, Dr. Robert G. Wetzel (Chairman), Dr. Kenneth W. Cummins, Dr. Brian Moss, and Dr. Stephen N. Stephenson for their generous assistance and understanding throughout my program.

I am also grateful to: Dr. Robert C. Ball of Michigan State University, for the unpublished phosphorus data for 1955-1957 from Wintergreen Lake; Miss Mary Shaw for her prompt, unfailing assistance in obtaining library materials; Mr. Roswell E. VanDeusen for permission to study Wintergreen Lake; Mr. Wilbur C. (Joe) Johnson and Mr. W. S. White for cheerful year-round field assistance.

Financial support was provided by EPA Fellowship F1-WP-26, 378-02 to B. A. Manny; OWRR Grant 14-01-0001-3094 (B-009-Mich.) and AEC Contract AT (11-1)-1599, COO-1599-41 to R. G. Wetzel and NSF Grant GB-15665 to G. H. Lauff, et al., supporting the Coherent Area Research Project in Freshwater Ecosystems. 
TABLE OF CONTENTS

Page

LIST OF TABLES

LIST OF FIGURES.

Chapter

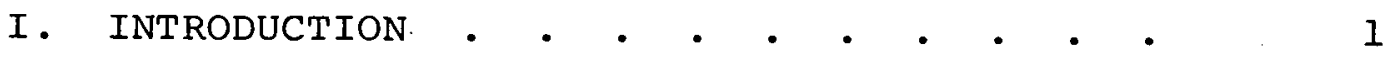

II. METHODS • • • • • • • • • • • •

A. Sampling Schedule . . . . . . . 3

B. Seston Fractionation . . . . . . .

C. Algal Enumeration . . . . . . . 8

D. Limnological Parameters . . . . . 99

E. Dissolved and Particulate Phosphorus. 10

F. Particulate Organic Nitrogen. . . . 13

G. Nitrate, Nitrite, Ammonia, Dissolved

Organic Nitrogen.

III. LIMNOLOGICAL BACKGROUND • • • • • • • • 16

A. Lawrence and Wintergreen Lakes . . . 16

1. Temperature, Oxygen, pH . . . . 21

2. Macrophytes, Zooplankton,
Phytoplankton . . . . . . 29

IV. INORGANIC NITROGEN AND PHOSPHORUS

INTERACTIONS • • • • • • • • • • 35

A. Hypolimnetic Transformations. . . . 35

1. Lawrence Lake Nitrogen . . . . 36

2. Wintergreen Lake Nitrogen . . . 48

3. Phosphorus in Lawrence and Wintergreen Lakes • . • . . . . 49 
B. Allochthonous Nitrogen and Phosphorus.

1. Aerial Nitrogen and Phosphorus .

2. Lawrence Lake. . . . . . . .

3. Wintergreen Lake. . . . . . . . 56

V. PARTICULATE ORGANIC NITROGEN INTERACTIONS •

A. Lawrence and Wintergreen Lakes

Phytoplankton.

B. Lawrence Lake Particulate Nitrogen. .

C. Wintergreen Lake Particulate Nitrogen.

VI. DISSOLVED ORGANIC NITROGEN INTERACTIONS. •

A. Introduction . . . . . • . . . 88

1. Previous DON Analytical Techniques. 89

2. UV Combustion. • • • • • • • 91

3. DON Production . . . . . . . . 91

4. DON Utilization • • • • • • • • • 96

B. Methods . . . . . . . . . . . 101

C. Results . . . • . • • • • • • 103

1. UV-labile and UV-refractory DON. . 103

2. Seasonal Changes in Six Michigan Lakes . . . . . . . . . . . 114

3. Allochthonous DON . . . . . . 128

D. Discussion of DON Results • . . . . 138

VII. GENERAL DISCUSSION. • • • • • • • • • • 145

A. The Nitrogen Cycle in Lawrence Lake. . 145

B. Role of Carbonate Particles . . . . 149

C. Role of Dissolved Organic Compounds. . 150

D. The Phosphorus Cycle in Hardwaters . . 152

E. Seston Fractionation. . . . . . . 153

F. Wintergreen Lake Spring Phytoplankton 157

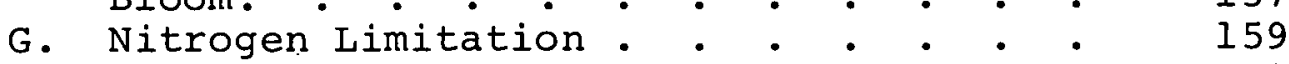

H. Lake Metabolism and Eutrophication . . 161

REFERENCES • • • • • • • • • • • • • • • 167 


\section{LIST OF TABLES}

Table

Page

1. Recovery of organic nitrogen from $1 \mathrm{mg}$ samples of organic compounds of various structural complexity by Kjeldahl procedure used in this study. . . . . . . . .

2. Comparison of morphometric and limnological parameters for Lawrence and Wintergreen lakes. Chemical parameters represent the annual range $(\mathrm{mg} / \mathrm{l})$ at $1 \mathrm{~m}$ depth . . . .

3. Nitrogen and phosphorus $(\mu \mathrm{g} / 1)$ present at four stations in Wintergreen Lake just prior to and immediately following ice-out on 6 April 1970

4. Dominant algal genera at $1 \mathrm{~m}$ depth in Lawrence and Wintergreen lakes during 1970-71.

5. UV-labile (LDON), UV-refractory (RDON), and total dissolved organic nitrogen (TDON) concentrations $(\mu \mathrm{g} / 1)$ in five Michigan lakes illustrating higher concentrations of LDON, RDON and TDON near the surface . . . . .

6. Concentrations of inorganic and organic nitrogen $(\mu \mathrm{g} / 1)$ after ultraviolet combustion of filtered water from two recycling, experimental streams • • • • • • . .

7. Percentage retention of total sestonic nitrogen and uncorrected chlorophyll a upon sample passage through $65 \mu \mathrm{m}$ and $10 \mu \mathrm{m}$ Nitex filter cloth. Values are means of duplicate trials using raw water from Wintergreen Lake. 


\section{LIST OF FIGURES}

Figure

Page

1. Bathymetic map of Lawrence Lake showing central sampling station $A$ used in this study

2. Bathymetric map of Wintergreen Lake showing sampling stations $A$ and $B$ used in this study.

3. Total dissolved phosphorus $(\mu \mathrm{g} / 1)$ determined over a 12-month period on filtered water from Lawrence and Wintergreen lakes using ultraviolet combustion and the method of strickland and Parsons (1968). Dotted line represents theoretical 1:1 correspondance.

4. (A) Water level (B) Temperature isopleths (C) Temperature at $1 \mathrm{~m}$ depth and (D) Secchi disc transparency in Lawrence Lake from July 1969 to May 1971. Opaque areas represent ice cover to scale. . . . . . . . . . .

5. (A) Rainfall (B) Water level (C) Secchi disc transparency (D) Temperature at $1 \mathrm{~m}$ depth and (E) Temperature isopleths in Wintergreen Lake from July 1969 to May 1971. opaque areas represents ice cover to scale.

6. Isopleths of dissolved oxygen $(\mathrm{mg} / \mathrm{l}), \mathrm{pH}$, and $14 \mathrm{C}$ productivity (mg $\mathrm{C} / \mathrm{m}^{3} / \mathrm{da}$ ) in Lawrence Lake from July 1969 to May 1971. Opaque areas represent ice cover to scale . . . . .

7. Isopleths of $\mathrm{pH}$ at Station $\mathrm{B}$ in Wintergreen Lake from October 1970 to May 1971. Opaque area represents ice cover to scale . . . 
Figure

8. Annual cycles of (A) Nitrate (left) and ammonia (right) in $\mathrm{mg} / \mathrm{l}$ (B) Total phosphorus in filtered (shaded area) and unfiltered water $(\mu \mathrm{g} / 1)$ (C) sediment temperature minus the temperature of water at $12 \mathrm{~m}$ depth $\left({ }^{\circ} \mathrm{C}\right)$ and (D) Conductivity ( $\mu$ mhos @ 25C), $\mathrm{pH}$ and dissolved oxygen concentrations (mg/l) at $12 \mathrm{~m}$ depth in Lawrence Lake from July 1969 to May 1971 . . . . . . . . . . .

9. Annual cycles in $\mathrm{mg} / \mathrm{l}$. of (A) Nitrate and ammonia (B) Total phosphorus in filtered (shaded area) and unfiltered water during 1969-70 (C) Total phosphorus in unfiltered water during 1955-57 and (D) sediment temperature minus water temperature at $5 \mathrm{~m}$ depth $\left({ }^{\circ} \mathrm{C}\right)$ in Wintergreen Lake from August 1969 to April 1971. Unpublished phosphorus data for 1955 to 1957 were provided by Dr. R. C. Ball of Michigan State University . . . . . . .

10. Isopleths of nitrate (mg/1), nitrite ( $\mu \mathrm{g} / 1)$ and ammonia $(\mu \mathrm{g} / 1)$ in Lawrence Lake from August 1970 to April 1971. Opaque area represents ice cover to scale . . . . . .

11. Isopleths of nitrate (mg/l), nitrite ( $\mu \mathrm{g} / 1)$, ammonia (mg/l) and total dissolved phosphorus $(\mu \mathrm{g} / 1)$ in Wintergreen Lake from October 1970 to April 197

12. Wintergreen Lake showing locations of visible nutrient sources, associated lagoon complex and sampling stations during March and April 1970

13. Relative percentage abundance of net and nannophytoplankton of the three major phyla by numbers, surface area and volume per liter at $1 \mathrm{~m}$ depth in Lawrence and Wintergreen lakes during 1970 . . . • . • . • • .

14. Total sestonic nitrogen, nannosestonic nitrogen and percentage nannosestonic nitrogen with total algal cell volume, nanno algal cell volume and percentage nanno cell volume at $1 \mathrm{~m}$ depth in Lawrence Lake from July 1969 to october 1970 
15. Organic nitrogen content per unit algal cell volume in the net and nanno size categories at $1 \mathrm{~m}$ depth in Lawrence Lake from November 1969 to september 1970 . . . . . . .

16. Corrected chlorophyll a in the total seston and nannoseston and percentage nanno chlorophyll a at $1 \mathrm{~m}$ depth in wintergreen Lake from JuIy 1969 to September 1970 . . .

17. Organic nitrogen content of the total seston and nannoseston and percentage nanno organic nitrogen at $1 \mathrm{~m}$ depth in Wintergreen Lake from July 1969 to September 1970. . . . .

18. Total algal cell volume, nanno algal cell volume and percentage nanno algal cell volume per liter at $1 \mathrm{~m}$ depth in Wintergreen Lake from July 1969 to September 1970 . • • • •

19. Organic nitrogen content per unit algal cell volume in the net and nanno size categories at $1 \mathrm{~m}$ depth in Wintergreen Lake from November 1969 to September 1970 . • • • .

20. Algal surface area to volume ratios for net and nanno size categories in Lawrence and Wintergreen lakes at $1 \mathrm{~m}$ depth from February 1970 to February 1971 . . . . . . .

21. Percentage recovery of 400 or $600 \mathrm{\mu g} / 1$ glycine-N after 0.5 hr combustion in distilled water solutions and water from wintergreen Lake containing different amounts of dissolved organic carbon as glucose and potassium hydrogen pthalate . . . . . .

22. Percentage of final $(2.0 \mathrm{hr})$ LDON and RDON release and percentage of final $\mathrm{NO}_{3}$ reduction at the indicated times during irradiation of water from $1 \mathrm{~m}$ depth in Lawrence and Wintergreen lakes from May 1970 to March 1971 .

23. Net changes in $\mathrm{NO}_{3}+\mathrm{NO}_{2}$ (hatched bars), $\mathrm{NO}_{2}$ (left-middle bars), $\mathrm{NO}_{3}$ (right-middle bars) and $\mathrm{NH}_{4}$ (open bars) after $2 \mathrm{hr}$ UV irradiation of water from Lawrence and Wintergreen lakes during the summer months 1970. Hatched bars equal RDON and open bars equal LDON for each date 
24. Seasonal net changes in (left to right) $\mathrm{NO}_{3}+\mathrm{NO}_{2}$ (RDON), $\mathrm{NO}_{2}, \mathrm{NO}_{3}$ and $\mathrm{NH}_{4}$ (LDON) in six Michigan lakes during the month/year indicated. Shaded areas represent the net change, after $0.5 \mathrm{hr}$ irradiation, of each component. February 1970 combustions of Purdy, Duck, Cassidy and Gull lakes were of $<1.0 \mathrm{hr}$ duration; other combustions were of $2.0 \mathrm{hr}$ duration . . . . . . . .

25. Comparison of annual changes in LDON, average TDOC and rates of $14 \mathrm{C}$ primary productivity in the $0-2 \mathrm{~m}$ stratum of Lawrence Lake from May 1970 to March 1971 .

26. Annual changes in concentrations of LDON and RDON at $1 \mathrm{~m}$ depth in Wintergreen Lake from April 1970 to March 1971 . . . . . . .

27. Correlation between total dissolved organic carbon and nitrogen $(\mathrm{N}=7)$ at $1 \mathrm{~m}$ depth in Lawrence Lake from February to July 1970. Correlation does not include the datum from 4 August 1970 at right. • • • • • • •

28. Total dissolved organic carbon and nitrogen data from $1 \mathrm{~m}$ depth in Lawrence lake from February 1970 to February 1971, illustrating the lack of a consistent annual relationship. See text for explanation of square points with dates . . . . . . . . .

29. Comparison of annual changes in LDON and algal cell volume represented by members of the Chlorophyta and Chrysophyta larger than $10 \mu \mathrm{m}$ at $1 \mathrm{~m}$ depth in Lawrence Lake from May 1970 to March 1971. . . . . . • .

30. Average contributions of organic and inorganic nitrogen by visible allochthonous sources to Lawrence Lake during 21-29 April 1971. (A) Primary inflow from north marsh (B) Primary inflow from west marsh (C) Entrance of (A) into the lake (D) Entrance of (B) into the lake (E) Vernal spring (F) Deeply stained occasional inflow from northeast marsh (0) Outflow to Augusta Creek 
31. Organic and inorganic nitrogen concentrations on 24 April 1971 at several stations in

Augusta Creek (Barry and Kalamazoo counties, Michigan) below the Lawrence Lake discharge. shaded areas represent extensive marsh lands.

32. Pelagic DON interactions and transformations. Heavier vectors indicate major pathways and potential regulatory mechanisms of aquatic photosynthesis in hardwater lakes. 


\section{INTRODUCTION}

The first objective of this work was to relate changes in inorganic nitrogen concentrations and standing stocks of sestonic organic nitrogen to understand how these two parameters relate to production of organic nitrogen. Two lakes representing extremes of hardwater productivity were sampled weekly for over one year to compare rates of allochthonous nitrogen entry, rates of nitrogen regeneration and organic nitrogen production in each lake.

Nitrogen content of net- and nannoseston size fractions (Hutchinson, 1967:235) were determined to see whether nannoplankton was responsible for more organic nitrogen production than the netplankton. In other systems, nannoplankton has been shown to be responsible

for more than half the ${ }^{14} \mathrm{C}$-fixation (Rodhe, Vollenweider and Nauwerck, 1958; Holmes and Anderson, 1963; Wetzel, 1964, 1966), and to comprise more than half the plankton biomass (Banse, 1961), algal cell volume (Willen, 1959; 1961) and cell numbers and chlorophyll content (Yentsch and Ryther, 1958). Fractionation also permitted estimation of nannoplankton consumability and food quality, both 
important properties in the structure and dynamics of aquatic communities (Hall, Cooper and Werner, 1970). Lastly, analytical techniques were developed to quantify changes in dissolved organic nitrogen (DON) in natural waters (Manny, Miller and Wetzel, 1971) because cyclic changes in dissolved organic matter (DOM) are intimately related to mechanisms regulating rates of energy and materials transfer in lake metabolism and eutrophication (Wetzel, 1965, 1966, 1967, 1969, 1970; Wetzel and Allen, 1971). Because amino acids readily adsorb on calcium carbonate particles (Wetzel and Allen, 1971) and form complexes with trace-metals essential for photosynthesis (Albert, 1950, 1952, 1953), it was thought that DON might be a major active DOM fraction controlling metabolic processes in hardwater lakes. 


\section{METHODS}

\section{A. Sampling Schedule}

Water samples were collected on the same day each week from August 1969 to October 1970 from $1 \mathrm{~m}$ depth over Station A in Lawrence Lake (Figure 1) and from $0.5 \mathrm{~m}$ depth over Station A in Wintergreen Lake (Figure 2) using a 3liter Van Dorn sampler. After October 1970, collections were made biweekly at meter intervals at station $A$ in Lawrence Lake and Station B in Wintergreen Lake. Temperature was measured at meter intervals using a thermistor (Model 43TB, Yellow Springs Instr. Co., Yellow Springs, Ohio)

\section{B. Seston Fractionation}

Seston was fractionated for particulate nitrogen and phosphorus analysis by passing duplicate samples through $10 \mu \mathrm{m}$ nylon Nitex filter cloth (Tobler, Ernst and Traber, N.Y., N.Y.) and a glass fiber filter of approximately $0.3 \mu \mathrm{m}$ porosity (Reeve Angel $984 \mathrm{H}$, Clifton, N.J.) separated by $1 \mathrm{~mm}$ Nitex filter cloth. Nitex $10 \mu \mathrm{m}$ filter cloth retains all particles $>30 \mu \mathrm{m}$ in diameter, $50 \%$ of particles $10 \mu \mathrm{m}$ in diameter and passes particles $4 \mu \mathrm{m}$ or less in diameter (Sheldon and Sutcliffe, 1969). Seston 
Figure 1. Bathymetric map of Lawrence Lake showing central sampling station A used in this study. 


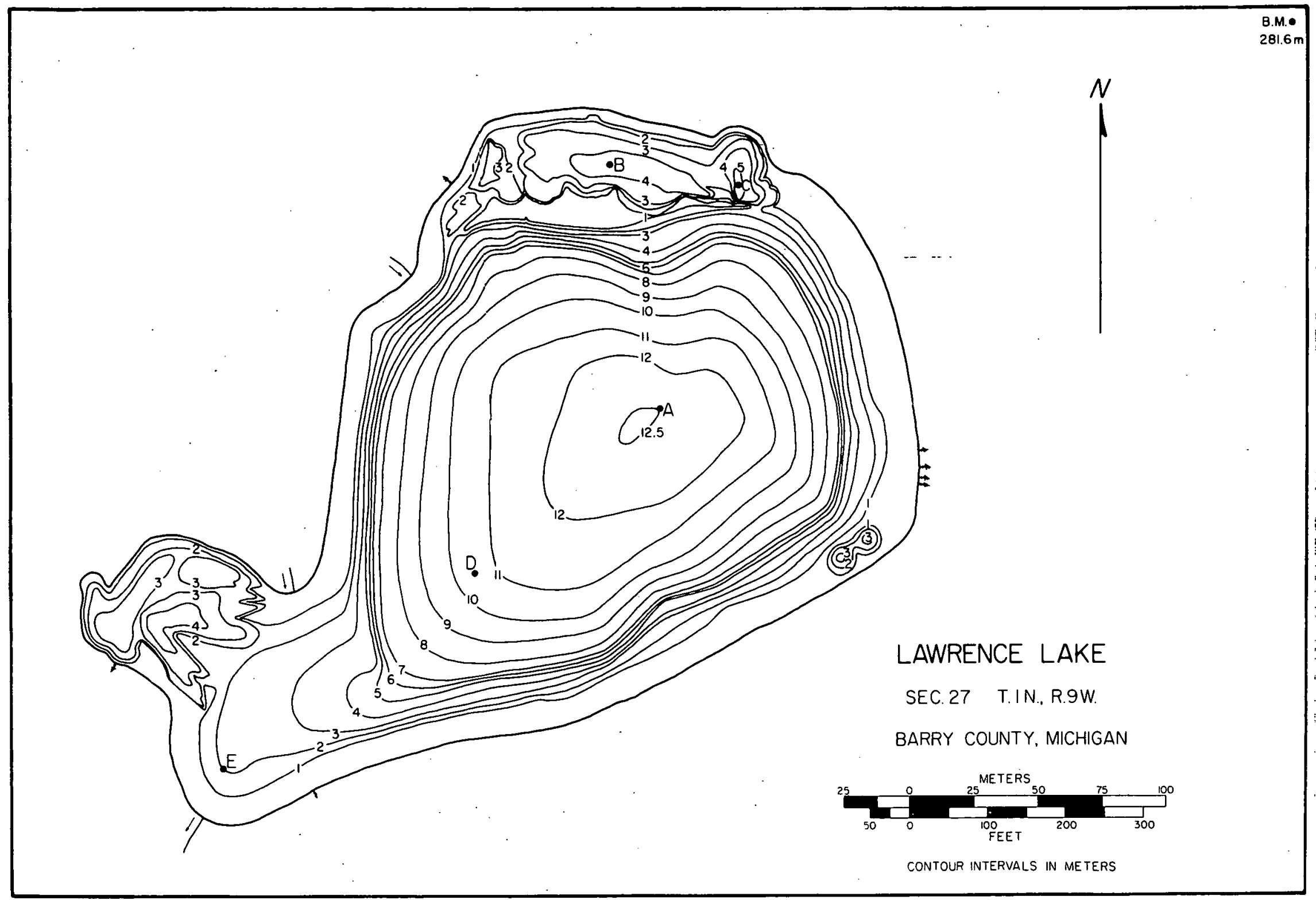


Figure 2. Bathymetric map of wintergreen Lake showing sampling stations $A$ and $B$ used in this study. 


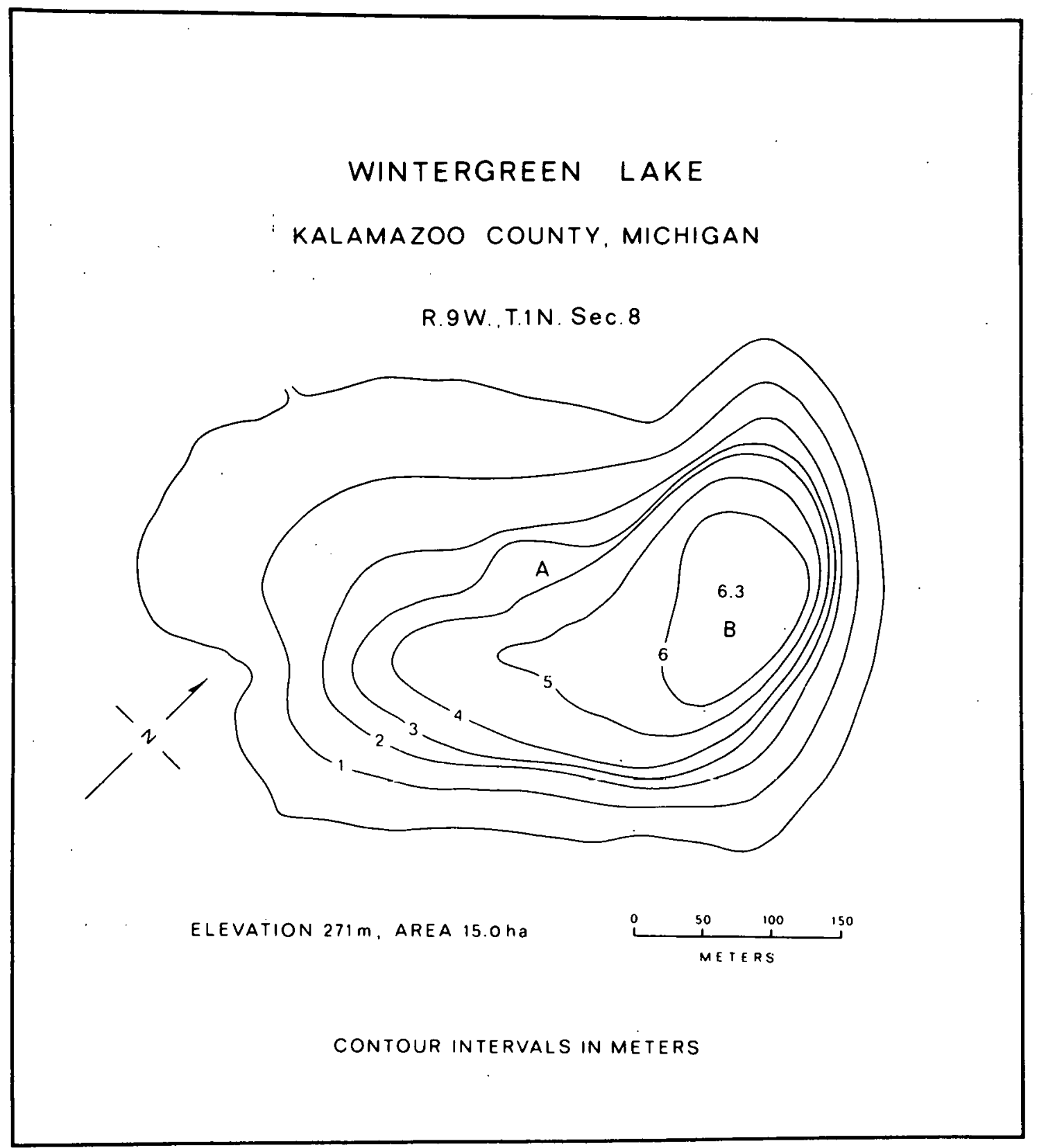


caught upon the $10 \mu \mathrm{m}$ Nitex was rinsed with distilled water onto another glass fiber filter and designated netseston. Seston passing the $10 \mu \mathrm{m}$ Nitex and caught upon the glass fiber filter was designated nannoseston in conformance with original conventions (Lohmann, 1903). The filtrate was analyzed for dissolved components. Fractionation for pigment analysis was accomplished by substituting a membrane filter of $0.8 \mu \mathrm{m}$ porosity (Grade AA, Millipore Corp., Bedford, Mass.) for the glass fiber filter. Pigments were extracted by grinding the filtered seston in $90 \%$ basic acetone for one minute with an airdrive teflon to glass pestle (Model 4288-C, A. H. Thomas Co., Phila., Pa.). Approximately 0.2-0.4 g glass microspheres, 10-30 $\mu \mathrm{m}$ in diameter, were ground with samples from Wintergreen Lake to obtain complete pigment extraction. After 15-20 minutes, extracts were centrifuged for 10 minutes at $3,500 \mathrm{rpm}$ and the absorbance read at 750,665 , 645, 630 and $480 \mathrm{~nm}$ (Hitachi Perkin-Elmer, model 139). Chlorophyll a corrected for pheopigments was calculated using the equations of Parsons and Strickland (1963) as modified by Wetzel and Westlake (1969).

\section{Algal Enumeration}

Surface area and cell colume for net and nanno phytoplankton were determined from water samples preserved with acidified Lugol's solution (Edmondson, 1959:1200) by the settling-chamber technique using an inverted microscope 
(Lund, et al., 1958; Utermöhl, 1958). Members of phyla other than the Chlorophyta, Cyanophyta and Chrysophyta were grouped with one of these major phyla on the basis of pigment similarity (Round, 1965:160). Primarily, this resulted in the inclusion of occasional Euglenophytes among the Chlorophyta and, more frequently, small cryoptophytes among the Cyanophyta. Identifications were made by reference to Smith (1950), Prescott (1954, 1962), Graffius (1963) and Patrick and Reimer (1966). In calculations of volume and surface area, nannoplankton was arbitrarily differentiated from netplankton on the basis of whether representative members of the population possessed a dimension $10 \mu \mathrm{m}$ or less, excluding very large forms like the diatom Synedra which meet this criterion but would only rarely pass a $10 \mu \mathrm{m}$ Nitex filter. Dimensions were not corrected for observed differences between fresh and preserved specimens (Ahlstrom and Thrailkill, 1961). A constant eccentricity of 0.4 was assumed for all cells and colonies approximating an ellipse. Other forms were approximated to a sphere or cylinder.

\section{Limnological Parameters}

Rates of photosynthetic carbon fixation were measured biweekly in Lawrence Lake by ${ }^{14} \mathrm{C}$ techniques (Goldman and Wetzel, 1963; Wetzel, 1965). Daily production estimates were extrapolated by interpolation of insolar radiation curves (Vollenweider and Nauwerk, 1961; Miller, 1971). 
Sample $\mathrm{pH}$ was determined electrometrically within one hour after collection (Beckman Model 76-A pH meter); dissolved oxygen was determined by the Alsterberg modification of the Winkler titration (APHA 1960); major cations were determined by flame atomic adsorption (Jarrell Ash Model 82-700) and total dissolved organic carbon was determined by persulfate oxidation and infra-red $\mathrm{CO}_{2}$ analysis (Wetzel, 1969) .

\section{$\underline{\text { E. Dissolved and Particulate Phosphorus }}$}

Total phosphorus was determined in filtered and unfiltered water within three hours of collection by perchloric acid digestion (Strickland and Parsons, 1968) or combustion with high intensity ultraviolet (UV) light. Water for the latter procedure was at $\mathrm{pH} 3-4$ and contained boric acid for determination of dissolved organic nitrogen (Manny, Miller and Wetzel, 1971). Limits of sensitivity and two standard errors for the perchloric acid procedure were 2-4 and $2.04 \mu \mathrm{g} / 1$ respectively using a $10-\mathrm{cm}$ light path $(\mathrm{N}=5)$. For samples combusted with UV light, the sensitivity and two standard errors using a 10-cm light path were $2-3$ and $1.12 \mu \mathrm{g} / 1$ respectively $(\mathrm{N}=8)$.

Values for total dissolved-P by either procedure were not significantly different from each other in the range of 2-200 $\mathrm{\mu g} / \mathrm{l}(\mathrm{P}>0.01, \mathrm{~N}=55)$ (Figure 3 ). 
Figure 3. Total dissolved phosphorus $(\mu \mathrm{g} / 1)$ determined over a 12-month period on filtered water from Lawrence and Wintergreen lakes using ultraviolet combustion and the method of Strickland and Parsons (1968). Dotted line represents theoretical $1: 1$ correspondance. 


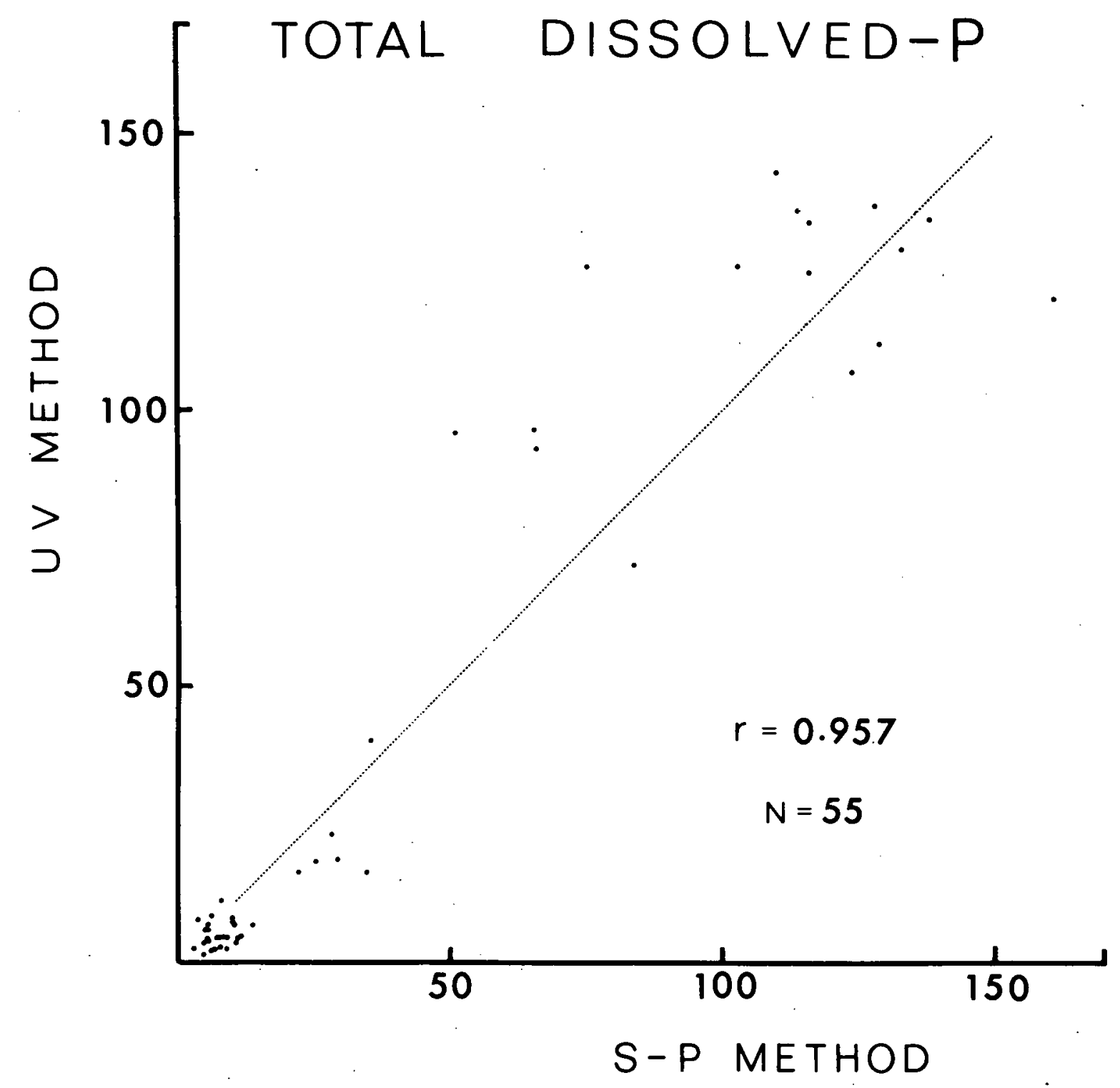




\section{F. Particulate Organic Nitrogen}

Particulate organic nitrogen was determined for the period August 1969 to september 1970 by Kjeldahl digestion (Golterman, 1969) followed by distillation (Markham, 1942). Because nitrogen atoms bound in carbon ring structures are seldom recovered without severe prereduction and hydrolysis (Kirk, 1950; Steyermark, 1961; Bradstreet, 1965), digestion was tested by analyzing nitrogenous reference standards of different structural complexity (Anonymous, 1953). Digestion consisted of boiling the sample for $3 \mathrm{hr}$ in a 30 $\mathrm{ml}$ Kjeldahl flask in the presence of $5 \mathrm{ml}$ concentrated $\mathrm{H}_{2} \mathrm{SO}_{4}, 3 \mathrm{~g} \mathrm{~K}_{2} \mathrm{SO}_{4}, 3$ glass beads, $1 \mathrm{ml} 10 \% \mathrm{NaCl}-5 \% \mathrm{CuSO}_{4}$ solution and enough water to rinse the neck of the flask (Golterman, 1969). Results (Table 1) indicate partial recovery of nitrate and ring-bound nitrogen, complete recovery of amino-N and excellent agreement with Biuret determinations of crude total protein in insect homogenate. Limiting sensitivity of this procedure was $3-5 \mu \mathrm{g} / 1$; $95 \%$ confidence limits about mean determinations of samples in the range $20-250 \mu \mathrm{g} / 1$ varied from \pm 3.09 to \pm 19.50 $\mu \mathrm{g} / \mathrm{I}(\mathrm{N}=5)$.

G. Nitrate, Nitrite, Ammonia, Dissolved Organic Nitrogen

Nitrate, nitrite and ammonia were determined after Manny et al. (1971) from August 1969 to April 1970 on filtrates stored several months at $-20^{\circ} \mathrm{C}$. After April 1970, samples were analyzed immediately or refrigerated 
Table 1. Recovery of organic nitrogen from $1 \mathrm{mg}$ samples of organic compounds of various structural complexity by Kjeldahl procedure used in this study.

\begin{tabular}{lcc}
\hline Compound & Structure & $\begin{array}{r}\text { \% } \\
\text { Recovery }\end{array}$ \\
\hline Alanine & $\mathrm{C}-\mathrm{C}-\mathrm{C}_{\substack{1 \\
\mathrm{NH}_{2}}}$
\end{tabular}

Melamine<smiles>NC1=NC(N)NC(N)N1</smiles>

p-Nitro alanine<smiles>NC1CCC([N+](=O)[O-])CC1</smiles>

$$
76.4
$$

DNA (not highly

polymerized)

Biuret protein of

insect homogenate*

106.6

Average Recovery

97.1

*Neophylax oligius (Trichoptera, Limnephilidea) analyzed by R. C. Petersen. 
at $4^{\circ} \mathrm{C}$ for analysis within two days. Internal standards of $100 \mu \mathrm{g} / 1 \mathrm{NH}_{4}-\mathrm{N}$ were included with each sample sequence from each lake to assess a factor by which values were corrected to compensate for consistent incomplete $\mathrm{NH}_{4}-\mathrm{N}$ recovery caused by sensitivity of the method to $\mathrm{pH}$ and the presence of other nitrogenous compounds (Harwood and Huyer, $1970 \mathrm{a}, 1970 \mathrm{~b})$. Recovery of added $\mathrm{NH}_{4}-\mathrm{N}$ in samples from Lawrence Lake varied from 30 to $110 \%(\overline{\mathrm{x}}=79.07 \%, \mathrm{~N}=31)$ and was consistently less than that in water from wintergreen Lake $(\bar{x}=83.92, N=29$; Range 40 to 100\%).

UV-labile and UV-refractory dissolved organic nitrogen fractions (DON) were determined after Manny et al. (1971) except that samples combusted after 18 January 1971 contained $3 \mathrm{~g}^{-1}$ rather than $500 \mathrm{mg} \mathrm{l}^{-1} \mathrm{HBO}_{3}$ to overcome occasional unexplained increases in $\mathrm{pH}$ observed during combustion.

Most points on the figures are mean values of at least duplicate analyzes, however, replicate samples were not collected from the same depth or from more than one station frequently enough to estimate field variation. While the data may not be interpreted statistically, clear seasonal trends in the data are interpreted and discussed. 


\section{LIMNOLOGICAL BACKGROUND}

Lakes considered in this study are located in Barry and Kalamazoo counties, southwestern Michigan on a southern outwash apron of the Kalamazoo morain (Leverett and Taylor, 1915; Hough, 1958, 1963). Soils of the area developed upon glacial till high in $\mathrm{CaCO}_{3}$ and vary from deep, poorly drained Carlisle muck to sandy, well-drained Fox loam (Perkins and Tyson, 1922; Deeter and Trull, 1928; Whiteside et al., 1968). Watersheds surrounding the lakes are characterized by undulating plains of low relief dotted with frequent valley depressions. Nearly $80 \%$ of the land is cultivated or used for grazing of cattle, the remainder is second-growth woodland of oak, hictory, maple, aspen and occasional plantings of conifers.

\section{A. Lawrence and Wintergreen Lakes}

Two lakes were chosen for intensive study which were readily accessible all year and known to differ in general chemistry, including forms of nitrogen. An extensive background of related measurements being made concurrently in Lawrence Lake and the contrasting trophic extremes in Wintergreen Lake provided overlapping ranges of biological and chemical parameters for investigations 
of the interactions of dissolved organic compounds and nutrient cycles in lake metabolism. Morphometric and chemical data for Lawrence and Wintergreen lakes are summarized in Table 2; chemical data for the remaining lakes has been published elsewhere (Manny et al., 1971). Deeper, less productive Lawrence Lake (Figure 1 ) is surrounded by a watershed of cultivated fields of corn and. low marshes approximately 10 times the surface area of the lake. Half the water enters the lake as two small spring-fed streams and several smaller springs; the remainder enters from submerged springs. A single outflow terminates $0.75 \mathrm{~km}$ south in Augusta Creek. Lawrence is calcareous and contains extensive deposits of nearly pure $\mathrm{CaCO}_{3}$ which have been extensively excavated at several sites since settle-. ment of the watershed in the 1830's (Rich, 1970b). Shallower, more productive wintergreen (Figure 2) has benthic marl deposits (Scheibner, 1958) and is nearly surrounded by a belt of oak, hictory and pine trees approximately 20-50 $\mathrm{m}$ wide which is bordered by fields under intermittent cultivation. Surface area of the watershed is 7-10 times that of the lake. Other than surface runoff, visible inflow to Wintergreen is limited to one small intermittent stream originating in a dairy farm feed-lot about $0.5 \mathrm{~km}$ north of the lake. In the spring, water flows over a small dam at the outlet and $0.3 \mathrm{~km}$ west to Gull Lake. 
Table 2. Comparison of morphometric and limnological parameters for Lawrence and Wintergreen lakes. Chemical parameters represent the annual range $(\mathrm{mg} / \mathrm{I})$ at $1 \mathrm{~m}$ depth.

\begin{tabular}{|c|c|c|}
\hline Parameter & $\begin{array}{l}\text { Lawrence } \\
\text { (Barry Co.) }\end{array}$ & $\begin{array}{c}\text { Wintergreen } \\
\text { (Kalamazoo Co.) }\end{array}$ \\
\hline Basin $^{a}$ & Type 35 & Type 36 \\
\hline Length (m) & 342 & 544 \\
\hline width (m) & 224 & 375 \\
\hline Area (ha) & 4.96 & 14.98 \\
\hline Volume $\left(\mathrm{m}^{3}\right)$ & 292,349 & 530,584 \\
\hline Maximum Depth (m) & 12.6 & 6.3 \\
\hline Mean Depth (m) & 5.89 & 3.54 \\
\hline 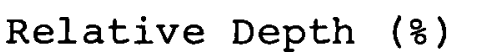 & 5.01 & 1.44 \\
\hline Volume Development & 1.42 & 1.69 \\
\hline Shore Development & 1.29 & 1.15 \\
\hline UV-labile DON & $0.07-0.22$ & $0.50-1: 37$ \\
\hline UV-refractory DON & $<0.03$ & $0.22-0.52$ \\
\hline TDON & $0.07-0.22$ & $0.62-1.60$ \\
\hline $\mathrm{NO}_{3}$ & $2.0-3.0$ & $0.005-1.34$ \\
\hline $\mathrm{NO}_{2}$ & $0.014-0.025$ & $0.012-0.040$ \\
\hline $\mathrm{NH}_{4}$ & $0.01-0.21$ & $0.005-2.32$ \\
\hline Total Dissolved P & $0.003-0.01$ & $0.02-0.13$ \\
\hline Total Dissolved C & $3.45-7.43$ & $6.0-9.1$ \\
\hline
\end{tabular}


Table 2. Continued

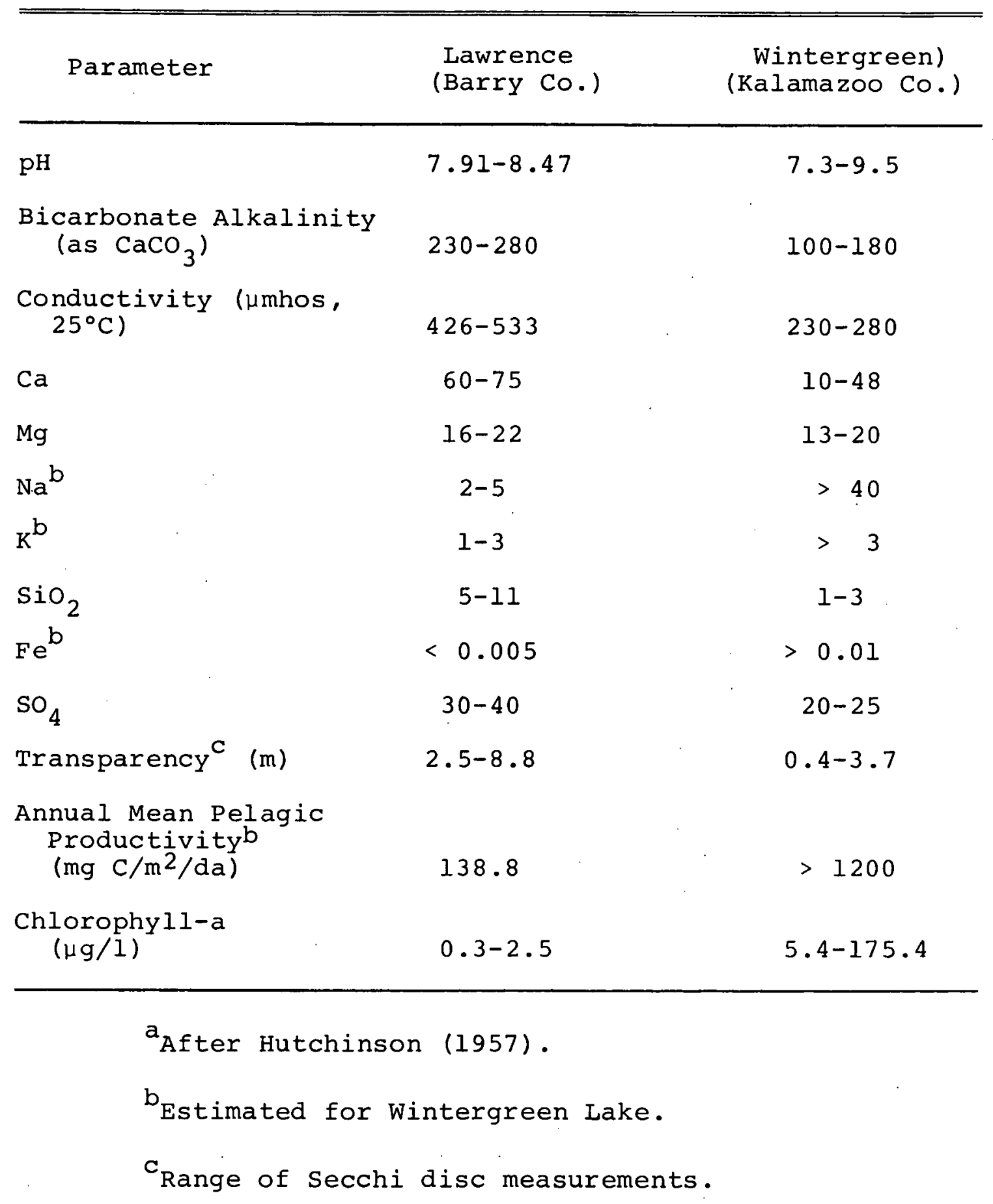


Dominance of the ionic composition in the water by $\mathrm{HCO}_{3}, \mathrm{Ca}$, and $\mathrm{Mg}$ (Table 2) identifies both lakes as alkaline hardwater lakes characteristic of those originating in glacial till (Wetzel, 1966a, 1966b). Lawrence Lake is deeper, less productive and more buffered than Wintergreen Lake, however, concentrations of dissolved organic nitrogen (DON), $\mathrm{P}, \mathrm{NH}_{4}, \mathrm{Na}, \mathrm{Fe}, \mathrm{SO}_{4}$ and chlorophyll-a in Wintergreen are frequently ten times those in Lawrence. Excepting the interesting sustained milligram $\mathrm{NO}_{3}$ concentrations in Lawrence (discussed below) these criteria identify Lawrence as oligotrophic and wintergreen as polytrophic (Vollenweider, 1968). Annual mean productivity values identify Lawrence and Wintergreen as oligotrophic and hypereutrophic respectively (Wetzel, 1966a). This latter designation, based on compression of the trophogenic zone to a point where light rather than available nutrients limits productivity (Vollenweider, 1960; Wetzel, 1966a) describes conditions in wintergreen during most periods of the year. Wintergreen resembles other hypereutrophic lakes in having an anoxic hypolimnion more than 8 months of the year and rapid pronounced fluctuations in $\mathrm{pH}$ and other chemical parameters diurnally and seasonally (Sloey, 1970).

Annual precipitation and snowfall in Barry and Kalamazoo counties average 86.3 and $129.5 \mathrm{~cm}$ respectively (U.S. Weather Bureau Records, W. K. Kellogg Biological Station). Highest rainfall was received in the months of 
July, October and November. Rain during these months and the spring thaw in January coincided with periods of maximum water levels in both lakes (Figures 4 and 5). Icecover lasted from 7-15 December to 3-7 April on both lakes but ice thickness on Wintergreen $(42 \mathrm{~cm}$ max.) was always greater than that on Lawrence ( $36 \mathrm{~cm} \max$. ) owing to the greater latent heat energy stored in the latter.

\section{Temperature, Oxygen, $\mathrm{pH}$}

Temperature data for Lawrence Lake (Figure 4) reveals that it was second-order and dimictic (Hutchinson, 1957) with approximately two weeks of complete mixing in November 1969 and one week of complete mixing immediately following ice melt in April 1970. Hypolimnetic conditions arising from strong thermal stratification and large volume development (discussed below) resulted in less complete mixing during April 1969 and November 1970. In past years, incomplete mixing has given rise to temporary biogenic meromixis in Lawrence (Wetzel et al., 1971). Following spring overturn, Lawrence quickly became thermally stratified with a well defined metalimnion between 5 and 6 meters. During the study period, maximum temperatures at I m (24-26 C) were reached during July and August.

Temperature data for Wintergreen (Figure 5) are complicated by the change from station A (4 m max. depth) to Station B (6.3 $\mathrm{m} \max$. depth) in October 1970. At Station $A$, mixing in the fall was complete throughout the 


\begin{abstract}
Figure 4. (A) Water level (B) Temperature isopleths (C) Temperature at $1 \mathrm{~m}$ depth and (D) Secchi disc transparency in Lawrence Lake from July 1969 to May 1971. Opaque area represents ice cover to scale.
\end{abstract}


LAWRENCE
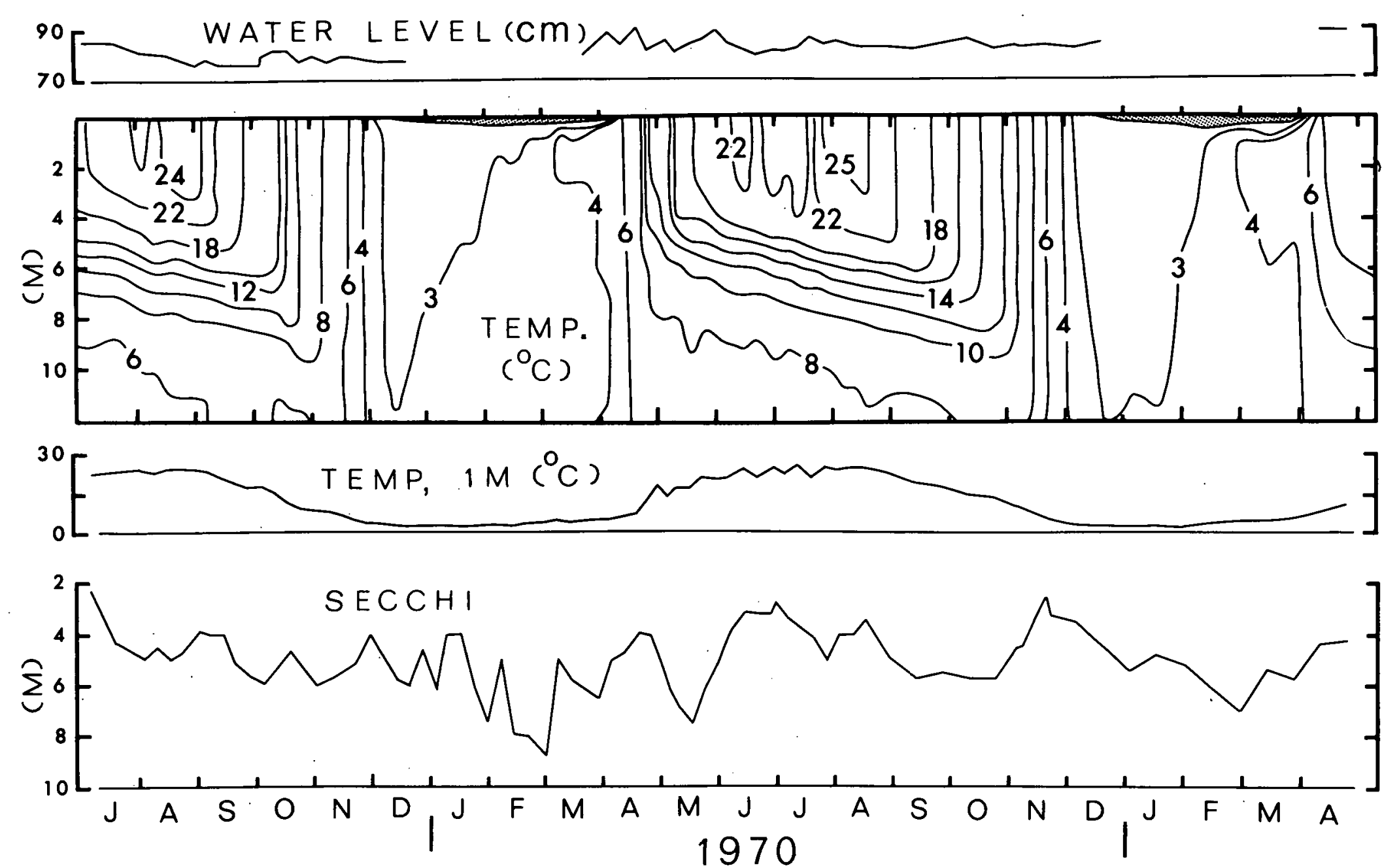
Figure 5. (A) Rainfall (B) Water level (C) Secchi disc transparency (D) Temperature at $1 \mathrm{~m}$ depth and (E) Temperature isopleths in Wintergreen Lake from July 1969 to May 1971. Opaque area represents ice cover to scale. 
WINTERGREEN
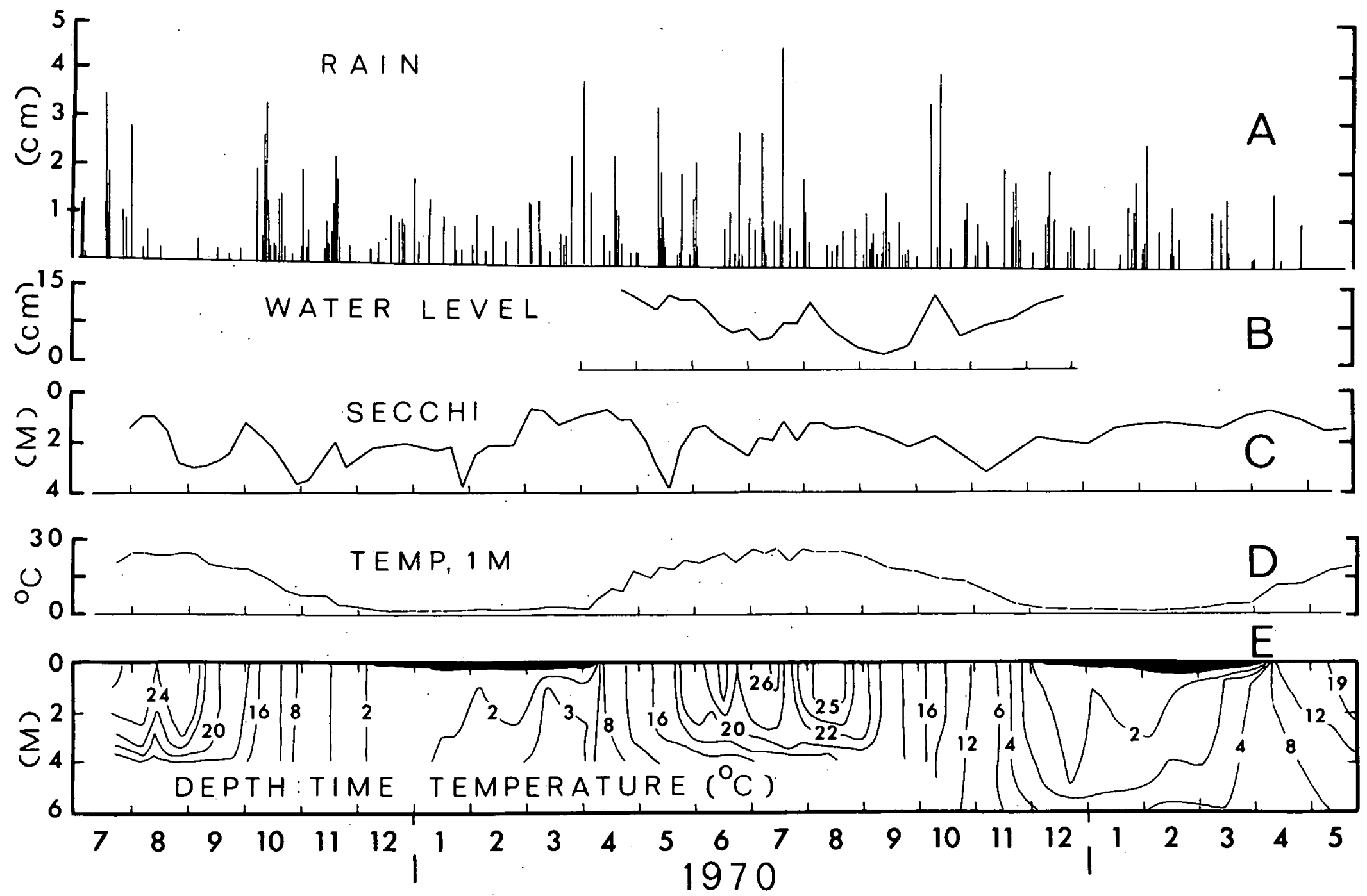
water column for nearly two months prior to complete mixing in the deeper waters, which was of three weeks duration. Data for both years illustrate Wintergreen was second-order and dimictic but because of its lesser depth, Wintergreen became thermally stratified more slowly with a poorly developed metalimnion between 4 and 5 meters. Maximum temperatures at one meter $\left(26^{\circ} \mathrm{C}\right)$ occurred during July and August and were sustained longer than maximum temperatures at one meter in Lawrence.

Changes in Secchi disc transparency in Lawrence were in close agreement with changes in ${ }^{14} \mathrm{C}$ productivity (Figure 6). From May to september 1970, the inverse of Secchi disc transparency was highly correlated with epilimnetic ${ }^{14} \mathrm{C}$ productivity in Lawrence $(r=0.87, \mathrm{~N}=13)$. This correlation did not extend to periods of overturn when large amounts of bottom sediment are resuspended from the benthos (Rich, 1970a). Similar decreases in transparency occurred in Wintergreen prior to fall overturn (August-September) and ice melt (February-March) when massive blooms of Aphanizomenon and chlamydomonad $\mu$-flagellates occurred respectively. Cyanophyta densities during AugustSeptember 1969 and other observations prior to this period (G. W. Saunders, Pers. comm.) showed blooms of blue green algae found during the fall 1970 were not present in 1969; hence the lack of decreases in Secchi disc transparency during August-September 1969. 
Figure 6. Isopoleths of dissolved oxygen (mg/l), $\mathrm{pH}$, and ${ }^{14} \mathrm{C}$ productivity (mg C/m $\mathrm{m}^{3} / \mathrm{da}$ ) in Lawrence Lake from July 1969 to May 1971. Opaque areas represent ice cover to scale. 

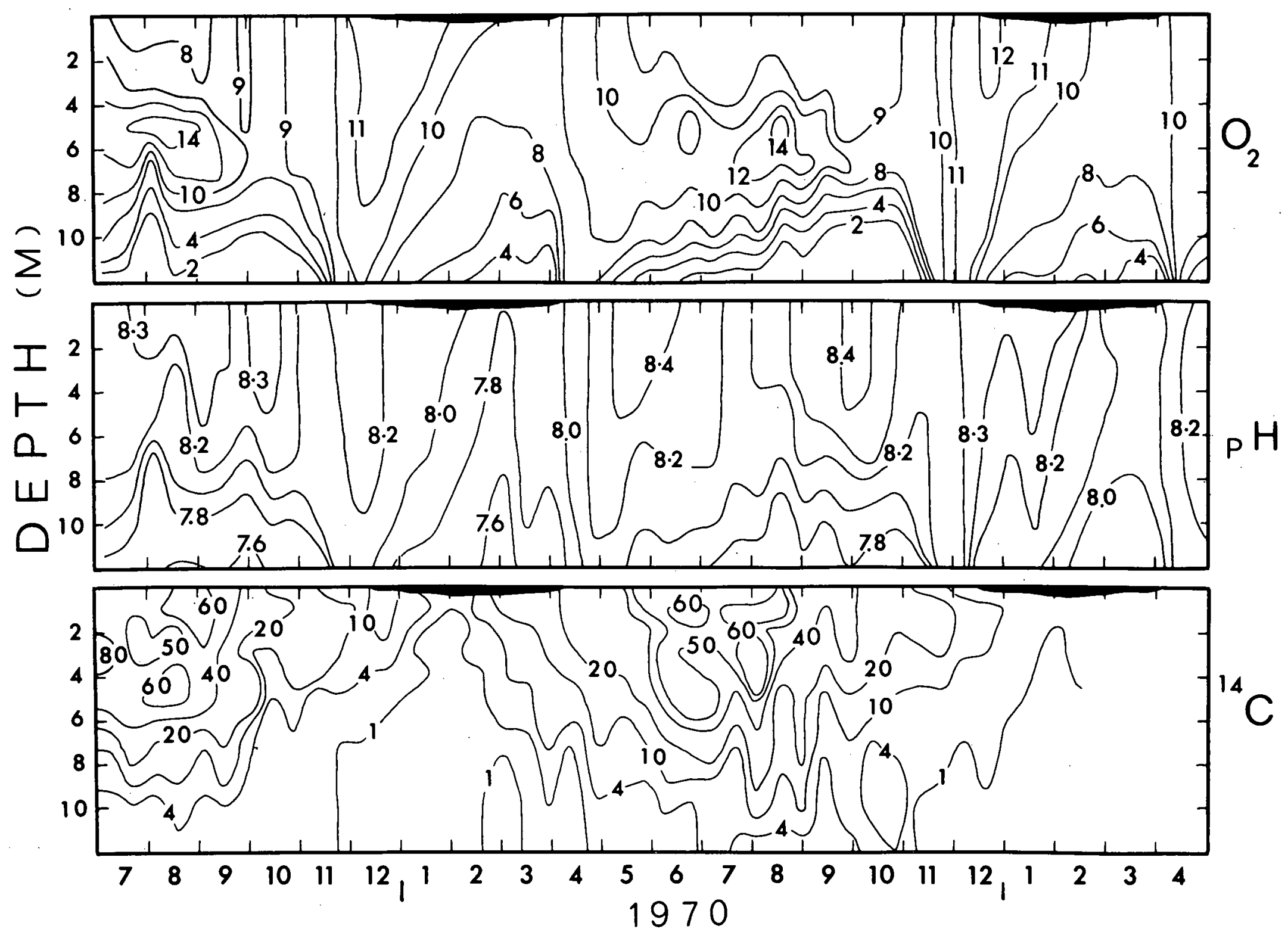
Periods of maximum epilimnetic oxygen concentrations (14 mg/1) in Lawrence coincided closely in time and depth with ${ }^{14} \mathrm{C}$ productivity maxima (Figure 6 ). Periods of minimum hypolimnetic oxygen concentration (to $0.06 \mathrm{mg} / \mathrm{l}$ ) in october coincide closely with minimum hypolimnetic $\mathrm{pH}$ values (to 7.53 units). Although complete oxygen data are not available for wintergreen, periodic winkler determinations indicated anoxia below $5 \mathrm{~m}$ depth most of the year. The $\mathrm{pH}$ data (Figure 7) illustrate $\mathrm{pH}$ decreased progressively at 5 meters after fall overturn and reached minimum levels (7.2) just prior to spring overturn.

2. Macrophytes, Zooplankton, Phytoplankton

Excepting the submerged marl bench in Lawrence Lake and sandy east shore of Wintergreen, dense beds of submerged macrophytes have colonized the entire substratum to the depth of 18 light penetration in both lakes (about $7 \mathrm{~m}$ in Lawrence and $3 \mathrm{~m}$ in Wintergreen). In Lawrence, $42 \%$ of the surface area supports submerged macrophytes. Nearly $79 \%$ of the macrophytic biomass consists of the water bulrush (Scirpus subterminalis Torr.) and $12 \%$ of two species of Chara (Rich, Wetzel and Thuy, 1971). In Wintergreen, about $72 \%$ of the basin is colonized by dense beds of submerged Ceratophyllum demersum L., Myriophyllum exalbescens Fernald, Potamogeton foliosus Raf., P. pectinatus L., Najas flexilis (Willd.) Rostk. and Schmidt and emergent 
Figure 7. Isopleths of $\mathrm{pH}$ at Station B in Wintergreen Lake from October 1970 to May 1971. Opaque area represents ice cover to scale. 


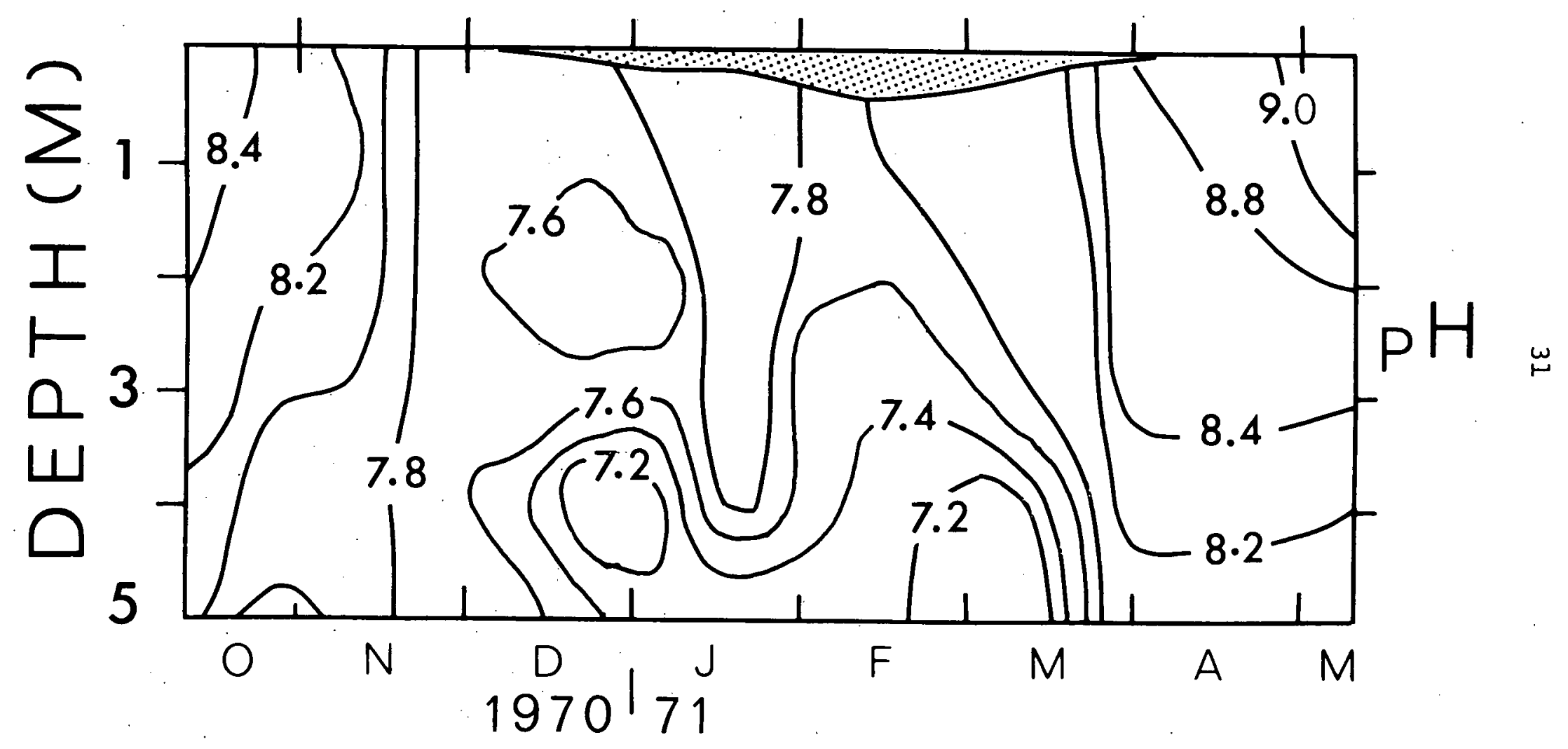


Nuphar advena Aiton. Only $47 \%$ of the water volume does not contact submerged or floating macrophytes in Wintergreen.

As part of a continuing intensive investigation of phytoplanktonic, epiphytic algal, benthic and bacterial metabolism in Lawrence (Allen, 1971; Rich, 1970a; Rich et al., 1971; Miller, 1971; Wetzel et al., 1971), submersed macrophytes were shown to be responsible for $48 \%$ of the annual photosynthetic carbon fixation by comparison with fixation of the phytoplanktonic and epiphytic algal floras. These values indicate macrophytic plants and their associated littoral microflora dominate autotrophic productivity in both lakes considered here and likely in many hardwater lakes of shallow to intermediate depth (Wetzel, 1964b; Davies, 1970; Allen, 1971; Wetzel and Allen, 1971; Wetzel et al., 1971).

Other than a study of population dynamics of natural Chydorid populations in the littoral zone of Lawrence (Keen, 1970) and pelagic studies of Leptodora in 1969 (Cummins and Rowe, unpubl.), zooplankton of Lawrence and Wintergreen has not been studied extensively. Previous studies of the fish populations (Fetterolf, 1952) and insect bottom fauna (Scheibner, 1958) in Wintergreen Lake have been made. Abundant populations of Daphnia galeata mendotae and $\underline{D}$. pulex occasionally appear in June and Leptodora was found at $0.1 / 1$ iter from June to August. Casual observations throughout the year indicate most 
crustacean zooplankton in Lawrence Lake are copepods found largely among the macrophytes and near the bottom. Zooplankton in wintergreen is generally much more abundant than zooplankton in Lawrence Lake (to over 1500 individuals/liter). Smaller cladocerans (Alona, Chydorus) predominate during the colder months but occasional high densities of Daphnia galeata mendotae and Bosmina longispina have appeared, usually in early summer. In July and August, Chaoborus larva often appear in high numbers at night.

Phytoplankton in Lawrence and Wintergreen lakes may be readily distinguished on the bases of mean size and percentage composition of the total algal volume by members of the three major phyla (Figure 13; Table 4). In general, blue-green algae and $\mu$-flagellate green algae predominated at $1 \mathrm{~m}$ depth in Lawrence producing standing crops $\left(\mu^{3} / 1\right)$ about $1 / 10$ th to $1 / 100$ th those present in wintergreen during the same period. Phytoplankton in Wintergreen underwent marked succession beginning with small flagellated Cryptophyta and Chlorophyta present in high densities under the ice (perhaps explaining the name Wintergreen) .

Wintergreen Lake is a part of the Michigan State University Bird Sanctuary and is a stopping point for some 10,000 Canada geese (Branta canadensis interior Linn.) and similar numbers of smaller waterfowl in their annual 
migration to and from Canada. The lake also serves as a permanent home for a resident flock of Canada geese established by Mr. W. K. Kellogg in 1928 (Powell, 1956). By contrast, Lawrence Lake is rarely visited by waterfowl, probably as a consequence of less available food and greater hunting pressure. Nutrients and dissolved organic matter contributed by these waterfowl (Manny and Johnson, in prep.) and differences in watershed character of Lawrence and Wintergreen emphasize the influencial role in lake productivity played by factors outside lakes. These factors are believed to be a primary cause of measurable differences in relative productivity discussed below. 


\section{INORGANIC NITROGEN AND PHOSPHORUS INTERACTIONS}

\section{A. Hypolimnetic Transformations}

Many interrelated factors affect nitrogen transformations in lake metabolism. Important physical factors include the character of the watershed, basin morphometry and mean depth (Thienemann, 1927), duration of winter and summer stagnation (Yoshimura, 1935; Ricker, 1937; Hutchinson, 1938; Rawson, 1939; Deevey, 1955) and epilimnetic temperature and light. Lawrence and Wintergreen lakes differ greatly in mean depth and watershed character but are similar in light energy received and epilimnetic temperatures attained. Differences in aerial and allochthonous contributions between the two lakes are probably more important than morphometric and thermal characteristics but of equal or lesser importance than duration of hypolimnetic stagnation and nutrient redistribution during overturn.

Partial suppression of vernal circulation in small, deep lakes is not unusual (Hutchinson, 1958:488) and may be expected to result initially in decreased epilimnetic productivity and higher initial hypolimnetic 
nutrient concentrations the following season. Temporary meromixis occurred in Lawrence after spring overturn 1968 and 1969, however, data are not available to evaluate whether higher than normal concentrations of nitrate and ammonia appeared in the hypolimnion.

Data at 1 meter depth indicate ammonia decreased at about the same rate in both lakes during March to May 1970 and 1971 while nitrate continued to accumulate (Figures 8 and 9). Because ammonia levels dropped markedly before nitrate levels both years, it is likely ammonia is more readily utilized by phytoplankton under the ice in early spring.

\section{Lawrence Lake Nitrogen}

Nitrogen changes throughout the water column in many lakes are influenced by the formation and breakdown of a thin layer of oxidized sediments--the oxidized microzone (Mortimer, 1941, 1942). Because an oxidized microzone can regulate the release of regenerated nutrients into overlying waters, possible effects of an oxidized. microzone in Lawrence and Wintergreen lakes are discussed. The discussion is hypothetical; no measurements were made to confirm the existence of an oxidized microzone in either lake.

An oxidized microzone is created by resuspension of surface sediments during overturn (Mortimer, 1941, 1942, 1969; Vallentyne, 1955; Gorham, 1958; Hayes et a1.. 
Figure 8. Annual cycles of (A) Nitrate (left) and ammonia (right) in $\mathrm{mg} / \mathrm{l}$

(B) Total phosphorus in filtered (shaded area) and unfiltered water $(\mu \mathrm{g} / 1)$ (C) Sediment temperature minus the temperature of water at $12 \mathrm{~m}$ depth $\left({ }^{\circ} \mathrm{C}\right)$ and $(D)$ Conductivity (umhos $\left.a 25 \mathrm{C}\right), \mathrm{pH}$ and dissolved oxygen concentrations $(\mathrm{mg} / \mathrm{l})$ at $12 \mathrm{~m}$ depth in Lawrence Lake from July 1969 to May 1971. 

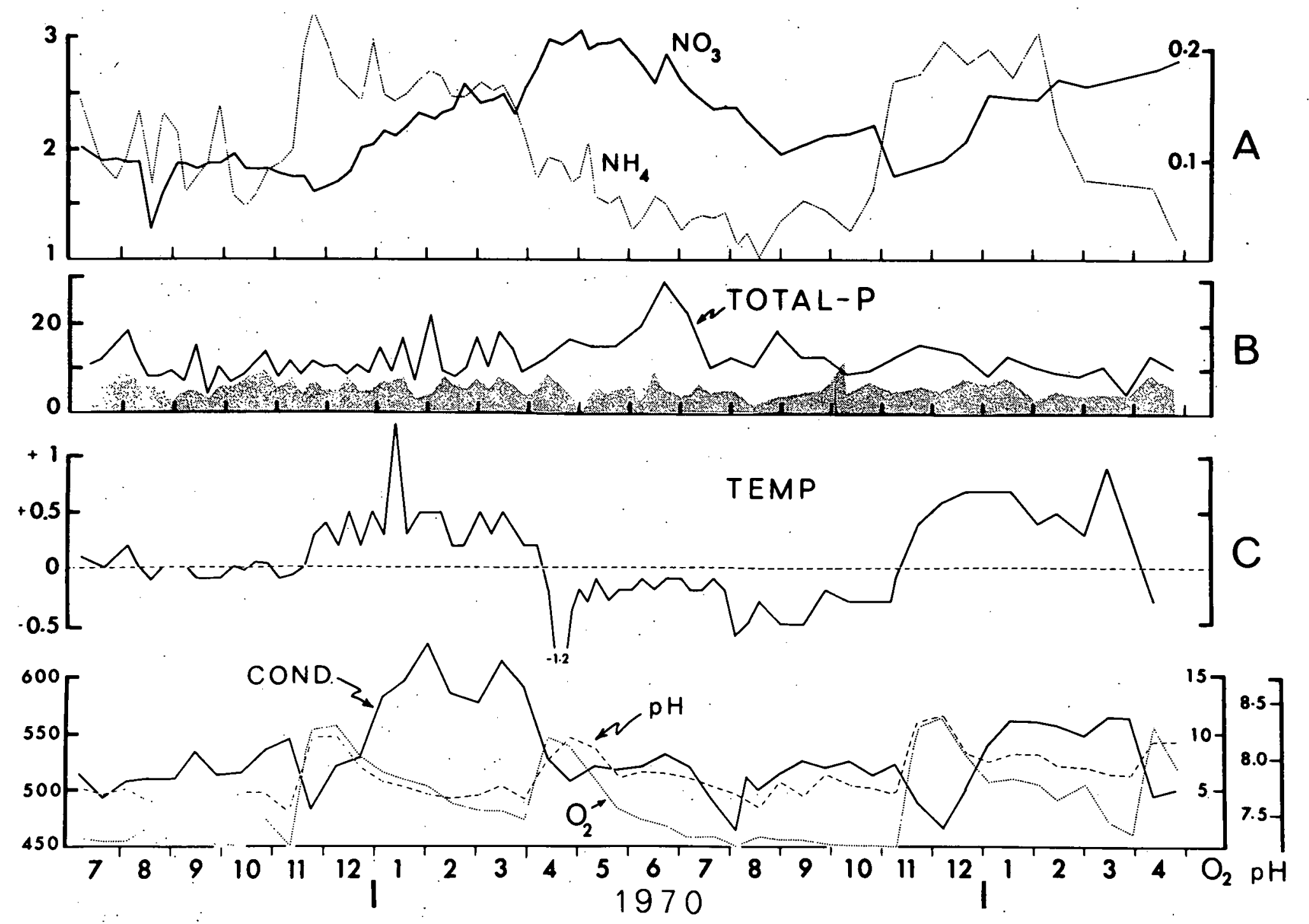
Figure 9. Annual cycles in $\mathrm{mg} / \mathrm{l}$ of (A) Nitrate and ammonia (B) Total phosphorus in filtered (shaded area) and unfiltered water during 1969-70 (C) Total phosphorus in unfiltered water during 1955-57 and (D) Sediment temperature minus water temperature at $5 \mathrm{~m}$ depth $\left({ }^{\circ} \mathrm{C}\right)$ in Wintergreen Lake from August 1969 to April 1971. Unpublished phosphorus data for 1955-57 were provided by Dr. R. C. Ball of Michigan State University. 

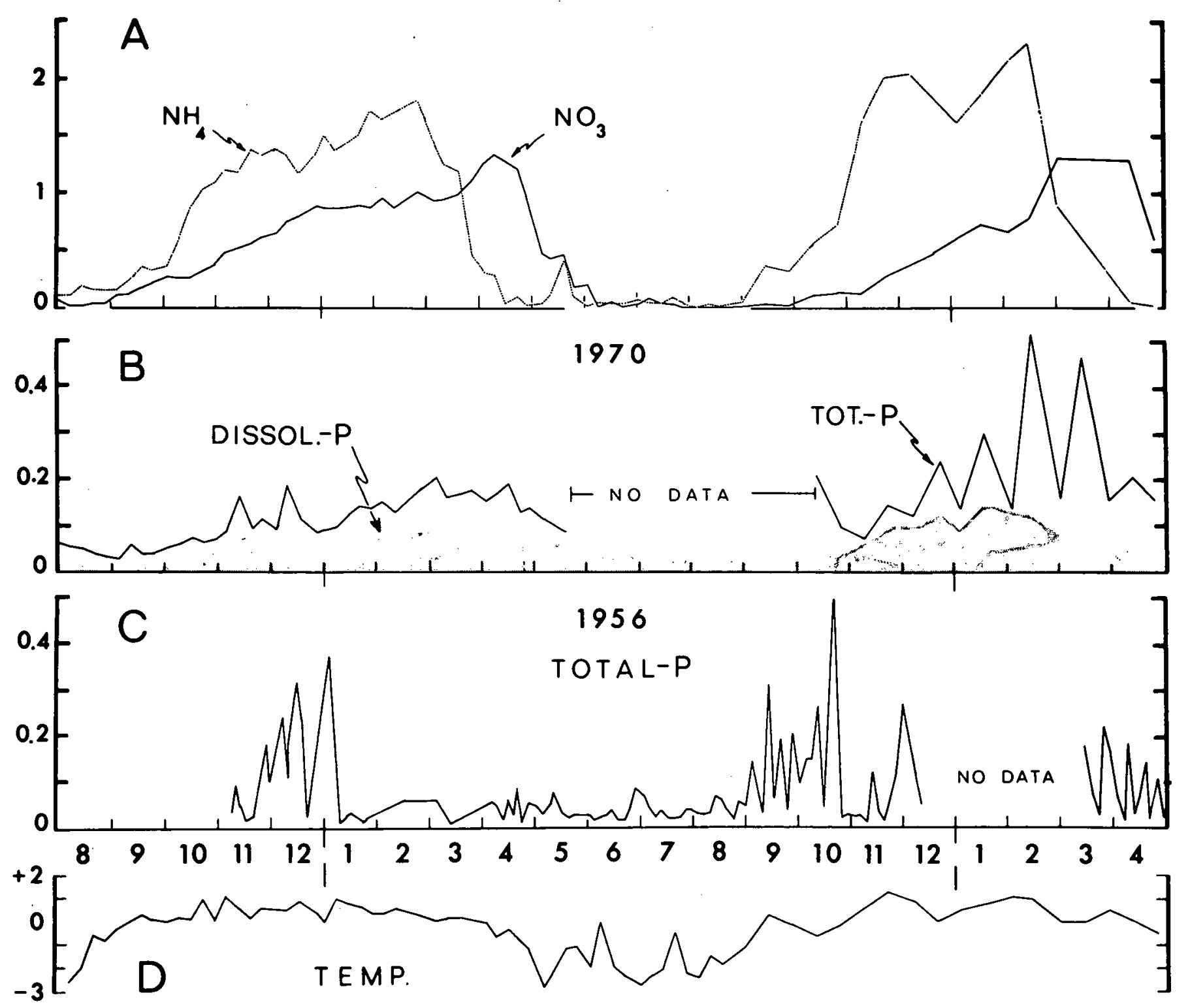
1958; Rich, 1970a). As bacteria deplete oxygen in the sediments after overturn, oxygen depletion in the overlying waters begins (Kusnetzow, 1935). At this time, a thin skin of oxidized sediments--the microzone--produces oxidized ions which counter the upward diffusion of reduced ions and cause them to be precipitated, assimilated or adsorbed in clearly defined strata beneath the upper few millimeters of sediment. As hypolimnetic oxygen, $\mathrm{pH}$, and redox potential decrease, reducing bacteria generate localized spots of reduced sediments in the microzone around bits of organic matter fallen from above. This produces a spotty or mottled appearance on the sediment surface. As more organic matter reaches the sediments, the microzone is eventually destroyed from above and below. Thereafter, reduced ions may diffuse freely into the water column aided by hypolimnetic currents (Hutchinson, 1941; McCarter et al., 1952) and eddy diffusion currents, but restricted by critical pH, redox and density gradients (Mortimer, 1941, 1942). Seiches may feature in nutrient movements of larger lakes (Hutchinson, 1957; Mortimer, 1969).

Oxygen data from Lawrence Lake indicate hypolimnetic concentrations during spring mixing in April 1970 would have been adequate to form an oxidized microzone (Figure 8). Increased conductivity at $12 \mathrm{~m}$ during May and June 1970 (Figure 8) relative to that which 
developed the previous winter suggest a microzone would have disappeared more rapidly after fall overturn 1969 than after spring overturn 1970. Mortimer (1942) observed reestablishment of an oxidized microzone after fall overturn in productive Esthwaite water was inhibited by rapid oxygen utilization in the oxidation of summer accumulations of Fes. These events probably do not occur in Lawrence Lake because fall mixing is usually very complete and FeS has never been observed (R. G. Wetzel, personal communication). Sumuer accumulations of Fes are likely involved in similar events in Wintergreen after fall overturn, however, no data are available.

The absence of oxygen depletion below $2 \mathrm{mg} / \mathrm{l}$ during either winter during the study and the rapid rate of oxygen depletion during June 1970 (Figure 8) suggest a microzone would have disappeared more rapidly or to a greater extent during summer stagnation than during winter stagnation in Lawrence Lake. Lack of an oxidized microzone may be inferred from physical examination of surface sediments for the presence of black Fes deposits, a redox potential less than $200 \mathrm{mv}$ or the presence of ferrous iron in overlying waters (Mortimer, 1941-1942).

Absence of the microzone may also be hypothesized from hypolimnetic oxygen concentrations less than 0.5 mg/l (Mortimer, 1941-1942). This condition existed in Lawrence from June to November 1969 and August to 
November 1970 but not during either winter stagnation period. On this basis, an oxidized microzone may have formed to various depths in the sediments during either overturn in Lawrence Lake, but breakdown would have occurred to a greater extent during summer stagnation than during winter stagnation.

Rapid increases in nitrate and nitrite appeared near the sediments during December to January 1970-71 (Figure 10). During this period, warmest temperatures in the lake were present in the sediments (Figure 8C). These observations suggest the sediments were a site of active metabolism in Lawrence Lake during the winter. Temperature differences of $1-2^{\circ} \mathrm{C}$ (Figure $8 \mathrm{C}$ ) between sediments and overlying water may also have been adequate to warm the overlying waters enough to generate convection and eddy diffusion currents. If so, reduced ions emerging from the sediments would have been carried into the water column much more rapidly than they could move by molecular diffusion (Mortimer 1941-1942). Such currents are probably absent during the summer stagnation period because the sediments are colder than overlying waters during the summer months (Figures $8 \mathrm{C}$ and 9D).

$$
\text { Mortimer (1941-1942) and Hutchinson (1941) }
$$

characterized three stages in seasonal cycles of hypolimnetic oxygen depletion and redox potential in euthrophic lakes which regulated nutrient release from 
Figure 10. Isopleths of nitrate $(\mathrm{mg} / \mathrm{l})$, nitrite $(\mu \mathrm{g} / \mathrm{l})$ and ammonia $(\mu \mathrm{g} / 1)$ in Lawrence Lake from August 1970 to April 1971. Opaque area represents ice cover to scale. 

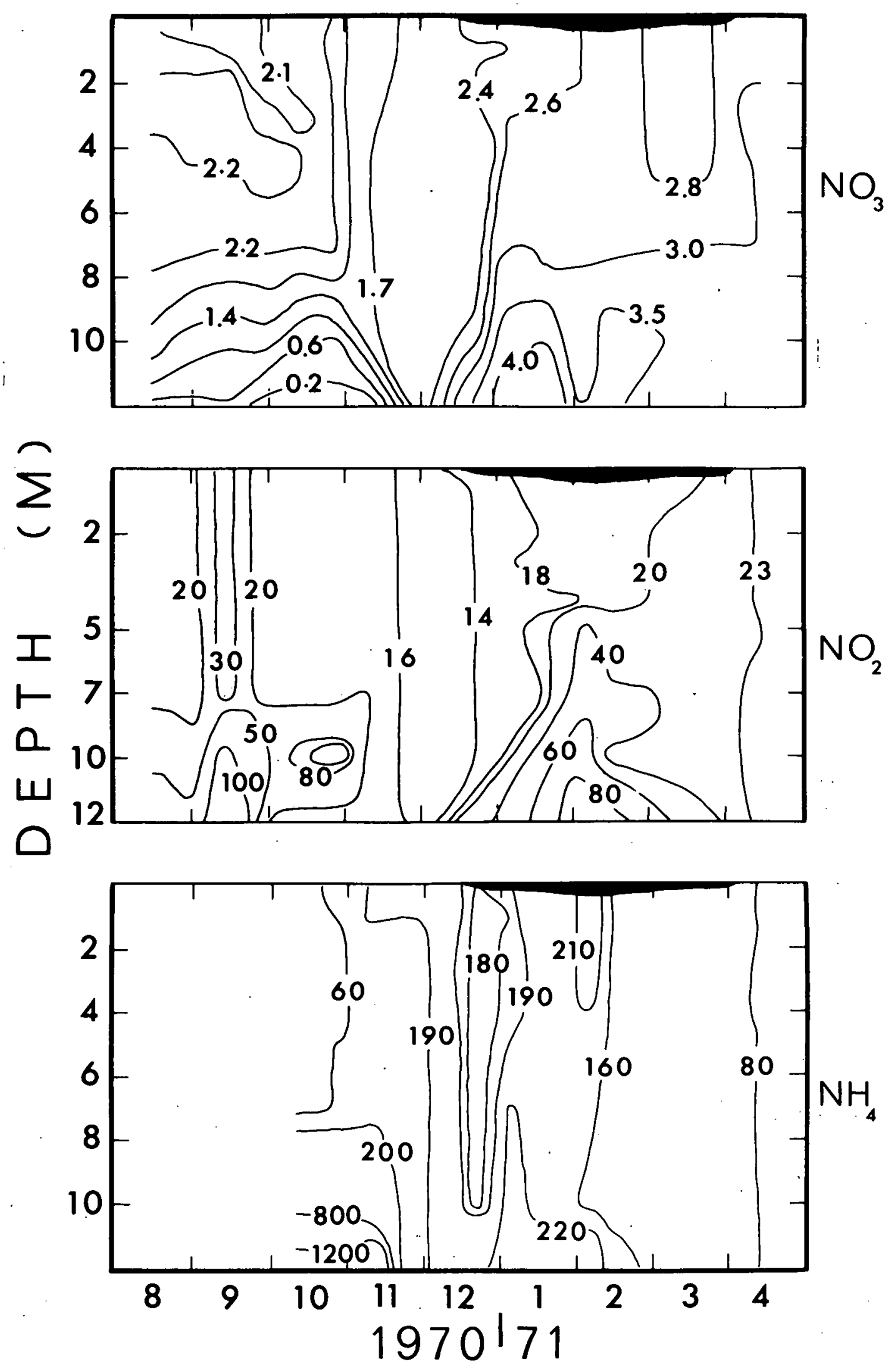
the sediments. Stage I began after overturn and was characterized by rapid reduction of hypolimnetic oxygen to less than $2 \mathrm{mg} / \mathrm{l}$ and small increases in alkalinity, conductivity and ferrous iron. Dissolved oxygen, alkalinity and conductivity underwent similar changes during May and December 1970 at $12 \mathrm{~m}$ depth in Lawrence Lake.

Stage II was initiated by a rapid reduction in redox potential and slower decreases in oxygen concentration above the sediments to $250 \mathrm{mv}$ and $0.5 \mathrm{mg} / 1 \mathrm{re-}$ spectively. Rapid increases in alkalinity, conductivity, Fe, $\mathrm{P}$ and turbidity followed. Ammonia production during this stage was of even greater magnitude than nitrate reduction which was, by then, nearly complete near the sediments. These changes may have occurred during August and September 1970 in Lawrence Lake.

Stage III was characterized by slower evolution of solutes into overlying waters with subsequent accumulation of nitrate and ammonia throughout the water column under ice cover. This stage was evident after fall overturn in the nitrate data in Lawrence Lake (Figures 8 and 10).

Prior to overturn in November 1970 , nitrate concentrations between 7 and $12 \mathrm{~m}$ had decreased nearly 10fold (Figure 10). Concurrent increases in nitrite and ammonia in this stratum clearly suggest nitrate reduction 
occurred and resulted in ammonia accumulations at $12 \mathrm{~m}$. Reduction seems to have been nearly quantitative but a difference between $\mathrm{NO}_{2}+\mathrm{NH}_{4}$ in the 7-12 $\mathrm{m}$ stratum $(1400 \mu \mathrm{g} / \mathrm{l})$ and nitrate concentrations prior to August (> $2000 \mu \mathrm{g} / \mathrm{l}$ ) may reflect ammonia loss during filtration. Unless samples are acidified before filtration using HA Millipore filters, ammonia may be lost as gas (A. Otsuki, personal communication). In this work, less than onehalf atmosphere vacuum and glass fiber filters were used. Evidence of nitrate reduction may also be drawn from hypolimnetic oxygen and $\mathrm{pH}$ data at $12 \mathrm{~m}$ (Figure 6). Nitrate reducing bacteria Pseudomonas denitrificans and Denitrobacillus licheniformis are readily suppressed by free oxygen (Thimann, 1963). Because oxygen concentrations and $\mathrm{pH}$ were at minimal levels while necessary organic substrates (Thimann, 1963) were likely present in ample amounts prior to fall overturn, conditions were likely optimal for nitrate reduction.

After fall overturn, nitrification likely

occurred. Increased nitrate between 10-12 $\mathrm{m}$ in January (Figure 10) coincided with rapidly decreasing ammonia concentrations and increased nitrite below $5 \mathrm{~m}$. Oxygen concentrations and $\mathrm{pH}$ data for the January-February period 1971 indicate aerobic, basic conditions prevailed which would have encouraged the growth of Nitrosomonas and Nitrobacter (Figure 6). These bacteria nitrify 
ammonia and nitrite optimally between $\mathrm{pH} 8.5$ and 8.8 but function at $80 \%$ efficiency between $\mathrm{pH} 8.0$ and 8.5 (Thimann, 1963). Because nitrate rapidly accumulated between 10 and $12 \mathrm{~m}$, nitrification was likely more rapid after overturn than the reverse process prior to overturn. As nitrification progressed, nitrate, nitrite and ammonia increased below $5 \mathrm{~m}$. Above this depth after mid-February, biological utilization likely prevented further $\mathrm{NH}_{4}$ accumulation (Figures 8,14 ).

\section{Wintergreen Lake Nitrogen}

Wintergreen Lake became anaerobic below $5 \mathrm{~m}$ within four weeks after spring overturn and was periodically anaerobic below $2.5 \mathrm{~m}$ within six weeks after spring overturn. Hence, for most of the year and particularly in late summer, hypolimnetic conditions in Wintergreen were favorable for regeneration of ammonia. Possibly some nitrate was produced. It is therefore unclear why ammonia and nitrate were essentially undetectable at $1 \mathrm{~m}$ depth at Station A from June to August 1970 (Figure 9). One explanation is metalimnetic thermal stratification between 3 and $4 \mathrm{~m}$ was adequate to prevent transport of ammonia or nitrate to $1 \mathrm{~m}$ depth. Another is nitrogen reaching $1 \mathrm{~m}$ depth was completely utilized by dense algal populations that were increasing continuously during this period (Figure 18). Lastly, the ammonia may have evolved as gas. The temperature isopleths (Figure 5) favor the first 
explanation. The latter explanation would have been most likely when the water was warmest, well mixed, and alkaline.

More complete data at Station B indicate nitrate increased continuously at all depths under ice cover (Figure 11). After brief accumulation between 4 and; $5 \mathrm{~m}$ in January, nitrite also increased at all depths. Nitrification of ammonia apparently equaled ammonia production from the sediments until mid-January. Thereafter, ammonia was rapidly evolved from the sediments and accumulated between 3 and $5 \mathrm{~m}$.

3. Phosphorus in Lawrence and Wintergreen Lakes

Phosphorus concentrations in Lawrence and Wintergreen lakes clearly differed. Total dissolved phosphorus (TDP) in Lawrence very rarely exceeded $18 \mu \mathrm{g} / \mathrm{l}$ at any depth whereas in wintergreen, TDP was nearly always present in concentrations greater than $20 \mu \mathrm{g} / 1$ (Figure 9). TDP increased to $300 \mu \mathrm{g} / 1$ at $5 \mathrm{~m}$ in Wintergreen under ice cover (Figure 11).

Seasonal variation in TDP at $1 \mathrm{~m}$ in Lawrence was evident on only one occasion. During overturn $(7$ November 1970), TDP doubled in concentration at $1 \mathrm{~m}$ for less than two days (Figure $8 \mathrm{~B}$ ). In wintergreen, TDP at $1 \mathrm{~m}$ increased 7-fold to $140 \mathrm{\mu g} / \mathrm{l}$ under the ice in January (Figure 11). Isopleth values in Figure 11 suggest TDP 
Figure 11. Isopleths of nitrate (mg/1), nitrite ( $\mu \mathrm{g} / 1$ ), ammonia (mg/l) and total dissolved phosphorus $(\mu \mathrm{g} / 1)$ in Wintergreen Lake from October 1970 to April 1971. 


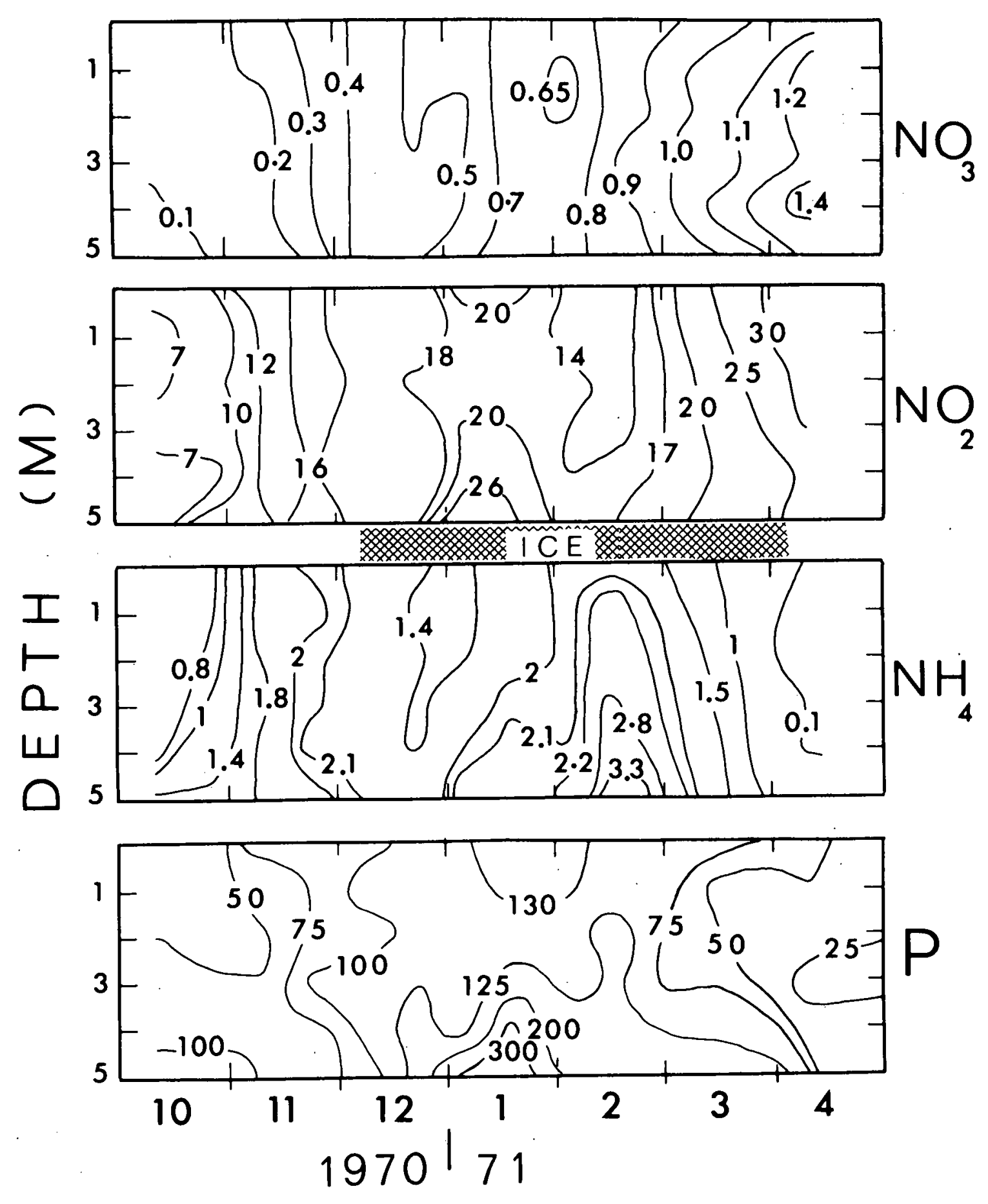


regeneration in wintergreen is likely regulated by many of the same factors as ammonia regeneration; coincident with $\mathrm{pH}$ decreases to 7.2 (Figure 7), TDP began to accumulate between 4 and $5 \mathrm{~m}$ as did ammonia. During February and April 1971, TDP decreased quickly at all depths until only minimal concentrations (for Wintergreen) remained.

Total (raw water) phosphorus (TP) at $1 \mathrm{~m}$ underwent 2 -fold seasonal variation in Lawrence reaching maximum values in early August, early February and late June --the period of maximum photosynthesis (Figure 6). In Wintergreen, TP followed changes in TDP closely. Maximum values were reached during February and March (Figure 9B) during the spring phytoplankton bloom. Analyses are not complete for June to November 1970 .

Comparison of TP analyses by Dr. R. C. Ball on surface water collected during 1955-57 near the outlet of Wintergreen wịth values at 1 m during 1970 revealed maximum and minimum values have remained nearly the same for 16 years (Figure 9). Seasonal periodicity of the maxima vary considerably from year to year. Additional data are needed to evaluate whether the more extended duration of high TP concentrations during 1969-1971 relative to 19551957 indicate TP concentrations have increased in absolute terms since 1955 .

Comparisons made above suggest pelagic phosphorus transformation in Lawrence Lake are damped by one or more 
mechanisms not operating in Wintergreen Lake. A possible mechanism is postulated below (cf. Discussion) and evaluated with respect to differences in productivity exemplified by Lawrence and Wintergreen lakes.

\section{B. Allochthonous Nitrogen and Phosphorus}

1. Aerial Nitrogen and

Phosphorus

Aerial and allochthonous inputs of nitrogen and phosphorus are being increasingly recognized as major nutrient sources to small (Barica, 1970) and large (Stephenson and Ball, 1969) lakes. Available data indicate nitrogen and phosphorus from these sources were of major importance to Wintergreen Lake.

Nitrate, ammonia and total phosphorus were measured in newly fallen snow and month-old ice on Wintergreen Lake on 18 January 1971. Concentrations $(\mu \mathrm{g} / 1)$ in the snow were: nitrate 1124; nitrite 16.3; ammonia 724 and phosphorus 263. In the ice concentrations were somewhat less. For example $(\mu \mathrm{g} / 1)$ : nitrate 435 ; nitrite 8; ammonia 419 and phosphorus 108. These values are surprisingly high but within ranges reported in the literature, i.e., in $\mu \mathrm{g} / 1$ : nitrate 200-3000; ammonia 100-1600; and phosphorus 10-1110 (Dahr and Ram, 1933; Fisher et al., 1968; Bozniak and Kennedy, 1968; Barica, 1970; Taylor et $\underline{\text { al. }}$, 1971). Because ice and snow melt when nitrogen and phosphorus concentrations are high in the surface 
waters, nitrogen and phosphorus contributed by ice and snow have largely been ignored in the past. This will likely not be the case much longer because Deevey (1970, 1971) has now shown aerial contributions of ammonia and nitrate are the major source to an entire watershed in New Hampshire.

Aerial contributions of nitrogen and phosphorus by waterfowl are believed to be the driving force behind the high sustained productivity in Wintergreen Lake. Data from Sylvester and Anderson (1964) showed single fresh and aged wildfowl excreta (approximately 1-2 g dry weight) contained on the average, $1.43 \mathrm{mg} \mathrm{NO}{ }_{3}, 10.3 \mathrm{mg}$ organic nitrogen and $0.91 \mathrm{mg}$ total phosphorus. Using an average winter density of 3.5 excreta $/ \mathrm{m}^{2}$ (Manny and Johnson, in prep.), nutrient input per $\mathrm{m}^{2}$ during the winter alone would be $5.0 \mathrm{mg} \mathrm{NO}_{3}$ ' $36.1 \mathrm{mg}$ organic nitrogen and $3.18 \mathrm{mg}$ phosphorus. Excreta from domestic waterfowl, which number more than 300 all year on wintergreen, are even higher in nitrogen and phosphorus content (Sanderson, 1953). Quantification of the input by migratory waterfowl to Wintergreen awaits analysis of several hundred excreta collected during January 1971 when some 400 late migrating Canada geese spent two days on the ice before flying south (Manny and Johnson, in prep.). These birds contributed 3.0 droppings per $\mathrm{m}^{2}$ over a $3000 \mathrm{~m}^{2}$ area during 4840 goose-use hours. Observations in March 1971 revealed about 3-4 droppings per $\mathrm{m}^{2}$ over the entire lake surface. No estimate was made of nutrients contributed 
by the resident flock of some 100 Canada geese and 200 ducks. These birds receive a rich diet of corn provided by sanctuary personnel at lakeside.

\section{Lawrence Lake}

Inorganic nitrogen entered Lawrence Lake from six visible sources during spring run-off (cf. Figure 30, discussed below). Analyses of filtered water from each source indicated water entering from the north marsh was highest in nitrate and equal in ammonia to water originating in the northeast marsh. Nitrate concentrations at stream Station A on 29 April 1971 were $8.76 \mathrm{mg} / 1$. Nitrate concentrations greater than $5 \mathrm{mg} / 1$ in unpolluted water are generally found in ground waters receiving drainage from barnyards or soils fertilized repeatedly (Hem, 1959; Olsen et al., 1968). But $8.76 \mathrm{mg} / 1$ would not be regarded as excessive if present only in the spring when nitrate in stream waters is sharply higher (Fisher et al., 1968; Taylor et al., 1970). Because cultivation of the surrounding watershed had not begun prior to 21 April 1971, high nitrate concentrations were not caused by direct fertilizer run-off. More likely, nitrate was generated in the surrounding soils during winter nitrification by Nitrosomonas and Nitrobacter of fertilizers applied the previous year. Additional analyses in progress will identify and characterize allochthonous inorganic nitrogen entering Lawrence Lake. Data from April 1971 confirm that spring run-off 
was a source of high nitrate concentrations. No measurements were made of phosphorus entering the lake.

\section{Wintergreen Lake}

During the study, Wintergreen received nitrogen and phosphorus enrichment from five visible sources. In order of importance they were: migrating Canada geese and ducks; resident geese and ducks; a dairy feed-lot effluent; domestic wastes from a public school and fertilizer run-off from nearby cornfields. Quantitative data on these sources is limited to one four-week survey conducted prior to and after ice-off in spring 1970 (Table 3).

A continuous flow of feed-lot effluent (approx. 2 liter/min) entered the Dairy Lagoon (Figure 12) throughout the study period. During periods of high run-off, nitrogen and phosphorus entered the lake from this lagoon. The School Lagoon (Figure 12) received a continuous flow of domestic wastes of comparable volume from a nearby public school. Nitrogen and phosphorus from this lagoon likewise entered the lake during periods of high run-off. Both lagoons were likely more important nutrient sources in past years when they were used more extensively. Plans are presently being laid to prevent either effluent from entering the lake in the future.

The above sources were likely of greater relative importance than fertilizer run-off from adjacent cornfields, 
Table 3. Nitrogen and phosphorus $\left(\mu \mathrm{g} \mathrm{I}^{-1}\right.$ ) present at four stations in Wintergreen Lake just prior to and immediately following ice-out on 6 April 1970.

\begin{tabular}{|c|c|c|c|c|c|c|c|c|}
\hline Date & Station & $\begin{array}{c}\text { Dissolved- } \\
\text { P }\end{array}$ & $\underset{P}{\text { Particulate- }}$ & $\begin{array}{l}\text { Total- } \\
\mathrm{P}^{-}\end{array}$ & $\mathrm{NO}_{3}-\mathrm{N}$ & $\mathrm{NO}_{2}-\mathrm{N}$ & $\mathrm{NH}_{4}-\mathrm{N}$ & $\underset{N}{\operatorname{Total}-}$ \\
\hline $3 / 18 / 70$ & $\begin{array}{c}\text { C } \\
D \\
\text { A } \\
\text { Outflow }\end{array}$ & $\begin{array}{l}38.8 \\
26.1 \\
38.0 \\
56.1\end{array}$ & $\begin{array}{r}50.9 \\
122.4 \\
129.6 \\
150.1\end{array}$ & $\begin{array}{r}89.7 \\
148.5 \\
167.6 \\
206.2\end{array}$ & $\begin{array}{r}281 \\
2386 \\
995 \\
--\end{array}$ & $\begin{array}{r}15 \\
16 \\
4 \\
--\end{array}$ & $\begin{array}{r}1221 \\
2557 \\
1208 \\
--\end{array}$ & $\begin{array}{r}1517 \\
4959 \\
2207 \\
--\end{array}$ \\
\hline $3 / 26 / 70$ & $\begin{array}{c}C \\
D \\
E \\
\text { Outflow }\end{array}$ & $\begin{array}{l}23.7 \\
45.2 \\
59.3 \\
44.9\end{array}$ & $\begin{array}{r}82.0 \\
150.2 \\
115.9 \\
61.4\end{array}$ & $\begin{array}{l}105.7 \\
195.4 \\
175.2 \\
106.3\end{array}$ & $\begin{array}{r}1056 \\
1688 \\
1114 \\
88\end{array}$ & $\begin{array}{r}24 \\
30 \\
7 \\
6\end{array}$ & $\begin{array}{r}3007 \\
2838 \\
455 \\
20\end{array}$ & $\begin{array}{r}4087 \\
4556 \\
1576 \\
114\end{array}$ \\
\hline $4 / 3 / 70$ & $\begin{array}{c}C \\
D \\
A \\
\text { Outflow }\end{array}$ & $\begin{array}{l}22.0 \\
23.5 \\
78.2 \\
40.3\end{array}$ & $\begin{array}{l}36.7 \\
74.4 \\
74.8 \\
60.1\end{array}$ & $\begin{array}{r}58.7 \\
97.9 \\
153.0 \\
100.4\end{array}$ & $\begin{array}{r}1349 \\
397 \\
1268 \\
19\end{array}$ & $\begin{array}{r}32 \\
9 \\
11 \\
3\end{array}$ & $\begin{array}{r}267 \\
2566 \\
312 \\
2621\end{array}$ & $\begin{array}{l}1648 \\
2972 \\
1591 \\
2643\end{array}$ \\
\hline $4 / 9 / 70$ & $\begin{array}{c}\text { C } \\
D \\
\text { A } \\
\text { Outflow }\end{array}$ & $\begin{array}{l}49.1 \\
26.9 \\
52.7 \\
62.7\end{array}$ & $\begin{array}{r}102.6 \\
56.1 \\
116.7 \\
102.9\end{array}$ & $\begin{array}{r}151.7 \\
83.0 \\
169.4 \\
165.6\end{array}$ & $\begin{array}{r}1264 \\
906 \\
1335 \\
15\end{array}$ & $\begin{array}{r}40 \\
8 \\
22 \\
2\end{array}$ & $\begin{array}{r}2779 \\
2581 \\
282 \\
20\end{array}$ & $\begin{array}{r}4083 \\
3495 \\
1639 \\
37\end{array}$ \\
\hline
\end{tabular}


Figure 12. Wintergreen Lake showing locations of visible nutrient sources, associated lagoon complex and sampling stations during March and April 1970 . 


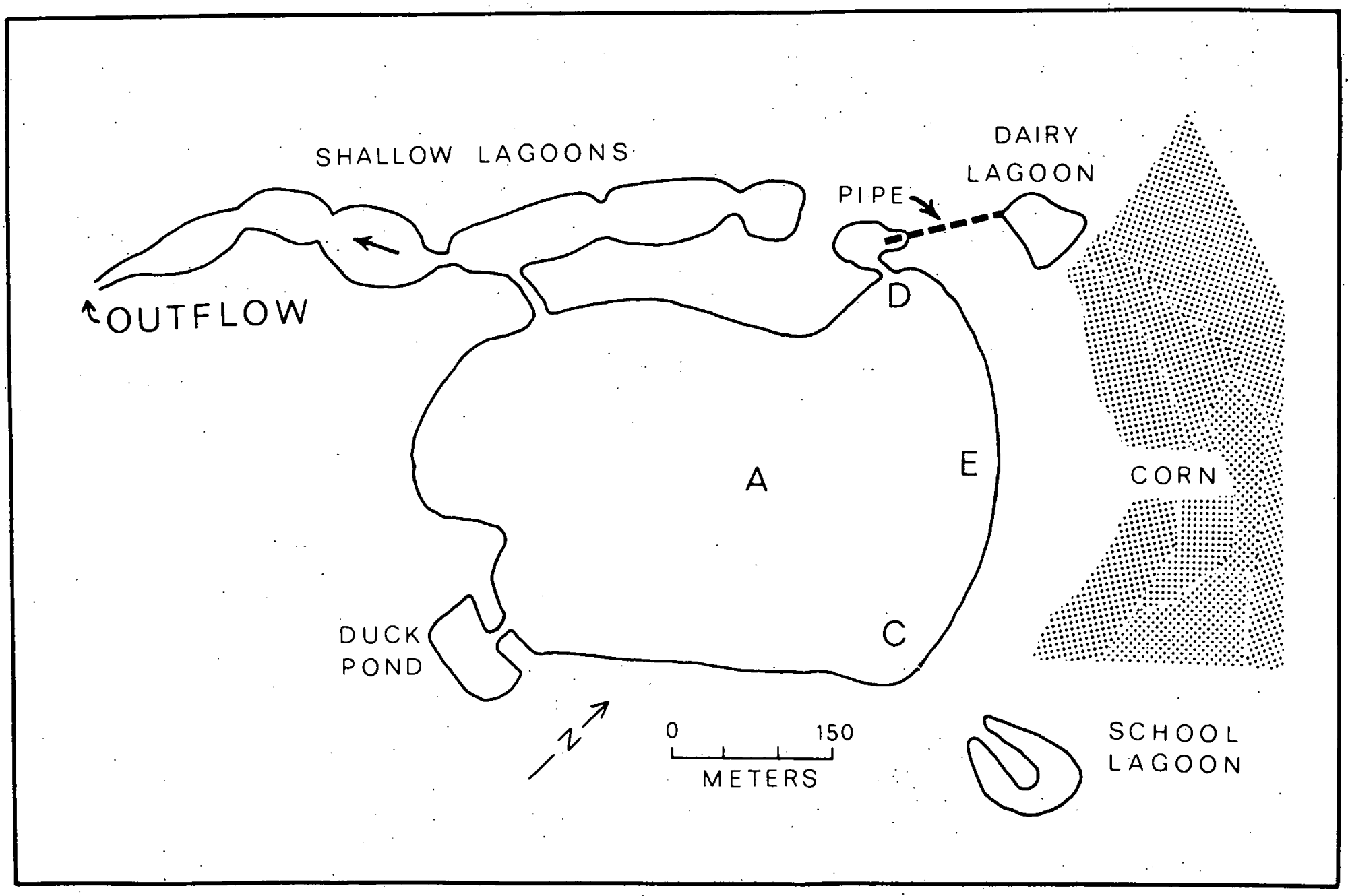


however, the latter may be significant during the spring when urea, liquid ammonia and granular nitrate fertilizer are applied during planting of corn. No attempt was made to quantify this source because movement of these ions would have been largely underground (Olsen et al., 1968). Vegetation in the lake and shallow lagoons was much more effective in removing nitrogen, particularly nitrate, than in removing phosphorus from water passing through the system (Table 3 ). On all dates, Stations $C$ and $D$ were 2-4 times higher in $\mathrm{NH}_{4}$ and total inorganic-N than Station A or the outflow. On all dates except 9 April, Station D was highest in total inorganic-N. Dissolved phosphorus comprised 22-50\% of total-P on all dates at all stations (Table 3 ). Water at Station A was usually higher than the other stations in both dissolved and total P. The most striking feature of the survey is the apparent failure of vegetation in Wintergreen to remove dissolved or total $P$ from water moving through the system at this time of year. Seldom was water at the outflow significantly lower in dissolved or total $P$ than the other three stations. The survey revealed uniformly high nitrate, nitrite, ammonia and phosphorus at all stations on all dates. Only nitrate was reduced significantly during passage through the lake and lagoon system of Wintergreen Lake in the spring. 


\section{PARTICULATE ORGANIC NITROGEN}

INTERACTIONS

In the following discussion, it will be important to understand changes that occurred within the phytoplankton present in Lawrence and Wintergreen lakes. Brief consideration is therefore given those aspects germane to organic nitrogen transformations.

\section{A. Lawrence and Wintergreen Lakes Phytoplankton}

Identification was normally carried only to genus because primary objectives in their treatment were: assignment of each organism to one of the three phyla common in algal blooms in temperate lakes, and (2) accuracy in determining cell surface area (SA) and volume (V) of individual colonies and cells. The latter objective was met by measuring essentially every alga counted, particularly those larger than 3 um maximum dimension; no published algal volumes were used. Both SA and V were calculated because Mullin, Sloan and Eppley (1966) and Strathmann. (1967) have found carbon and chlorophyll content is related more closely to cell surface area or cell plasma volume than to cell volume. Observation of 
these precautions assured surface area and volume determinations were accurate for later use in testing whether cellular organic nitrogen content of phytoplankton may be calculated from their carotenoid to chlorophyll a ratio on a surface area or volume basis (Manny, 1969).

Mucilaginous colonies presented a problem. Percent cell volume within the mucilage of each colony counted was estimated visually (range: 0.5 to $100 \%$ ). Surface area was later calculated using colony dimensions. By employing the percentage factor, only cellular volume was calculated within each colony. Estimates of Cyanophyta colonial surface area and cellular volume are realistic but estimates of Cyanophyta surface area/volume ratios are overestimates.

The terms net and nanno were assigned to those organisms of maximum dimension greater or less than $10 \mu \mathrm{m}$ assuming the latter would pass through $10 \mu \mathrm{m}$ Nitex netting. In actual practice, organisms larger than $10 \mu \mathrm{m}$ sometimes passed the $10 \mu \mathrm{m}$ Nitex but this discrepancy was counterbalanced during periods of high nannoplankton densities when organisms less than $10 \mu \mathrm{m}$ tended to accumulate on the $10 \mu \mathrm{m}$ Nitex. My nannoseston and nannophytoplankton categories are synonymous with the categories "nanoplankton" (Yentsch and Ryther, 1958), "nannoplankton" (Rodhe, Vollenweider and Nauwerck, 1958; Willen, 1961), "ultraplankton" (Wetzel, 1964), "ultraseston" and 
"nannoseston" (Hutchinson, 1967), overlapping in size only with the latter three categories.

Calculations based upon counts of samples from only I m depth in both lakes were made from July 1969 to March 1971. Results for 1970-71 (Table 4, Figure 13) showed any of the three phyla could have been interpreted as dominant at some point during the year, if only numbers, surface area or volume were calculated. Comparison of all three indices over the 13 months illustrated numerically dominant organisms such as the net Chlorophyta in February 1970 comprised only a small fraction of the total net volume during that period, an observation made previously in English waters by Moss (1969). Absolute net and nanno cell volumes in $\left(\mu \mathrm{m}^{3} / 1\right)$ for most of 1970 appear in Figures 14 and 18 .

In both lakes, nannophytoplankton comprised less than $25 \%$ of total algal cell volume most of the year except brief periods in December 1969 in Lawrence and February to April 1970 in both lakes. Except March and April 1970, nanno algal cell volume in Wintergreen was generally about 10 times greater than total algal cell volume in Lawrence Lake.

Percentage composition of each phyla within net and nanno categories showed nanno numbers, SA and $V$ in Lawrence were predominantly Chlorophyta. Net numbers, $\mathrm{SA}$ and $\mathrm{V}$ were usually about 2 parts Cyanophyta: 1 part 
Table 4. Dominant algal genera at $1 \mathrm{~m}$ depth in Lawrence and Wintergreen lakes during $1970-71$.

Month Lawrence Lake

January 1970

February

March

April

May

June

July

August

September

October

November

December

January 1971
Chlamydomonas, Microcystis, Alpanocapsa, Gomphosphaeria, Dinobryon

Chlamydononas, Microcystis, Aphanothece, Coelosphaerium, Cryptomonas

Chlamydomonas, Aphanothece, Synedra, Microcystis, Botryococcus, Aphanocapsa

Chlamydomonas, Synedra, Fragilaria, Synechococcus, Peridinium, Microcystis

Chlamydomonas, Synedra, Gomphosphaeria, Cyclotella, Peridinium

Chlamydomonas, Gomphosphaeria, Fragilaria, Cyclotella, Microcystis

Chlamydomonas, Gomphosphaeria, Fragilaria, Microcystis, Chroococcus, Cyclotella

Chlamydomonas, Microcystis, Aphanocapsa, Gomphosphaeria, Aphanothece Chlamydomonas, Microcystis, Aphanocapsa, Cyclotella, Gomphosphaeria Chlamydomonas, Microcystis, Aphanothece, Fragilaria, Gomphosphaeria Chlamydomonas, Microcystis, Fragilaria, Gomphosphaeria, Aphanothece Chlamydomonas, Microcystis, Cyclotella, Synedra, Fragilaria, Gloeocapsa

Chlamydomonas, Fragilaria, Cyclotella, Microcystis 


\begin{tabular}{|c|c|}
\hline Month & Wintergreen Lake \\
\hline January 1970 & Chlamydomonas, Euglena, Asterionella, Fragilaria, Cryptomonas \\
\hline February & $\begin{array}{l}\text { Chlamydomonas, Cryptomonas, Asterionella, Peridinium, Euglena, } \\
\text { Oscillatoria }\end{array}$ \\
\hline March & $\begin{array}{l}\text { Chlamydomonas, Euglena, Cryptomonas, Asterionella, Geminella, } \\
\text { Cyclotella }\end{array}$ \\
\hline April & $\begin{array}{l}\text { Chlamydomonas; Cyclotella, Aphanocapsa, Cryptomonas, Asterionella, } \\
\text { Synedra }\end{array}$ \\
\hline May & Chlamydomonas, Cryptomonas, Aphanizomenon, Anabaena, Microcystis \\
\hline June & $\begin{array}{l}\text { Aphanizomenon, Anabaena, Microcystis, Chlamydomonas, Aphanocapsa, } \\
\text { Ceratium }\end{array}$ \\
\hline July & Aphanizomenon, Aphanocapsa, Microcystis, Aphanothece, Chlamydomonas \\
\hline August & $\begin{array}{l}\text { Microcystis, Aphanizomenon, Aphanocapsa, Aphanothece, Ceratium, } \\
\text { Chlamydomonas }\end{array}$ \\
\hline September & $\begin{array}{l}\text { Aphanizomenon, Aphanocapsa, Chlamydomonas, Microcystis, Oscillatoria, } \\
\text { Oocystis }\end{array}$ \\
\hline October & $\begin{array}{l}\text { Aphanizomenon, Anabaena, Aphanocapsa, Microcystis, Chlamydomonas, } \\
\text { Ceratium }\end{array}$ \\
\hline November & Chlamydomonas, Aphanizomenon, Aphanocapsa, Asterionella, Fragilaria \\
\hline December & Chlamydomonas, Asterionella, Quadrigula, Scenedesmus \\
\hline January 1971 & Chlamydomonas, Microcystis, Asterionella, Ankistrodesmus \\
\hline
\end{tabular}


Figure 13. Relative percentage abundance of net and nannophytoplankton of the three major phyla by numbers, surface area and volume per liter at $1 \mathrm{~m}$ depth in Lawrence and Wintergreen lakes during 1970 . 


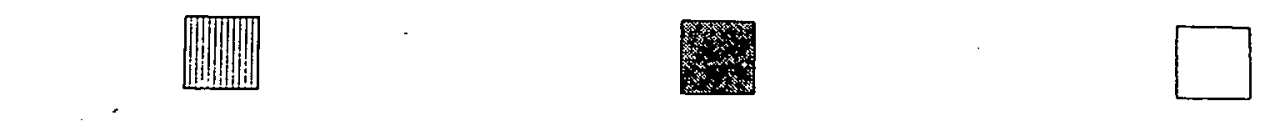

\section{CHLOROPHYTA CYANOPHYTA CHRYSOPHYTA}

\section{LAWRENCE}

WINTERGREEN

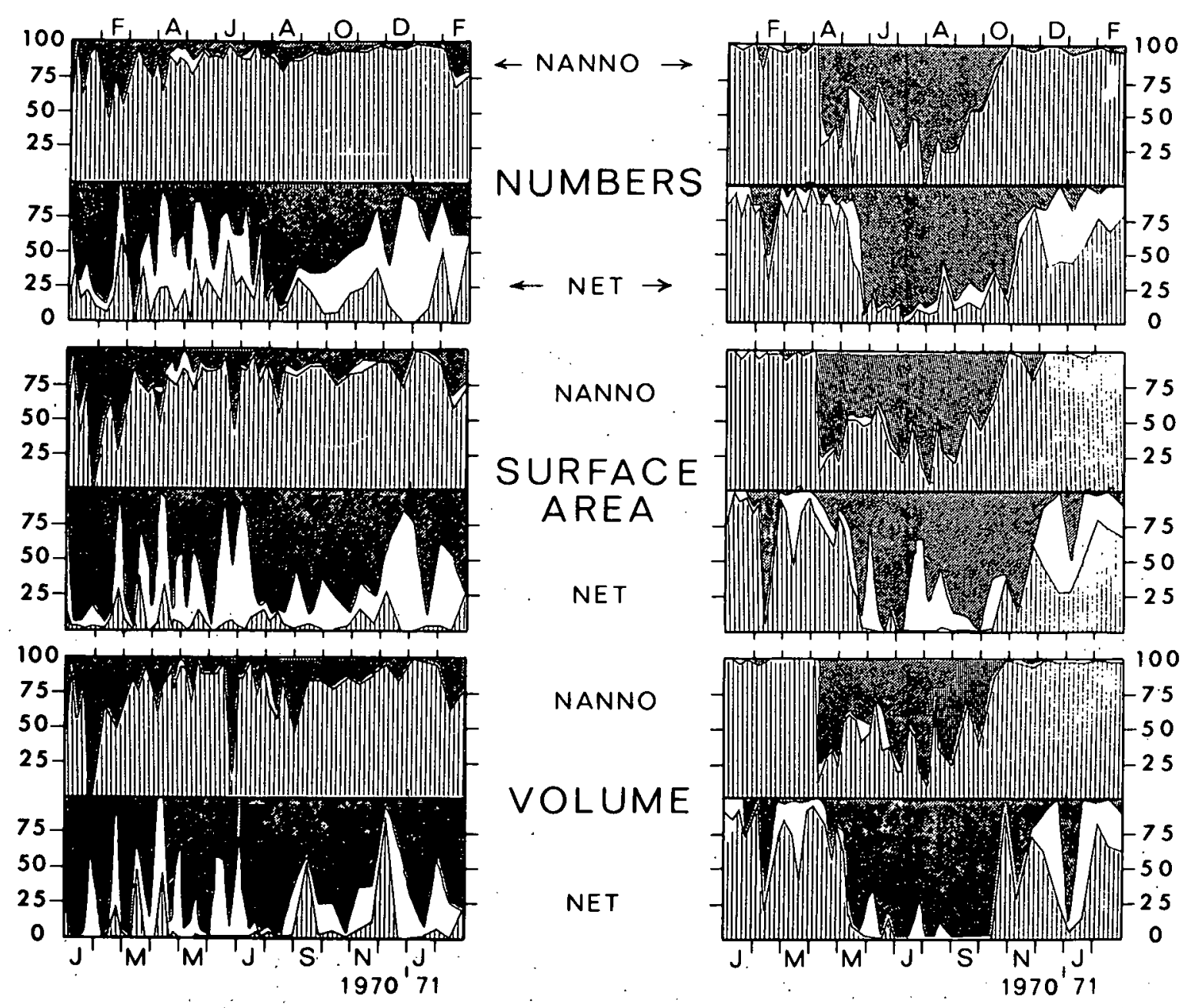


Chlorophyta:l part Chrysopyta. Net volume in Lawrence was dominated by the Cyanophyta for most of 1970-71. This latter result differs markedly from observations made by Dr. H. L. Allen throughout 1967-68; Cyanophyta were totally absent in Lawrence at $1 \mathrm{~m}$ depth except during August and September (R. G. Wetzel, personal communication). Numbers, SA and V corresponded more closely within net and nanno categories in Wintergreen than in Lawrence. Seasonal succession was also more evident in Wintergreen; populations changed from early dominance by small Chlorophyta to summer dominance by Cyanophyta and returned to mixed Chlorophyta and Chrysophyta dominance after fall overturn and under the ice. During the summer of 1969, few Cyanophytes were found in Wintergreen surface waters (G. S. Saunders, personal communication). Nanno Chlorophyta responsible for the spring bloom in Wintergreen during February and March 1970 were a mixture of six Chlamydomonas species. Extension of this initial bloom through April and May 1970 was effected by the development of many $\operatorname{small}(4 \times 8 \mu \mathrm{m})$ semi-elliptical Cryptomonad forms. Because these latter algae were included among the Cyanophyta, rapid increases in nanno Cyanophyta numbers, SA and $V$ appear in Figure 13 in early April, 1970. 


\section{B. Lawrence Lake Particulate Nitrogen}

More than $50 \%$ of total sestonic-N was present in the nannoseston fraction on 26 of 45 sampling dates during 1970 (Figure 14). At no time did nannosestonic-N comprise less than $25 \%$ of total sestonic-N. Maximum sestonic-N values during 1969-1970 occurred in September and November 1969 (112 and $97 \mu \mathrm{g} / 1$ respectively) and in March and April 1970 (108 and $95 \mu \mathrm{g} / 1$ respectively). These maxima corresponded more closely with changes in total algal cell volume than with changes in nanno algal cell volume. Minimum nanno and total sestonic-N values appeared during January 1970 .

In Lawrence Lake, total algal cell volume was nearly always 10 times greater than nanno algal cell volume. The latter comprised more than $25 \%$ of the total on only 11 of 58 sampling dates, namely in December 1969 and February to May 1970. This result differed markedly from the sestonic-N results. Whereas nanno algal cell volume rarely comprised more than $25 \%$ of total cell volume, nannosestonic-N always comprised more than $25 \%$ of total sestonic-N. Several explanations are possible. Arbitrary division of phytoplankton during microscopic examination may have excluded a significant portion of cells larger than $10 \mu \mathrm{m}$ that passed the $10 \mu \mathrm{m}$ Nitex on most sampling dates during the year. In retrospect, it would be very difficult to quantify to what extent 
Figure 14. Total sestonic nitrogen, nannosestonic nitrogen and percentage nannosestonic nitrogen with total algal cell volume, nanno algal cell volume and percentage nanno cell volume at $1 \mathrm{~m}$ depth in Lawrence Lake from July 1969 to October 1970 . 

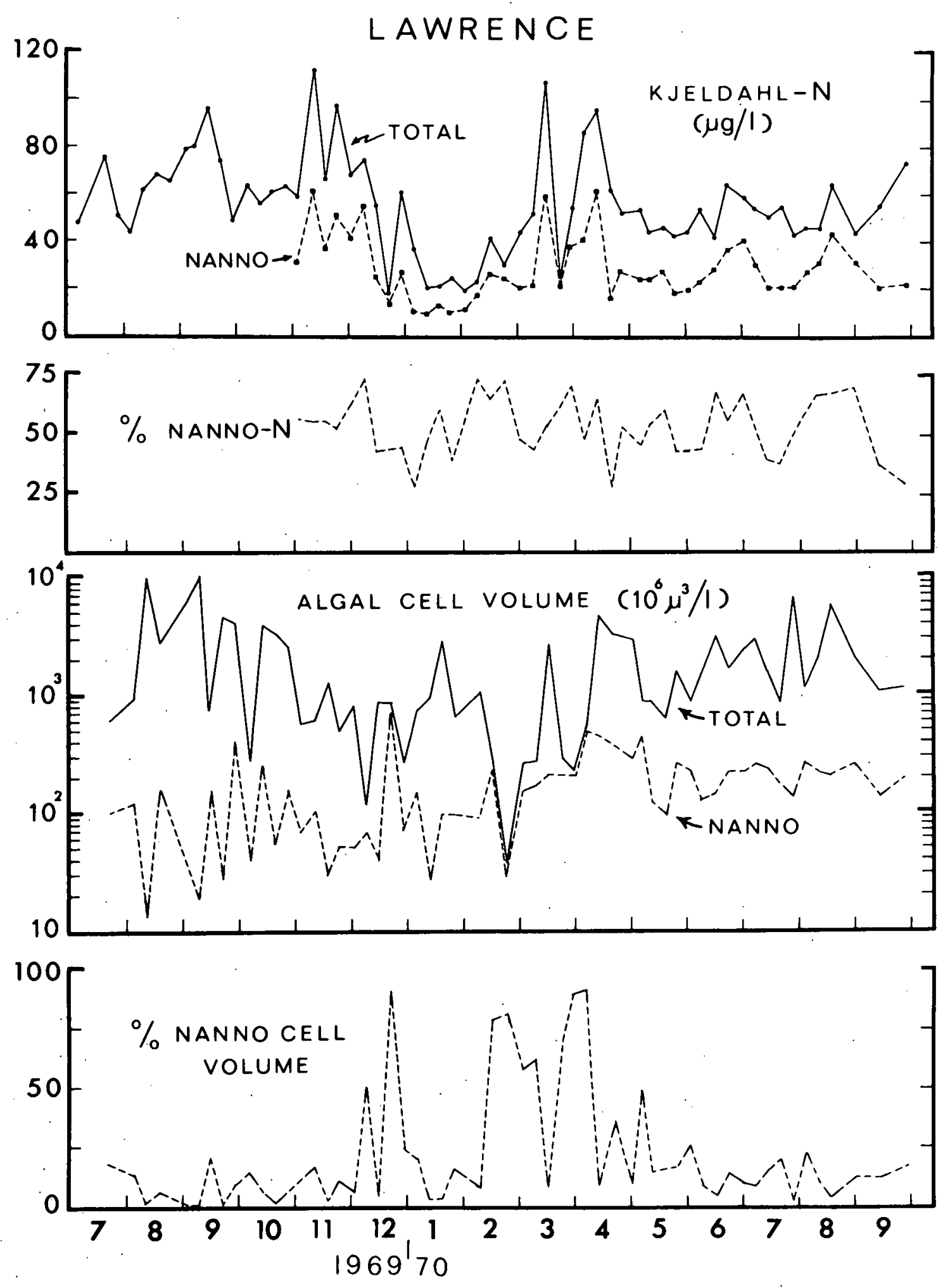
this set of data is confounded by the passage of netphytoplankton. Further problems are presented in that nets retain particles smaller than their stated porosity at the same time they pass larger particles (Sheldon and Sutcliffe, 1969). Seasonal changes in the various phytoplankters present in the two categories also enter into the problem. During some periods, an assortment of larger forms were present which could pass the net. In other periods, only very large netphytoplankters were present which almost surely did not pass the net. This problem will not be resolved without a more thorough program of immediate microscopic examination of both fractions as separated daily by the $10 \mu \mathrm{m}$ Nitex.

Another explanation of the high nitrogen content of nannoseston may be that nonalgal, nitrogen-rich material that passes $10 \mu \mathrm{m}$ Nitex may be present in Lawrence and Wintergreen seston most of the year. Microscopic examination of many preserved whole water samples did not support this possibility. Nonalgal material was seldom present in high quantities in samples from either lake. On the other hand, occasional microscopic examinations of unpreserved whole water samples secured during algal blooms and overturn in Lawrence often revealed numerous aggregates of crystalline material which disappeared when Lugol's acid-iodine preservative was added. Individual crystals of this material varied from the limit of 
resolution to about $20 \mu \mathrm{m}$ maximum dimension. Subsequent $\mathrm{X}$-ray diffraction analyses by $\mathrm{W}$. S. White identified similar material as $\mathrm{CaCO}_{3}$. If DON rapidly adsorbs to such particles in situ as demonstrated with water from Lawrence Lake in the laboratory (Wetzel and Allen, 1971), coatings of nitrogen-rich material were likely present in Lawrence Lake during blooms and periods of overturn. Efforts were not made to test this possibility further because seasonal changes in particle abundance could not be evaluated in retrospect.

Lastly, nannophytoplankton may be nitrogen-rich relative to netphytoplankton. This possibility was tested by dividing net and nannosestonic-N values by net and nanno algal cell volume present on each sampling date. Results showed nannophytoplankton contained about 10 times more nitrogen than netphytoplankton per unit cell volume. On all dates except late February, March and April 1970, nannophytoplankton in Lawrence Lake contained more nitrogen per unit cell volume than netphytoplankton (Figure 15).

C. Wintergreen Lake Particulate Nitrogen

Nannosestonic chlorophyll a comprised more than $50 \%$ of total sestonic chlorophyll a on all sampling dates except five from July 1969 to May 1970 (Figure 16). From May to September 1970 , nanno chlorophyll a comprised less than 30\% of total sestonic chlorophyll a. In April 1970, 
Figure 15. Organic nitrogen content per unit algal cell volume in net and nanno size categories at $1 \mathrm{~m}$ depth in Lawrence Lake from November 1969 to September 1970 . 


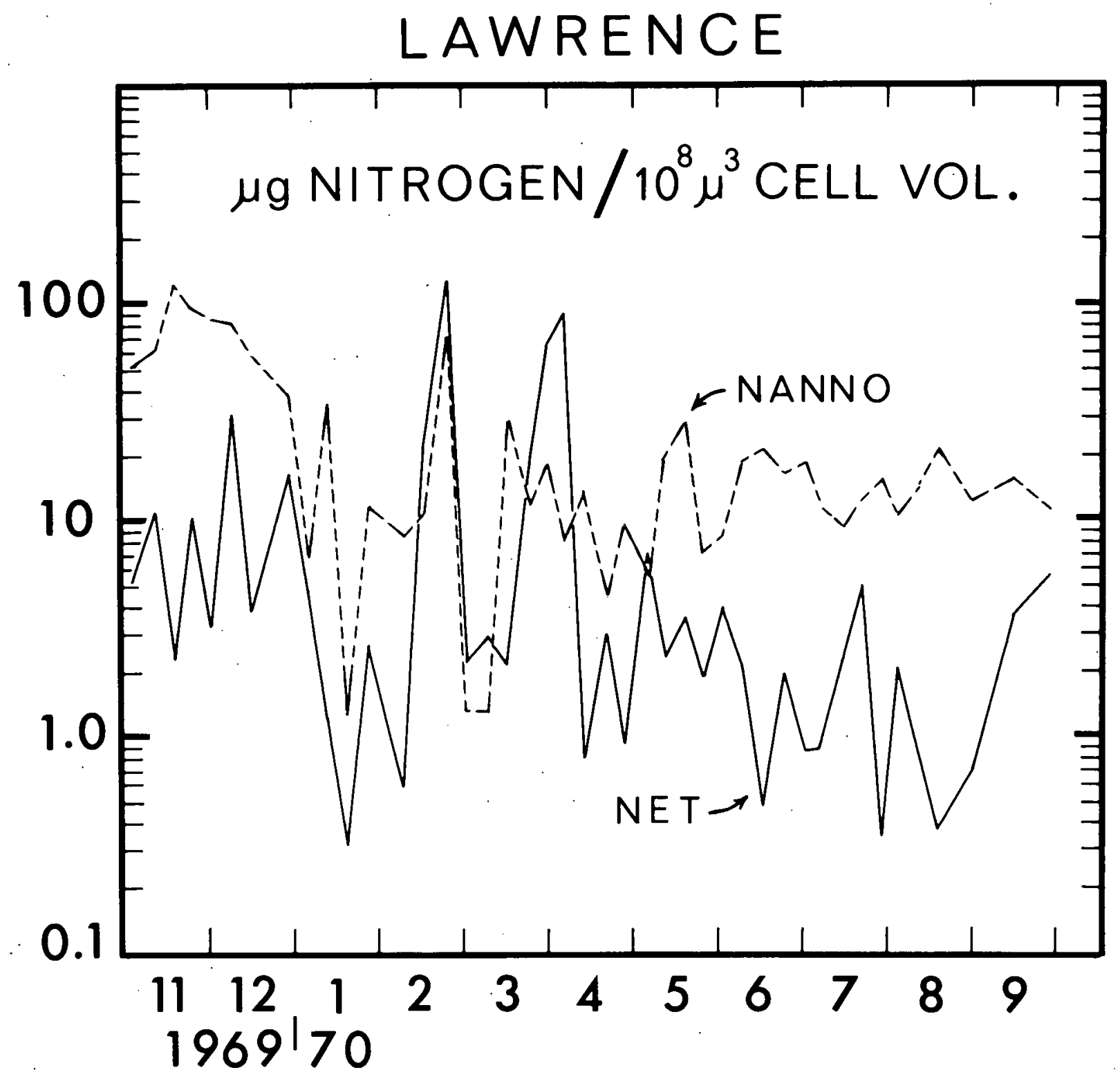


Figure 16. Corrected chlorophyll a in the total seston and nannoseston and percentage nanno chlorophyll a at $1 \mathrm{~m}$ depth in Wintergreen Lake from July 1969 to september 1970 . 
WINTERGREEN

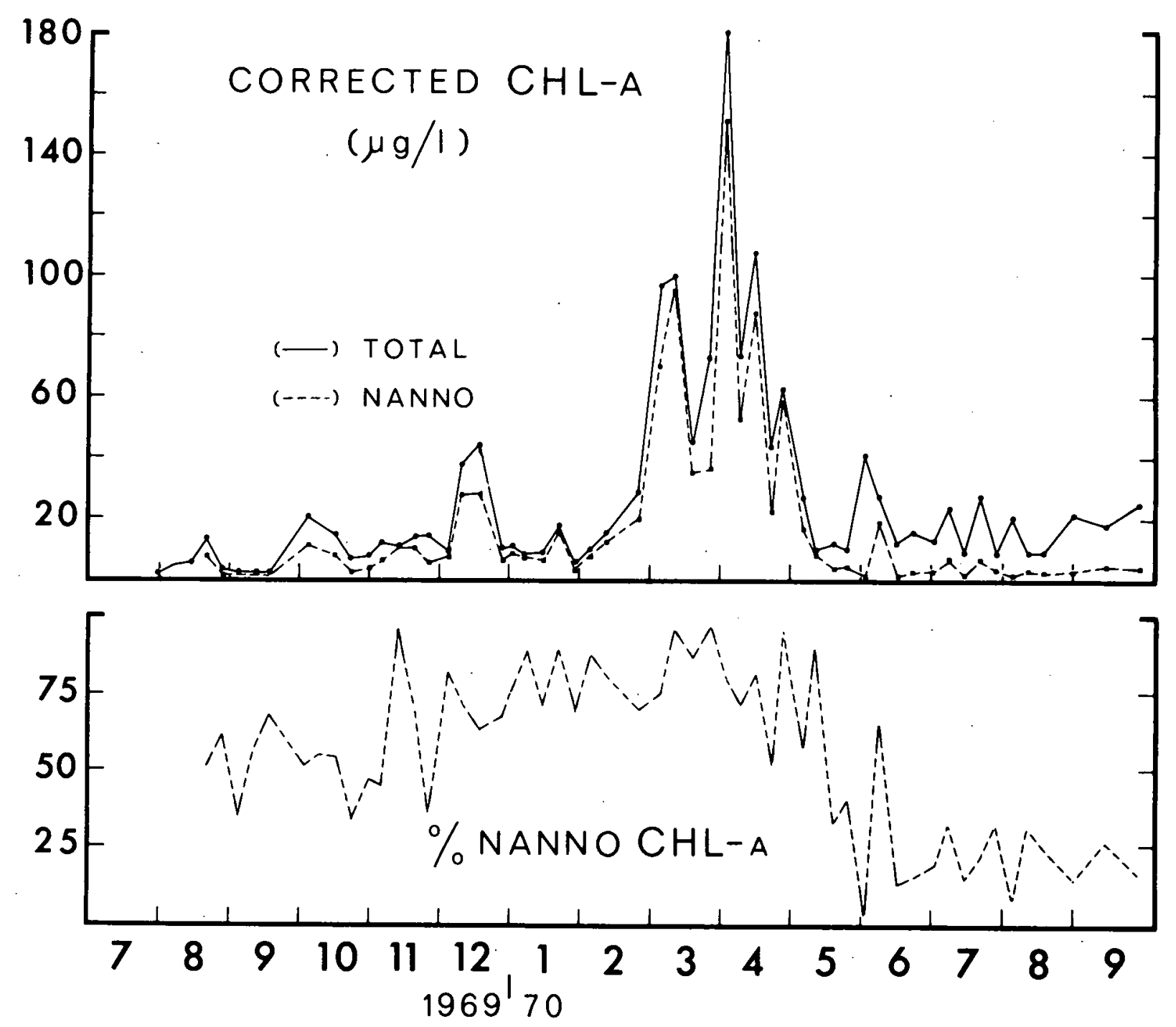


during the explosive development of a ChlamydomonasCryptomonas bloom, 80 to 978 of total sestonic chlorophyll a was present in the nannoplankton.

Total and nannosestonic-N followed much the same pattern as chlorophyll a (Figure 17). More than 50\% of total sestonic-N was present in material passing the 10 $\mu \mathrm{m}$ Nitex on 24 of 45 sampling dates. Maximum nannosestonic-N values, appeared during a Chlamydomonas bloom. in November and December 1969 and during the Chlamydomonas bloom in February and March 1970.

Relative nitrogen content in the net and nannophytoplankton size categories was also tested using data from Wintergreen Lake. Nanno algal cell volume usually comprised less than 10 of of total algal cell volume in Wintergreen (Figure 18) but nannosestonic-N comprised more than 50 of total sestonic-N most of the year (Figure 17). Nannophytoplankton was nitrogen-rich relative to the netphytoplankton per unit cell volume on 53 of 58 sampling dates (Figure 19).

Because nannophytoplankton are commonly held to be metabolically more active than netphytoplankton owing to higher $S A / V$ ratios, this ratio was calculated for net and nannophytoplankton in both lakes throughout 1970-71 (Figure 20). Nannophytoplankton ratios were less variable than netphytoplankton ratios in both lakes, but netphytoplankton frequently had ratios greater than nannophytoplankton present on the same date. 
79

Figure 17. Organic nitrogen content of the total seston and nannoseston and percentage nanno organic nitrogen at $1 \mathrm{~m}$ depth in Wintergreen Lake from July 1969 to september 1970 . 


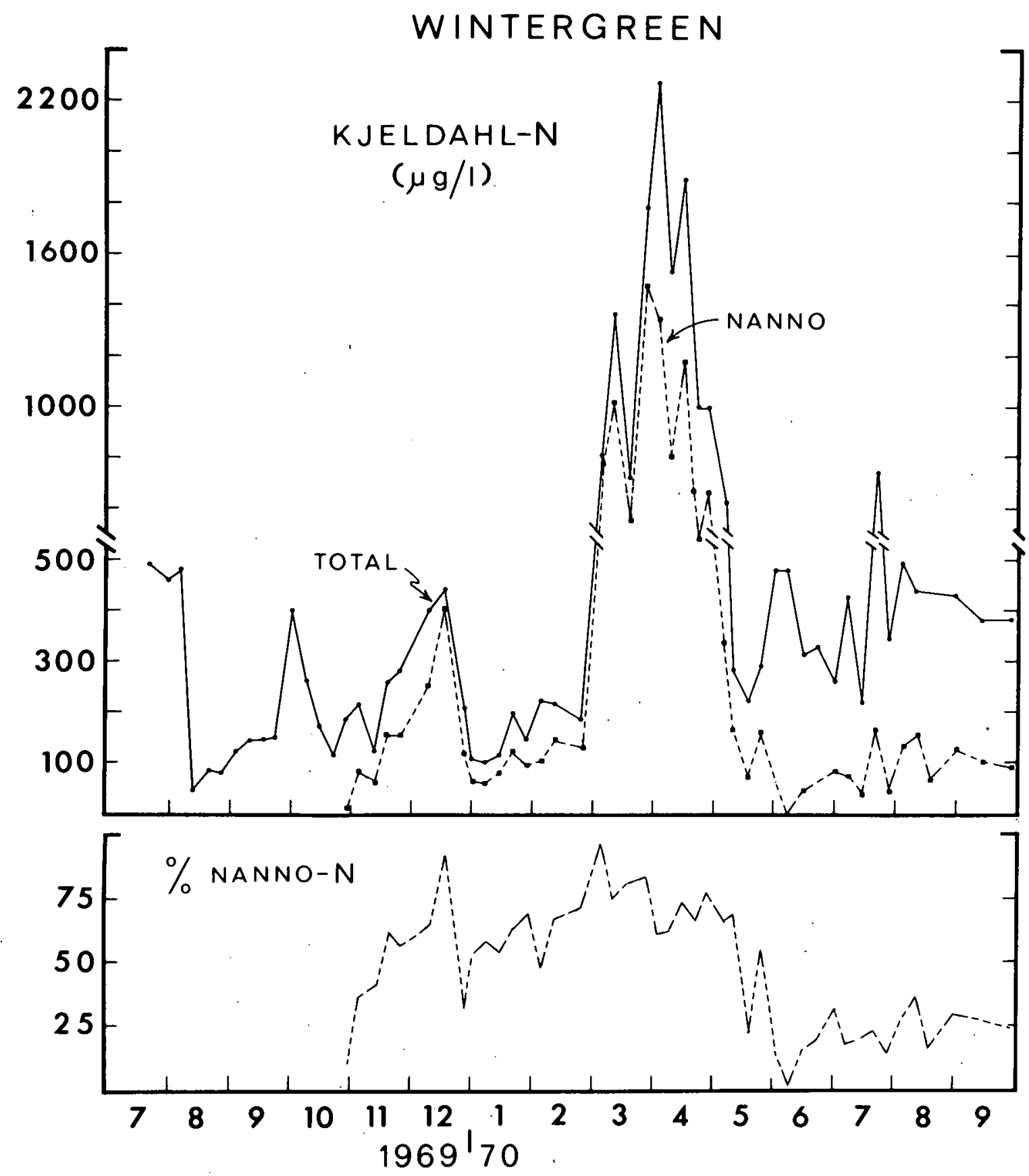


81

Figure 18. Total algal cell volume, nanno algal cell volume and percentage nanno algal cell volume per liter at $1 \mathrm{~m}$ depth in Wintergreen Lake from July 1969 to september 1970 . 

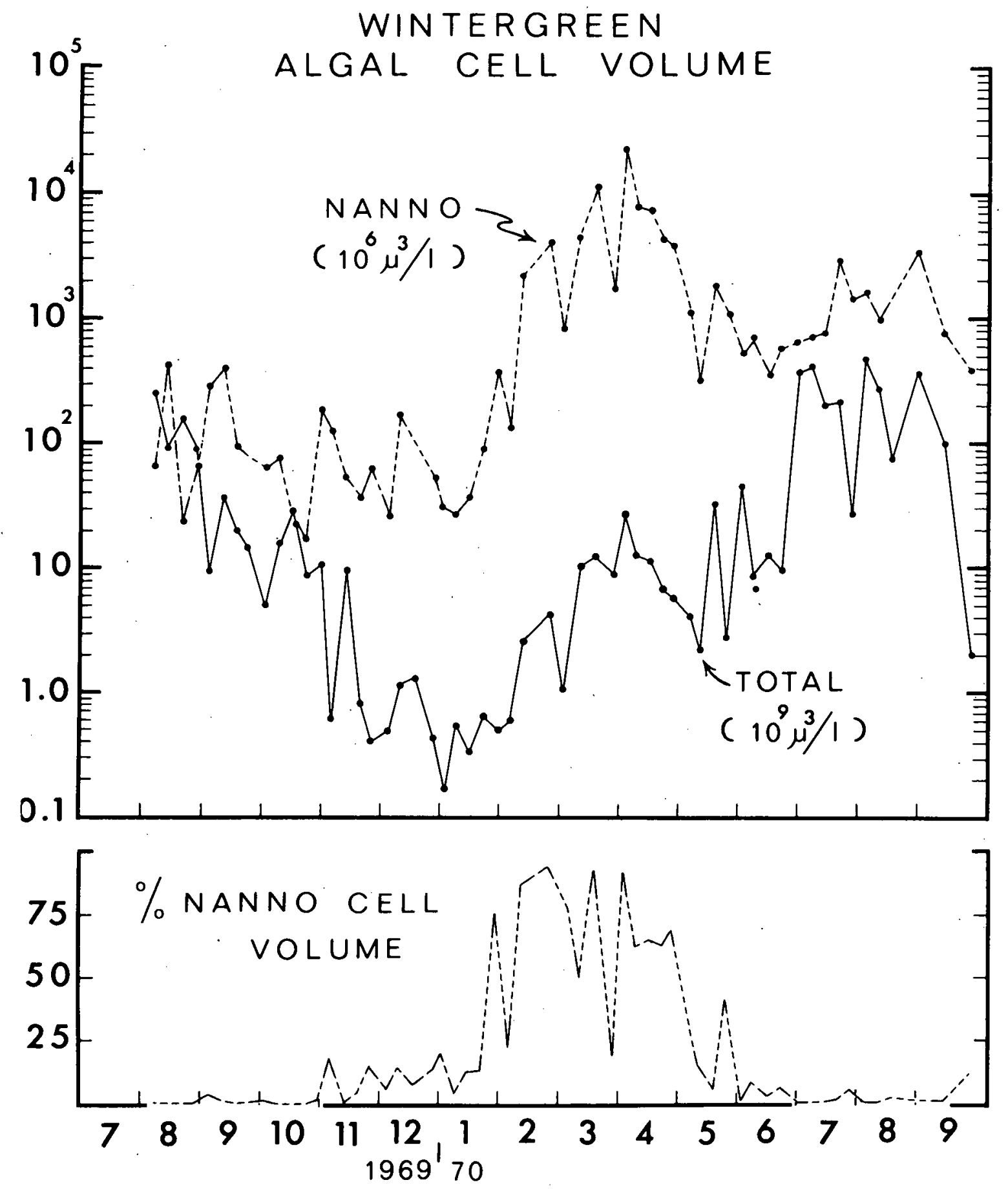
Figure 19. Organic nitrogen content per unit algal cell volume in the net and nanno size categories at $1 \mathrm{~m}$ depth in Wintergreen Lake from November 1969 to September 1970 . 


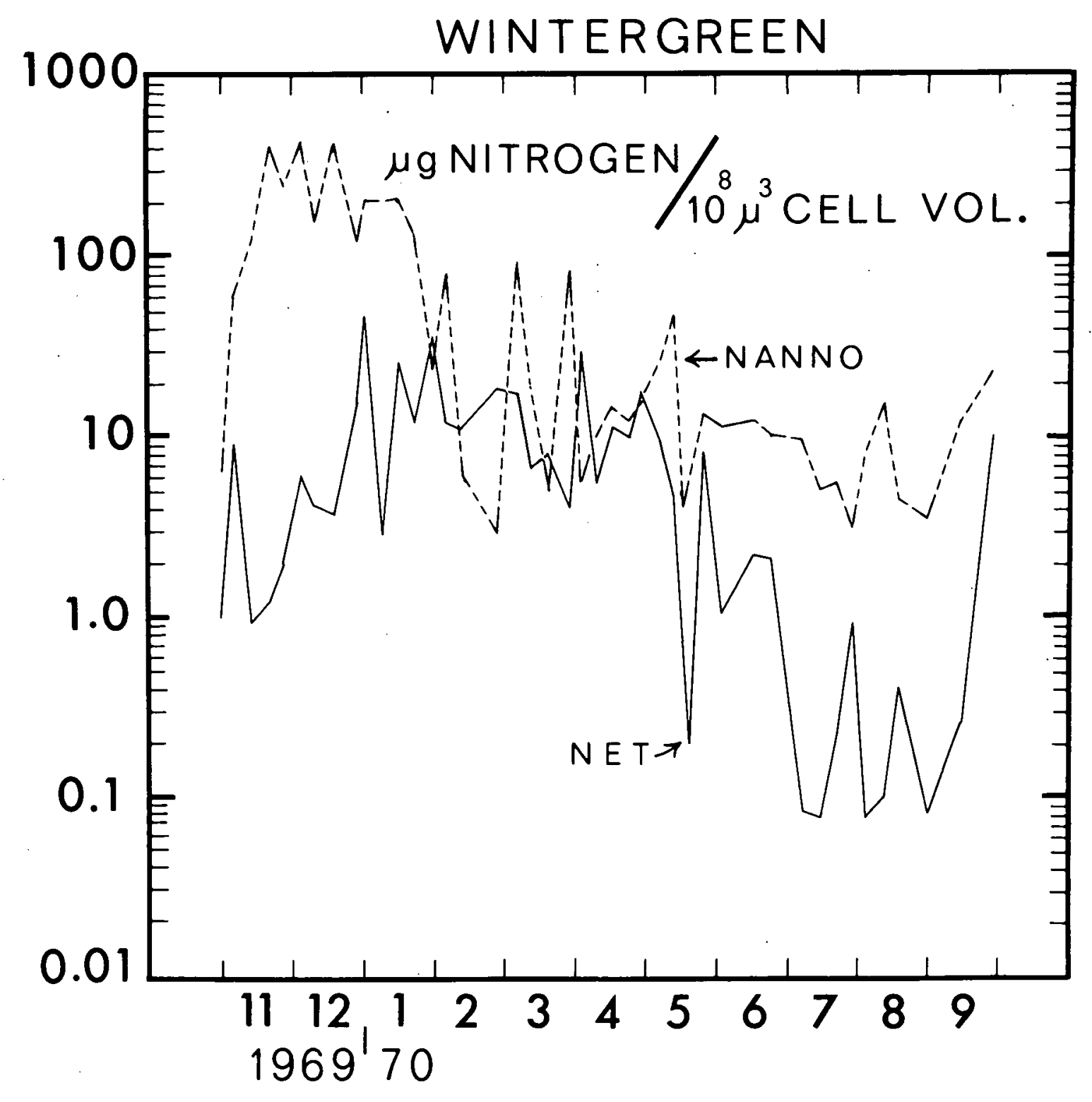


Figure 20. Algal surface area to volume ratios for net and nanno size categories in Lawrence and Wintergreen lakes at $1 \mathrm{~m}$ depth from February 1970 to February 1971. 

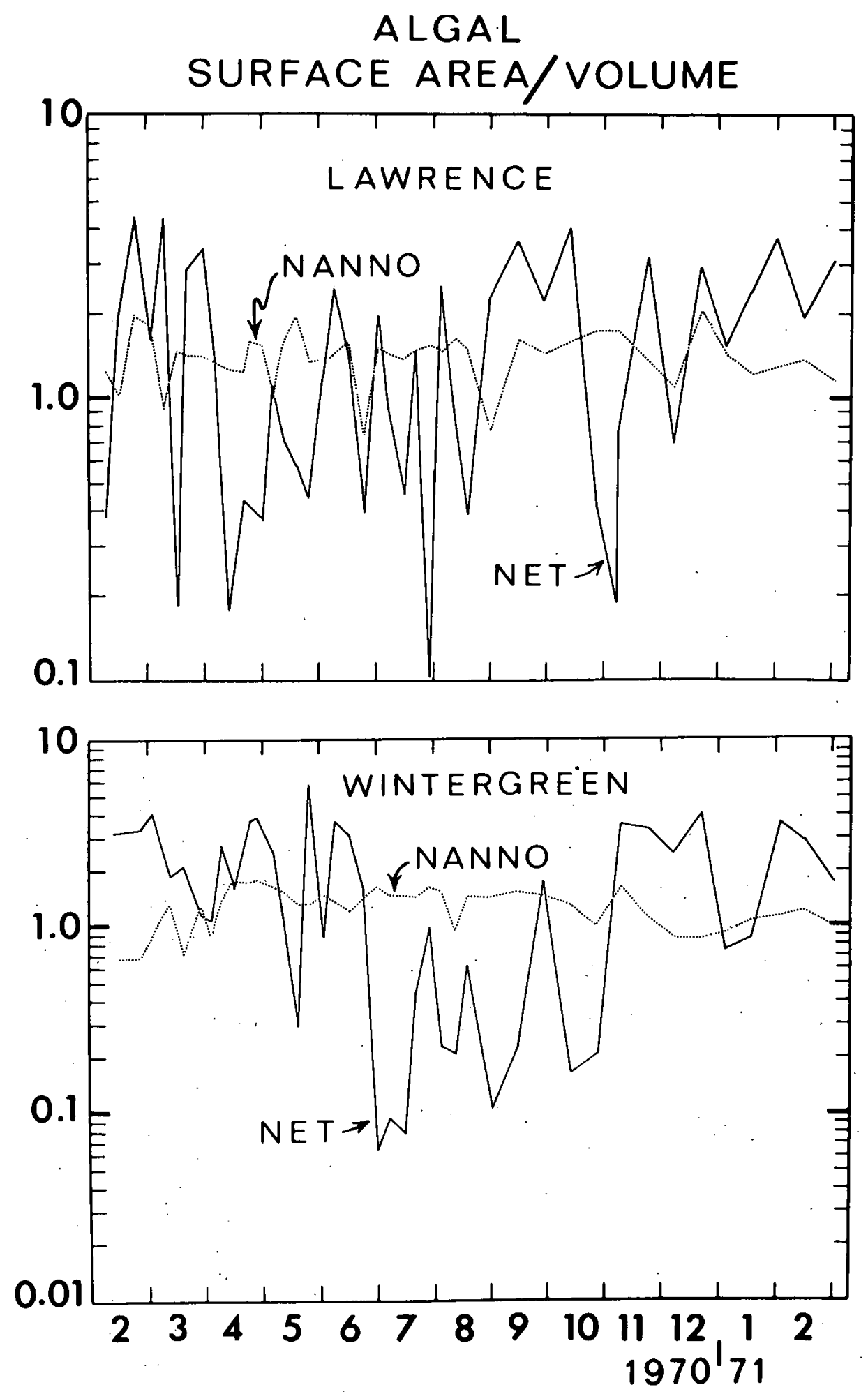
These data differ from the conventional approach of calculating $S A / V$ for individual cells in that they represent composite $\mathrm{SA}$ and $\mathrm{V}$ within the net and nanno size categories, which are the summation of many. individual $\mathrm{SA}$ and $\mathrm{V}$ values. After summing $\mathrm{SA}$ and $\mathrm{V}$ for all individual cells and colonies in the net and nanno categories in a given sample, net and nanno SA were divided by net and nanno $\mathrm{V}$ respectively. Inherent in the ratios of netphytoplankton are overestimates of colonial SA/V, when colonies were present, such as during August and september in both lakes. The best demonstration of net phytoplankton ratios greater than those of the nannophytoplankton was provided by the Asterionella bloom in November and December 1970 in Wintergreen. During this period Asterionella was dominant, yet net $S A / V$ remained above that of the nannophytoplankton between values of 2 to 5 .

One might conclude from these data that the conventional argument likely holds when applied individually to small phytoplankters, but it may not hold when applied to populations of larger colonial phytoplankters such as Asterionella that have adapted successfully to the planktonic existence by increasing their SA/V ratio. Additional tests of this hypothesis using various colonial and spined netphytoplankters such as Schroederia, Fragilaria, and Synedra and a scanning-electron microscope to estimate true surface areas would be quite interesting. 


\section{DISSOLVED ORGANIC NITROGEN INTERACTIONS}

\section{A. Introduction}

Dissolved organic nitrogen (DON) was found in lake water at concentrations six times greater than particulate organic nitrogen over 48 years ago (Birge and Juday, 1922). Since 1922, understanding of particulate organic nitrogen in lake metabolism has advanced while understanding of DON has not because DON rarely exceeds $0.5 \mathrm{mg} / 1$ and can not be concentrated conveniently. Recent studies of the nitrogen cycle give only passing mention to DON transformations (Kusnezow, 1959; Neese et al., 1962; Dugdale and Dugdale, 1965; Billaud, 1968; Barica, 1970). High intensity ultraviolet combustion of lake waters has recently been used to obtain 100-fold increased sensitivity over the micro-kjeldahl procedure (Manny, Miller and Wetzel, 1971). This technique measures DON at natural concentrations and permits characterization of UV-labile and UV-refractory DON fractions in a variety of lake types.

Mechanisms controlling cycling rates of dissolved organic compounds are intimately related to the regulation 
of lake metabolism and rates of eutrophication (Wetzel, 1965, 1966, 1967, 1969, 1970; Wetzel and Allen, 1971). Because DON is rapidly cycled between producer and decomposer organisms and because DON is likely responsible for complexing with many essential trace metals and plant nutrients, studies of DON function and interaction should provide fundamental insight into the regulation of biogeochemical cycles, photosynthesis and energy flow in lake metabolism.

Seasonal measurements of UV-labile (LDON) and UVrefractory dissolved organic nitrogen (RDON) in six Michigan lakes are compared below to illustrate relationships between DON and lake productivity. Results are summarized in a diagram of pelagic DON interactions believed to regulate aquatic photosynthesis in hardwater lakes (cf. Figure 32 , below).

1. Previous DON Analytical

Techniques

Attempts to characterize DON in fresh and brackish water have employed evaporation followed by microKjeldahl digestion (Domogalla, Juday and Peterson, 1925 ; Domogalla and Fred, 1926; Birge and Juday, 1934; Rainwater and Thatcher, 1960; Robertson and Powers, 1968); phosphotungstic acid precipitation (Domogalla et al., 1925); sodium decomposition (Shapiro, 1957); evaporation, gelfiltration (Sephadex), ion exchange or dialysis followed 
by colormetric or chromatographic amino acid analysis (Peterson, Fred and Domogalla, 1925; Schürmann, 1964; Brehm, 1967; Sieburth and Jensen, 1968; Litchfield and Prescott, 1970; Gocke, 1970; Wetzel, unpublished); kinetic bioassay of added amino acids (Hobbie, Crawford, and Webb, 1968; Hobbie and Crawford, 1969); and ${ }^{15} \mathrm{~N}$ labeling (Jones and Stewart, 1969a, 1969b).

Each of these techniques has certain shortcomings. Evaporation, ion-exchange and chromatography are timeconsuming and only semi-quantitative. Measurement with $1{ }^{\mathrm{N}}$ still involves a concentration step, is somewhat cumbersome and is expensive. Amino acid analysis, although subject to some of the above problems, is most useful because ${ }^{14} \mathrm{C}$-labeled compounds may be employed and specificity gained.

In the above studies, almost no attention was given to peptide and colloidal DON, which usually comprise $80 \%$ or more of the DON in natural waters (Brehm, 1967; Gocke, 1970), and no specific attention was given to complexing capacity of DON. These limitations hindered dynamic analysis of DON pools in situ and produced descriptive studies. The more important questions of possible regulation of photosynthesis by DON and bacterial metabolism of all DON fractions have been ignored. Until the board outlines of functional DON interactions in lake metabolism are known, simple characterizations of DON 
fractions and correlations of "chemical biomass" with observed biological events will be only partly elucidating.

2. UV Combustion

Ultraviolet combustion was originally developed for organic nitrogen determinations in seawater (Armstrong, Williams and Strickland, 1966; Armstrong and Tibbitts, 1968; Strickland and Parsons, 1968; Esumi and Saijo, 1969). Although UV combustion lacked the specificity of component analysis, this was compensated for by increased sensitivity, eliminating the need for concentration, and complete onestep recovery of all organic nitrogen, whatever its chemical nature. For freshwater applications the procedure was modified to include ammonia analyses because combustions of DON in freshwater produced a mixture of $\mathrm{NO}_{3}$, $\mathrm{NO}_{2}$, and $\mathrm{NH}_{4}$ (Manny, Miller and Wetzel, 1970). Constant pH and oxygen tension were maintained during combustion to achieve uniform results. As modified, the technique offers 100fold increased sensitivity over micro-Kjeldahl determi-

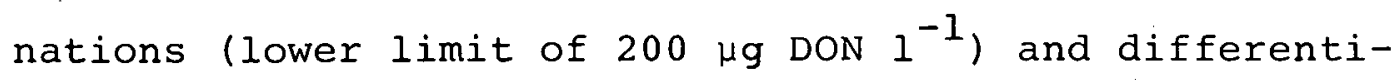
ation of labile and refractory DON fractions in lake waters on the basis of UV combustion rate and different combustion end products.

3. DON Production

Analysis of "functional," i.e., metabolic, organic constituents in natural waters increasingly appears 
to offer a new dimension in understanding dynamic aspects of lake metabolism (Hood, 1970). In lake metabolism, DON is involved in the processes of production (photosynthetic and allochthonous), utilization and transport-cycling (complexing, turnover time, etc.). Overall, it is important to realize that while dissolved organic substances enter lake water as transients, they exist therein as dynamic intermediates.

The few existing freshwater studies of in situ autotrophic dissolved organic matter production have dealt almost entirely with the release of organic carbon (Fogg, Nalewajko and Watt, 1965; Allen, 1969, 1971; Watt, 1966). Only watt (1966) documented in situ autotrophic DON production (alanine, serine, and glutamic acid) under natural conditions by assemblages of Nitzschia palea, Stephanodiscus hantzschii, Scenedesmus quadricauda and Ankistrodesmus falcatus. Other evidence of DON production has been obtained by culturing marine and freshwater algae. Filamentous blue-green algae, especially Anabaena cylindrica and members of the genus Calothrix, were among the first shown to release DON (Fogg, 1952, 1953; Watanabe, 1951; Whitton, 1965). Free amino acids (aspartic > glutamic > alanine) and a polypeptide capable of complexing $0.324 \mathrm{mg}$ copper per mg peptide-N, as well as $\mathrm{Fe}$ and $\mathrm{PO}_{4}$ ions, were released by Anabaena cylindrica (Fogg and Westlake, 1955). Another freshwater blue-green alga, Microcystis aeruginosa, 
releases a poisonous mixture of five polypeptides (Bishop, Anet and Gorham, 1959; Gorham, 1964). In addition, diatoms release glutamic acid, alanine, valine and serine (Watt, 1969) while members of the Chlorophyta release free amino acids (mostly aspartic and glutamic acids), peptide and Colloidal DON (Brehm, 1967; Gocke, 1970).

Among the marine algae, the Cyanophyta and Chlorophyta release free amino acids (largely alanine, serine and threonine) (Stewart, 1963; Hellebust, 1965) and peptide-N (Jones and Stewart, 1969b). DON released by Calothrix may comprise up to $64 \%$ of all nitrogen fixed.

In general, conditions influencing DON production by algae are light intensity, deficiencies of $\mathrm{K}, \mathrm{Fe}$ or Mo, age of the culture and previous nitrogen nutrition. Release can occur in the light and in the dark (Watt, 1969). Under an alternating 16:8 hr light-dark regime, axenic Scenedesmus quadricauda produced the three DON fractions in relative proportions of 1 free amino-N: 5 peptide-N: 4 colloidal-N. Conditions conducive to DON release and how the above parameters affect the relative proportions of the three fractions are presently unknown.

Although excretion of $\mathrm{NH}_{4}$, urea and amino acids is common among marine invertebrates including zooplankton (Nicol, 1967), DON release by freshwater zooplankton has apparently gone unrecorded. If freshwater zooplankton release DON, the pattern may resemble that of their marine 
counterparts. Dissolved nitrogen released by marine zooplankton is 60-100\% ammonia with some urea and lesser amounts of glycine, taurine and alanine comprising the remainder (Johannes and Webb, 1965; Corner and Newell, 1967; Jawed, 1969; Webb and Johannes, 1967, 1969; Butler, Corner and Marshall, 1970). The release was directly. proportional to temperature and sufficient to account for concentrations of these amino acids normally found in seawater.

Studies of DON originating from natural allochthonous and benthic sources are also rare. Brehm (1967) observed a marked increase in high-molecular weight peptides in surface waters of the Pluss-See following autumn leaf-fall, but the chemical nature of nitrogen in soils washing in with each rain is not yet fully known. Stevenson (1954) found 79-81\% of the total nitrogen in three soils was acid-soluble; $30 \%$ was alpha amino nitrogen. Nitrogen as free amino acids in soils is unlikely because soils contain a wide selection of metabolically active micro-organisms which utilize amino acids. This has been confirmed chemically (Sowden and Parker, 1953) and biologically (T. Gray, personal communication). Electrophoretic patterns of organic colloids extracted from clay soils did not disclose any free proteins. Other investigators have found amino acids are in or associated with the humic acid fraction extractable from soils (Breger, 
1963). Recent studies have disproved the common belief that nitrogen in humic acids was derived from undecomposed proteins (Manskaya and Drozdova, 1968). Nitrogen in humic acids is now believed to originate from plants and bacteria as amino acids which enter into the humic structure by a condensation reaction between the amino acids and aromatic carbohydrate portions of the molecule (the melanoidin reaction). This reaction has been studied extensively at normal to high temperatures with a variety of naturally occurring compounds such as chitin and glucosamine. Reaction products (melanoidins) have the same $C: N$ ratio $(10: 1)$ as humic acids.

Soluble humic substances of terrestrial origin contain an average of $3-5 \%$ organically bound nitrogen (Otsuki and Hanya, 1967; Kononova, 1961). Dark brown to cherry-red "newly formed" humic acids produced by cultures of molds, fungi and actinomycetes grown on glucose and mineral salts contained $2.8 \%$ nitrogen (Konova and Alexandrova, 1968) and upon hydrolysis yield the same amino acids obtained by hydrolysis of natural soil humic acids (Manskaya and Drozdova, 1968:57). Melanoidins produced by the reaction of glucoseamine and glycine contain 19.96\% N. During the reaction, fluorescent intermediates are formed which may be the source of fluorescent compounds that wash into Lawrence Lake after a rain (Miller, 1971). Plants of the littoral zone of lakes also play an important 
role of producing and processing DON entering the pelagic ecosystem (Wetzel and Manny, 1971).

Until recently, because of difficulties associated with culturing aquatic macrophytes, DON release by higher aquatic plants had not been observed. Axenic cultures of the littoral macrophyte, Najas flexilis have now been observed to release up to $100 \mu \mathrm{g}$ DON/dry g/da which is 98$100 \%$ UV-labile in completely defined inorganic media (Wetzel and Manny, 1971). DON release appears to be intimately linked to external physiological parameters such as temperature, $\mathrm{pH}$ and ionic concentration.

Only a few workers have studied the production of dissolved nitrogenous compounds during decomposition of particulate materials by natural bacterial flora. Of these, the work of Otsuki (1968) is most interesting because he characterized two butanol-extractable fractions (IR spectra) one of which is a mixture of proteins. which can be aggregated to support immature guppies (Poecilia reticulata) and Daphnia carinata for extended periods ( $A$. Otsuki, personal communication).

\section{DON Utilization}

DON production would have little impact on bacterial-autotrophic metabolism and pelagic productivity if it were not utilized by bacteria and autotrophs or did not affect the availability of nutrients needed for their growth. Studies have shown DON is utilized to some extent 
by many pelagic organisms but data for in situ DON utilization rates by pelagic organisms is almost completely lacking.

Vitamins, urea and amino acid utilization is well documented among terrestrial plants (McKee, 1962) and freshwater algae (Provasoli and Pinter, 1960; Provasoli, 1960; Danforth, 1962). Aspartic acid, succinamide and asparagine were among the compounds most rapidly utilized as the sole $\mathrm{N}$-source by fourteen species of Chlorophyta (Algeus, 1950a, 1950b). Scenedesmus and Chlorella have also been shown to utilize glycine (Algeus, 1948) urea and uric acid (Hutner and Provasoli, 1964; Hodson and Thompson, 1969). This ability of Scenedesmus and Chlorella to utilize a wider variety of organic substrates may partially explain their predominance in sewage lagoons (Allen, 1955). One Cyanophyte (Aphanizomenon gracile) has been shown to utilize amino acids from casein peptone (Brehm, 1967). Gocke (1970) showed a selective active uptake mechanism for asparagine and glutamine was present in Scenedesmus quadricauda in addition to a passive uptake mechanism for threonine, serine, glycine and alanine.

Work with marine phytoplankters has shown requirements for thiamine, biotin and vitamin $B_{12}$ by representatives of virtually all phyla (Droop, 1957). A wide variety of DON are as suitable as inorganic-N sources for growth of centric diatoms (Provasoli, 1960; Guillard, 1963), 
pennate diatoms (Lewin, 1963), and many chrysomonads (Pinter and Provasoli, 1963, 1968). Amino acid uptake rates from mixtures at natural concentrations are rapid but selective, governed by sustainable, non-inducible active transport mechanisms and related to rates of $\mathrm{CO}_{2}$ photoassimilation and concentrations of inorganic nitrogen sources (Provasoli and McLaughlin, 1963; Eppley and MaciasR, 1963; Hellebust and Guillard, 1967; Dooren de Jong, 1967; Kretovich, Evstigneeva and Tomova, 1970; North and Stephens, 1967, 1968). These latter authors present convincing data in support of the hypothesis that, under some conditions, algal uptake of organic solutes is proportional to reduced $\mathrm{N}$, not reduced $\mathrm{C}$, requirements. This hypothesis could explain the slow natural glucose and acetate uptake rates of some marine and freshwater algae attributed to diffusion (Wright and Hobbie, 1965, 1966; Hobbie and Wright, 1965), but would not explain the active carbon uptake by algae observed at substrate concentrations $>10 \mathrm{mg} \mathrm{I}^{-1}$ (Hobbie, personal communication). Most of the above studies present little evidence on direct algal utilization of higher molecular weight nitrogenous compounds (peptides, and colloidal-N) excreted by algae at concentrations higher than those of the free amino acids (Brehm, 1967; Gocke, 1970). Furthermore, virtually all uptake studies have been conducted in axenic culture at very high substrate concentrations. Results 
of these studies are, therefore, likely not representative of events in situ (Fogg, 1959, 1966).

Because of difficulties encountered in isolating root and stem systems and in obtaining axenic plants, data on DON utilization by aquatic macrophytes are few. Wetzel and McGregor (1968) demonstrated marked growth stimulation by Najas flexilis in cultures containing up to $15 \mathrm{\mu g}^{-1}$ vitamin $\mathrm{B}_{12}$ but no stimulation using thiamine or biotin. Similar negative results were obtained with Lemna minor using vitamin $B_{1}$ by Gorham (1941, in Sculthorpe, 1967). More recently, Najas flexilis in culture has been shown to assimilate three amino acids from nearly natural concentrations at rates approximating those of bacteria (Wetzel, in prep.).

Uptake of amino acids by zooplankton appears to be negligible (Johannes, Coward and Webb, 1969), however, indirect uptake via ingestion of DON absorbed on detritus and organic aggregates may be significant (Otsuki, Hanya and Yamagishi, 1969). Organic aggregates do occur naturally in seawater (Riley, 1963) but their formation by aerating algal culture filtrates is dependent on the presence of bacteria (Barber, 1966; Jones and Stewart, 1969b). When produced artificially by aeration of filtered seawater, organic aggregates supported Artemia salina twice as long as a starved cohort, but not for an entire life cycle (Baylor and Sutcliffe, 1963). 
Bacteria are important in ecosystems because of their role in biogeochemical cycles. The "principle of microbial infallability" states that bacteria can decompose almost any organic molecule, regardless of its complexity (Alexander, 1964). All nitrogenous molecules are not, of course, degraded at the same rate. Excepting some nucleic acids (Brock, 1970), large colloids and peptides are first reduced to simple peptides or amino acids by exopeptidases activated by $\mathrm{Mg}$, $\mathrm{Mn}$ or $\mathrm{Fe}$, before crossing the membrane (Doelle, 1969). Substrate uptake (utilization) then proceeds by active transport (Kay and Gronlund, 1969) depending on substrate lability, i.e., how little energy need be expended by the cell to transform it into a product suitable for necessary syntheses or metabolic function. Utilization of nitrogen sources would then proceed: colloids < peptides < amine > $\mathrm{NH}_{4}>$ $\mathrm{NO}_{3}$ (Doelle, 1969; Brock, 1970).

In lakes, most bacteria are found growing epiphytically, epibenthically and on suspended clay-particle surfaces (Brock, 1966). In contrast to a planktonic existence, this habit would encourage faster growth because dissolved organic compounds and $\mathrm{NH}_{4}$ adsorb to these surfaces but, at present, the relative importance of surface bacterial colonization in lake nitrogen metabolism is unknown. In the pelagic system DON utilization by bacteria may be significant owing to the very great 
surface area offered within any water volume by the many organic and inorganic micro-particles.

Bacterial nutrition has been studied conventionally after isolation on growth media to amplify otherwise unmeasurable responses (Botan, Miller and Kleerekoper, 1960). This approach is unsuitable for measuring natural in situ substrate utilization both technically and because existing isolation media are probably suitable for less than 108 of the bacteria effecting DON transformations in lakes (Stumm-Zollinger, 1968; M. Klug, personal communication). These conditions give added credence for the need of experimental approaches such as that of Hobbie, Crawford and Webb (1968), corrected for respiration (Hobbie and Crawford, 1969), in which natural uptake rates for simple amino acids were estimated in situ.

Although new techniques are being developed to better characterize in situ bacterial nutritional requirements (Fonden, 1969; Perfil'ev and Gabe, 1969; Caldwell and Hirsch, 1971), few attempts are being made to expand the in situ rate approach using other amino acids or more refractory peptide and colloidal DON.

\section{B. Methods}

Analytical precision and accuracy of the $\mathrm{NO}_{3}$ and $\mathrm{NO}_{2}$ technique in DON measurement are high; minimum detectable amounts in a $1 \mathrm{~cm}$ cell \pm two standard errors were $3-8 \pm 1.76 \mathrm{ug} \mathrm{I}^{-1}(\mathrm{~N}=6)$. Ammonia determinations 
(Solorzano, 1969) in calcareous lake water in a $1 \mathrm{~cm}$ cell were nearly as precise $\left(5-12 \pm 1.93 \mathrm{\mu g} \mathrm{l}^{-1}, \mathrm{~N}=6\right)$ but a standard amount of ammonia added to subsamples of combusted water was not consistently recovered owing to the method's sensitivity to changes in $\mathrm{pH}$ and reagent addition sequence (Harwood and Huyer, 1970a, 1970b) and possibly ammonia adsorption to suspended monocarbonate particles (Toetz, 1970). For this reason, internal standards of $100 \mathrm{\mu g} \mathrm{I}^{-1}$ $\mathrm{NH}_{4}$ were included with each sample sequence from each lake or stream to assess a factor by which ammonia values were corrected for incomplete recovery. Recovery of added ammonia in Lawrence Lake water varied from 30 to $100 \%$ (mean: $79.18, \mathrm{~N}=31$ ) and was consistently less than recovery in water from Wintergreen Lake (range: 40 to $100 \%$, mean: $83.9 \%, \mathrm{~N}=29$ ).

Because only one sample was routinely combusted from each lake on any date, it was not possible to estimate field sampling variance or the significance of changes in DON between dates. On one occasion (7 November 1970), duplicate water samples from $12 \mathrm{~m}$ in Lawrence were combusted giving RDON values of 148 and $242 \mu \mathrm{g} \mathrm{N} 1^{-1}$ and LDON values of 108 and $135 \mu \mathrm{g} \mathrm{N} 1^{-1}$. On two occasions, samples were collected within 2-3 days of each other at the same station and depth. Between 17 and 20 February 1970 at $1 \mathrm{~m}$ in Duck Lake, RDON changed from 252 to $155 \mathrm{\mu g}$ $\mathrm{N}^{-1}$ and LDON from 304 to $351 \mu \mathrm{g} \mathrm{I}^{-1}$. Between 7 and 9 
November 1970 at $1 \mathrm{~m}$ in Lawrence Lake, LDON changed from 168 to $151 \mathrm{\mu g} \mathrm{N} \mathrm{I}^{-1}$. Future measurements of DON will include replicate samples at several depths and stations on Lawrence and Wintergreen lakes to better estimate seasonal variations in DON statistically.

During 7.5 months storage of a filtered, acidified sample $(\mathrm{pH} 3.6)$ in the dark at $4^{\circ} \mathrm{C}$, no biological activity was evident visually. Following storage, 418 of the LDON detected initially in the sample was detected as RDON. Total DON remained unchanged.

Duplicate subsamples removed from the combustion unit at $0.0,0.25,0.5,1.0$ and 2.0 hr during each combustion permitted statistical comparison of critical differences between initial and final RDON and LDON values. Routine tests of significance were made $(p=0.05)$ between initial and final values using the least significant difference test (Steel and Torrie, 1960). RDON and LDON values given here are significantly different from zero unless otherwise noted.

\section{Results}

1. UV-labile and UV-refractory DON

Previous work showed DON release and the final product distribution of DON between $\mathrm{NO}_{3}, \mathrm{NO}_{2}$ and $\mathrm{NH}_{4}$ were a function of: (1) the molecular nature of the DON, (2) the concentration of total dissolved organic carbon 
(TDOC), and (3) the inorganic salt concentration (Manny et al., 1971). The basis for fractionation is that only half the UV light energy required to break $C=N$ bonds (93 $\mathrm{kcal} / \mathrm{mole})$ is required to break $\mathrm{C}-\mathrm{N}$ bonds $(48 \mathrm{kcal} /$ mole) (McLaren and Shugar, 1964). Under acidic, oxygenated conditions $\mathrm{C}-\mathrm{N}$ nitrogen appeared first in solution (15-30 min) as $\mathrm{NH}_{4}$ and was not oxidized. After $30 \mathrm{~min}$ irradiation, $C=N$ nitrogen appeared in solution as a mixture of $\mathrm{NO}_{2}+\mathrm{NO}_{3}$ reaching maximum concentrations within $2.0 \mathrm{hr}$. This differential rate of $\mathrm{NH}_{4}$ and $\mathrm{NO}_{3}+\mathrm{NO}_{2}$ release was closely related to but not synonymous with the number of single $\mathrm{C}-\mathrm{N}$ bonds and aromatic (ring) $\mathrm{C}=\mathrm{N}$ bonds in the DON (Manny et al., 1971). Hence, aromatic nitrogen atoms require longer UV exposure for recovery. Additions of amino acids, nitrite and glucose to mixtures of ammonia, nitrite and nitrate in distilled water and lake water prior to and during irradiation for $2 \mathrm{hr}$ revealed: (1) complete recovery of $\mathrm{C}-\mathrm{N}$ as $\mathrm{NH}_{4}$, (2) the ratio of $\mathrm{NO}_{3}: \mathrm{NO}_{3}+\mathrm{NO}_{2}$ was a constant (0.75) unless altered to another equilibrium value by other solutes in the lake water. This ratio could be altered from the final equilibrium value by adding nitrite but the 0.75 equilibrium quickly became reestablished, and (3) the rate of $\mathrm{U}^{14} \mathrm{C}$-glycine oxidation was retarded in proportion to the concentration of TDOC and inorganic salts in solution, including $\mathrm{NO}_{3}, \mathrm{NO}_{2}$ and $\mathrm{NH}_{4}$ (Manny et al.' 1971). 
Recovery of glycine- $\mathrm{N}$ added to distilled water solutions and water collected from Wintergreen Lake on 28 April 1970 was determined after $0.5 \mathrm{hr}$ irradiation. An inverse relationship was found between glycine-N recovery and increasing TDOC concentrations (Figure 21). Similar measurements were made weekly during combustions of water from Lawrence and Wintergreen lakes. Consistently, 60-90\% of final $(2.0 \mathrm{hr})$ LDON in both lakes was recovered after 0.5 to $1.0 \mathrm{hr}$ whereas less than $75 \%$ of final RDON appeared during the same period (Figure 22). DON in Lawrence was most labile (most readily decomposed) during late June, August through September and October but more refractory during mid-May and December through January when a progressive decrease in DON lability occurred. No consistent relationship emerged between changes in DON lability and percent reduction of nitrate to nitrite. This reduction was a feature of each combustion of water from Lawrence Lake (Figure 23). It is presently unclear why nitrate is reduced to nitrite during combustion of water from Lawrence Lake. Perhaps reduction is related to the high nitrate levels and nature of dissolved organic compounds in Lawrence. During the spring, nitrate reduction also occurred during combustions of water from Gull and Wintergreen lakes (Figure 24).

LDON levels in Wintergreen were always 5-10 times higher than those in Lawrence and LDON in Wintergreen was 
Figure 21. Percentage recovery of 400 or $600 \mu \mathrm{g} / 1$ glycine-N after $0.5 \mathrm{hr}$ combustion in distilled water solutions and water from Wintergreen Lake containing different amounts of dissolved organic carbon as glucose and potassium hydrogen pthalate. 


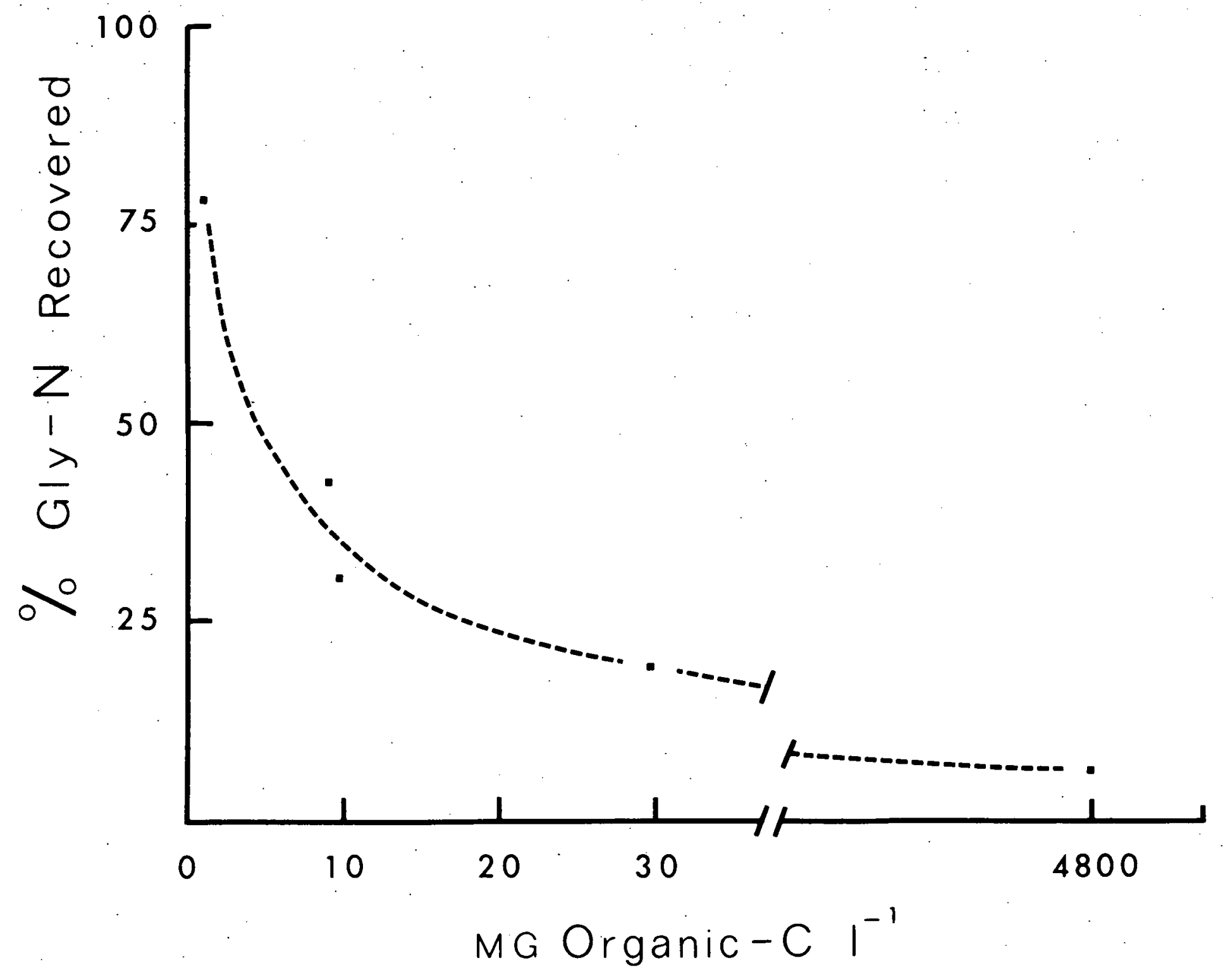


Figure 22. Percentage of final (2.0 hr) LDON and RDON release and percentage of final $\mathrm{NO}_{3}$ reduction at the indicated times during irradiation of water from $1 \mathrm{~m}$ depth in Lawrence and Wintergreen lakes from May 1970 to March 1971. 

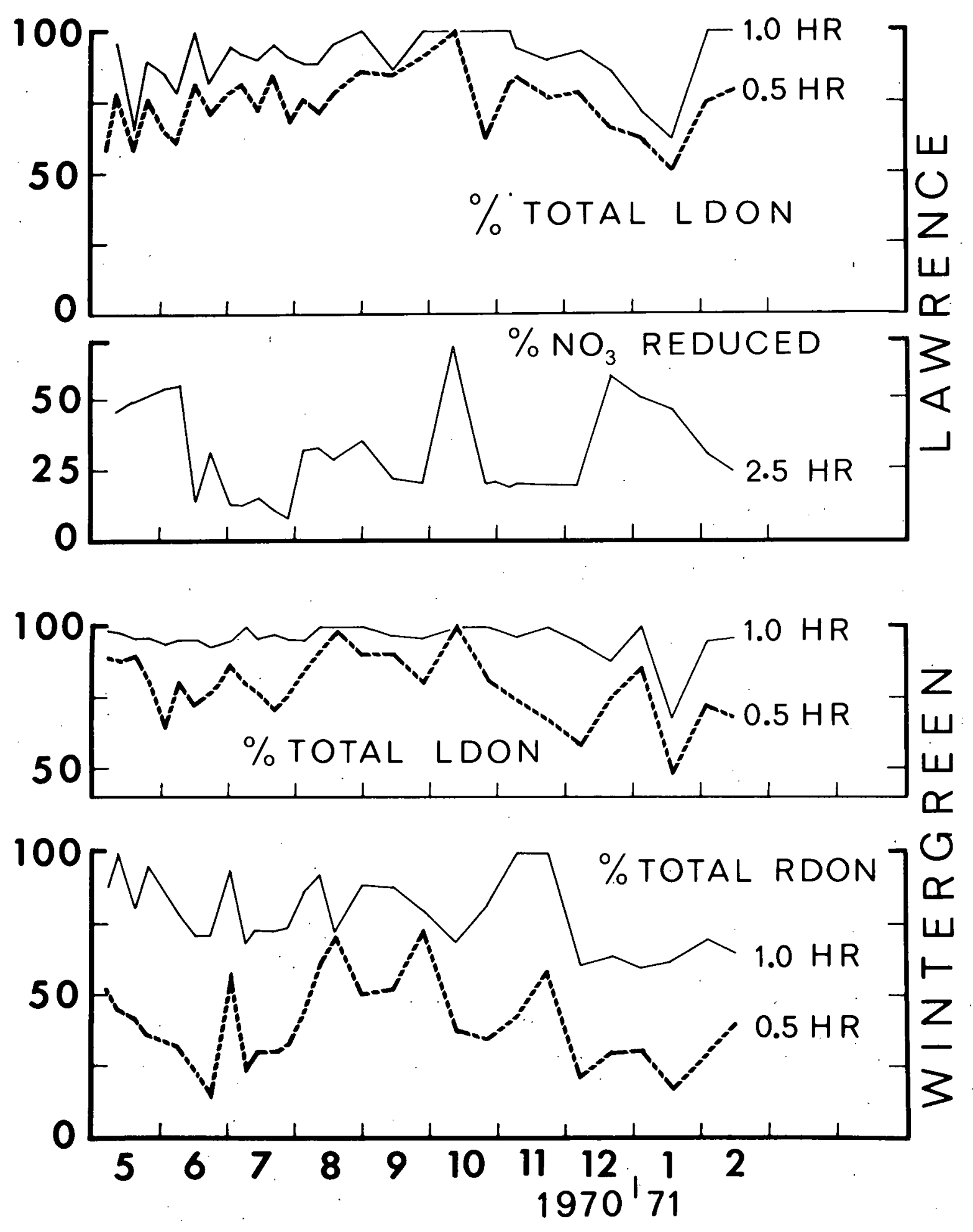
Figure 23. Net changes in $\mathrm{NO}_{3}+\mathrm{NO}_{2}$ (hatched bars) $\mathrm{NO}_{2}$ (left-middle bars), $\mathrm{NO}_{3}$ (right-middle bars), and $\mathrm{NH}_{4}$ (open bars) after $2 \mathrm{hr}$ UV-irradiation of water from Lawrence and Wintergreen lakes during the summer months 1970. Hatched bars equal RDON and open bars equal LDON for each date. 
TEMPORAL $\triangle N \quad 1970$

LAWRENCE \& WINTERGREEN LAKES

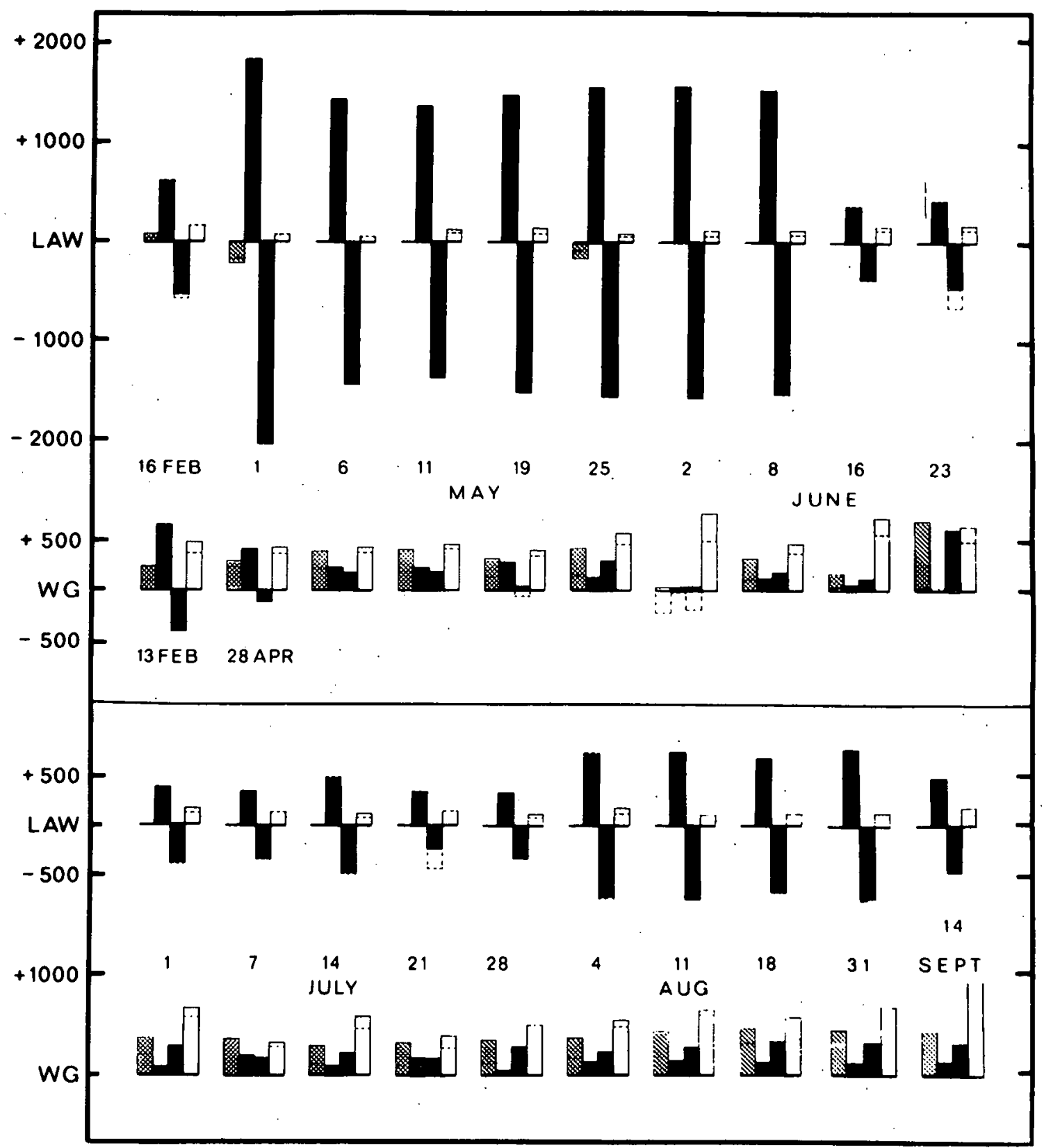


Figure 24. Seasonal net changes in (left to right)

$\mathrm{NO}_{3}+\mathrm{NO}_{2}$ (RDON), $\mathrm{NO}_{2}, \mathrm{NO}_{3}$ and $\mathrm{NH}_{4}$ (LDON) in six Michigan lakes during the month/year indicated. Shaded areas represent the net change, after $0.5 \mathrm{hr}$ irradiation, of each component. February 1970 combustions of Purdy, Duck, Cassidy, and Gull lakes were of $<1.0 \mathrm{hr}$ duration; other combustions were of $2.0 \mathrm{hr}$ duration. 

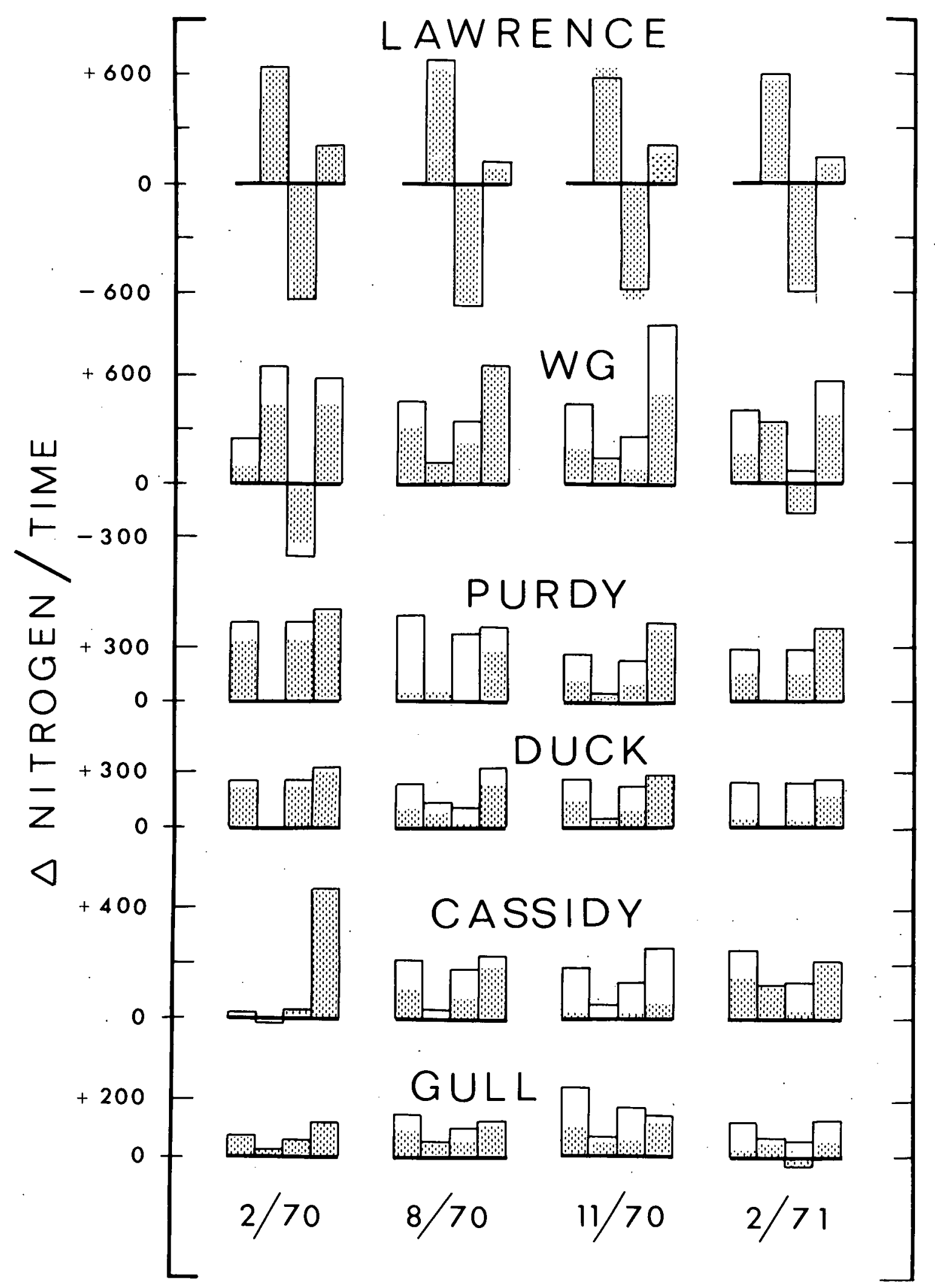
$2 / 71$ 
generally released more rapidly throughout the year than LDON in Lawrence (Figure 22). LDON in both lakes was most labile in October prior to turnover. Changes in RDON in Wintergreen resembled changes in LDON only during early July and mid-August.

2. Seasonal Changes in Six Michigan Lakes

Additional perspective was gained by measuring DON in four lakes representing advanced stages of trophic development or conditions of intermediate productivity between Lawrence and Wintergreen. Chemical data for the six lakes appeared in Manny et al. (1971). Lawrence is a deep $(12.6 \mathrm{~m})$, unproductive, marl lake (alkalinity 4-5 meq/l); Wintergreen is a shallow $(6.3 \mathrm{~m})$ hypereutrophic lake of lesser alkalinity $(2.8 \mathrm{meq} / \mathrm{l})$; Purdy is a shallow $(2.0 \mathrm{~m})$ highly stained, organic-rich Sphagnum bog of intermediate productivity; Duck is a shallow $(4.0 \mathrm{~m})$ dystrophic, soft-water lake; Cassidy is a deep (10.5 m) stained, alkaline lake of low productivity and Gull is a deep $(36.5 \mathrm{~m})$ oligotrophic, marl lake of higher productivity than Lawrence.

Initial analysis of data at $1 \mathrm{~m}$ depth established the following orders of LDON and RDON abundance:

Spring 1970 LDON: WG $>$ Purdy $>$ Cass $>$ Duck $>$ Law $>$ Gull RDON: Purdy > Duck > WG > Gull > Cass > Law 
Summer 1970 LDON: WG $>$ Purdy $>$ Duck $>$ Cass $>$ Gull $>$ Law RDON: Purdy $>$ WG $>$ Duck $>$ Cass $>$ Gull $>$ Law

Fall-Winter 19.70

LDON: WG > Purdy > Duck > Cass > Law > Gull RDON: WG $>$ Duck $>$ Purdy $>$ Gull $>$ Cass $>$ Law

Spring 1971 LDON: WG > Purdy > Duck > Cass > Law > Gull RDON : WG > Purdy > Cass > Duck > Gull > Law

In each lake, consistently higher concentrations of LDON and RDON appeared in the epilimnion than in the hypolimnion on a majority of sampling dates (Table 5). Expression of combustion results as net change in each product after 0.5 and $2.0 \mathrm{hr}$ irradiation revealed individual seasonal combustion patterns (Figure 24). Purdy and Duck were most alike throughout the year and were the only lakes in which nitrite failed to appear during combustion either spring. Lawrence had the most consistent pattern characterized by strong nitrate reduction, modest LDON content and complete lack of RDON. Cassidy lacked pattern but resembled Duck and Purdy in the proportions of LDON and RDON comprising TDON. Cassidy also failed to show nitrate reduction. Gull and Wintergreen showed modest nitrate reduction in the spring.

In general, seasonal changes in DON did occur in the six lakes but patterns for each lake were essentially individual. Detailed comparison of DON changes in Lawrence 
Table 5. UV-labile (LDON), UV-refractory (RDON) and total (TDON) dissolved organic nitrogen concentrations $(\mu \mathrm{g} / \mathrm{l})$ in five Michigan lakes illustrating higher concentrations of LDON, RDON and TDON near the surface.

\begin{tabular}{|c|c|c|c|c|c|c|c|}
\hline \multirow{2}{*}{ Lake } & \multirow{2}{*}{ Depth (m) } & \multicolumn{3}{|c|}{ November 1970} & \multicolumn{3}{|c|}{ February 1971} \\
\hline & & LDON & RDON & TDON & LDON & RDON & TDON \\
\hline \multirow[t]{2}{*}{ Lawrence } & 1.0 & 218 & $<1$ & 218 & 148 & $<1$ & 148 \\
\hline & 5.0 & 176 & $<1$ & 176 & 146 & $<1$ & 146 \\
\hline \multirow[t]{2}{*}{ Wintergreen } & 1.0 & 877 & 440 & 1317 & 564 & 407 & 971 \\
\hline & 3.0 & 657 & 328 & 985 & 647 & 206 & 853 \\
\hline \multirow[t]{2}{*}{ Duck } & 1.0 & 308 & 265 & 573 & 262 & 245 & 507 \\
\hline & 3.0 & 277 & 257 & 534 & 351 & 204 & 555 \\
\hline \multirow[t]{2}{*}{ Cassidy } & 1.0 & 261 & 183 & 444 & 210 & 254 & 464 \\
\hline & 10.0 & 417 & 139 & 556 & 177 & 179 & 356 \\
\hline \multirow[t]{2}{*}{ Gull } & 1.0 & 151 & 252 & 403 & 136 & 122 & 258 \\
\hline & 14.0 & 110 & 171 & 281 & 90 & 122 & 212 \\
\hline
\end{tabular}




\section{7}

(Figure 25) and Wintergreen (Figure 26) revealed only one simultaneous increase during August and September 1970. Attempts were made to find relationships between changes in DON and other related parameters. First TDOC and TDON were compared because Birge and Juday (1934) found the ratio of $\mathrm{C} / \mathrm{N}$ was nearly constant in 157 seepage lakes and 51 drainage lakes. In Lawrence, a significant correlation was present between changes in TDOC and TDON $(p>0.01$ ) from February to July 1970 (Figure 27) but no correlation was present during the entire year (Figure 28). Changes in LDON were negatively correlated with average changes in TDOC and rates of primary production in the 0-2 m stratum throughout 1970-71 (Figure 25). During August and September 1970 (square points, Figure 28), a period of maximum Cyanophyta densities, the organic matter at $1 \mathrm{~m}$ in Lawrence was comparatively $\mathrm{C}-\mathrm{rich}$ and $\mathrm{N}$-poor. Later, during a period of high chlaymdomonad densities (February 1971, square point, Figure 28) the organic matter was comparatively N-rich.

No correlation was found between changes in DON in Lawrence and changes in phytoplankton volume (Figure 29). Cyanophyta cellular volume was not included in Figure 29 because it bore no discernible relationship to DON. Several DON maxima coincided with Chlorophyta or Chyrsophyta maximum cell volumes. If DON is related to changes in phytoplankton densities, the relationship may 
Figure 25. Comparison of annual changes in LDON, average TDOC and rates of ${ }^{14} \mathrm{C}$ primary productivity in the 0-2 $\mathrm{m}$ stratum of Lawrence Lake from May 1970 to March 1971. 


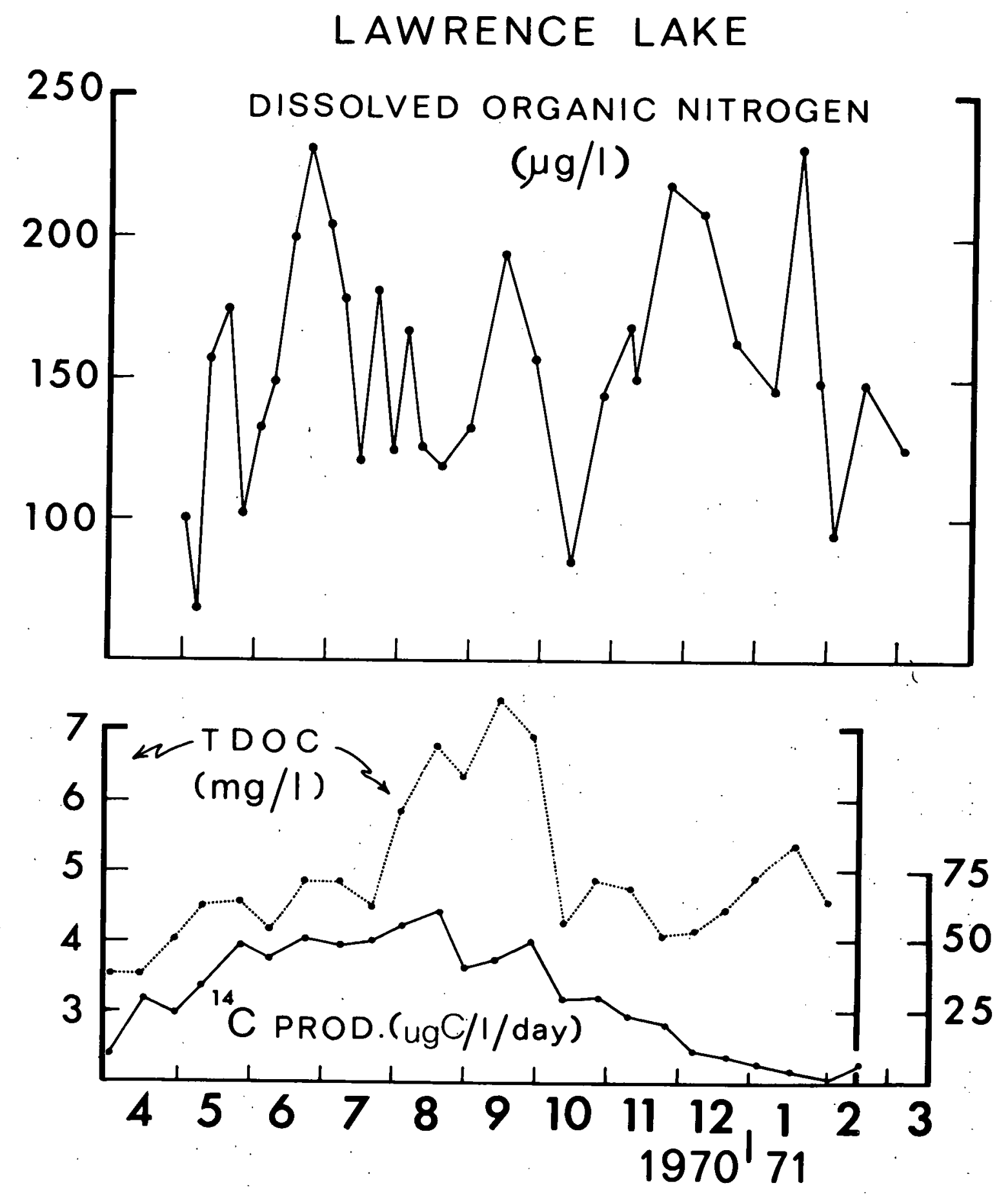


Figure 26. Annual changes in concentrations of LDON and RDON at $1 \mathrm{~m}$ depth in Wintergreen Lake from April 1970 to March 1971. 


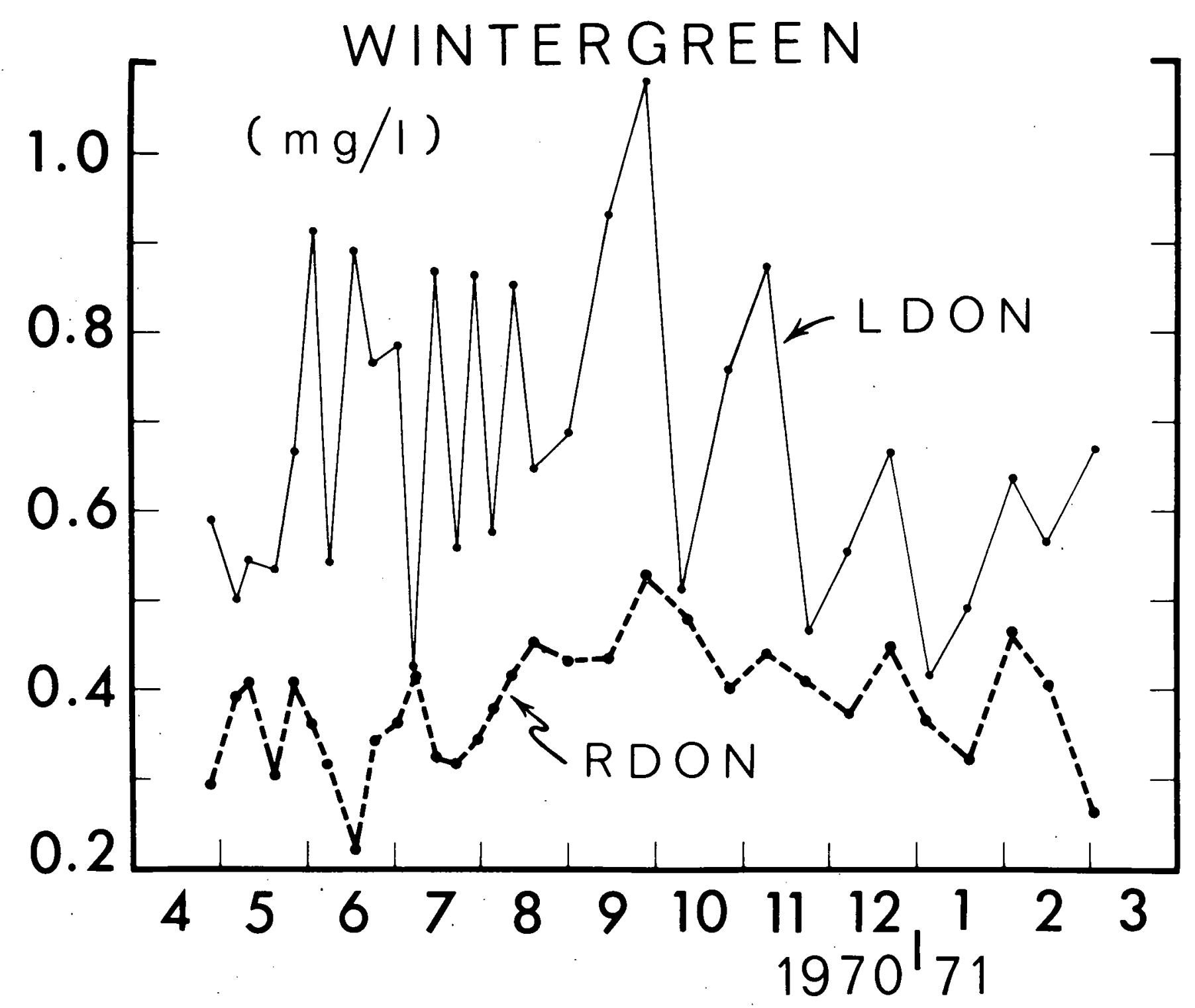


Figure 27. Correlation between total dissolved organic carbon and nitrogen (N = 7) at $1 \mathrm{~m}$ depth in Lawrence Lake from February to July 1970. Correlation does not include the datum from 4 August 1970 at right. 


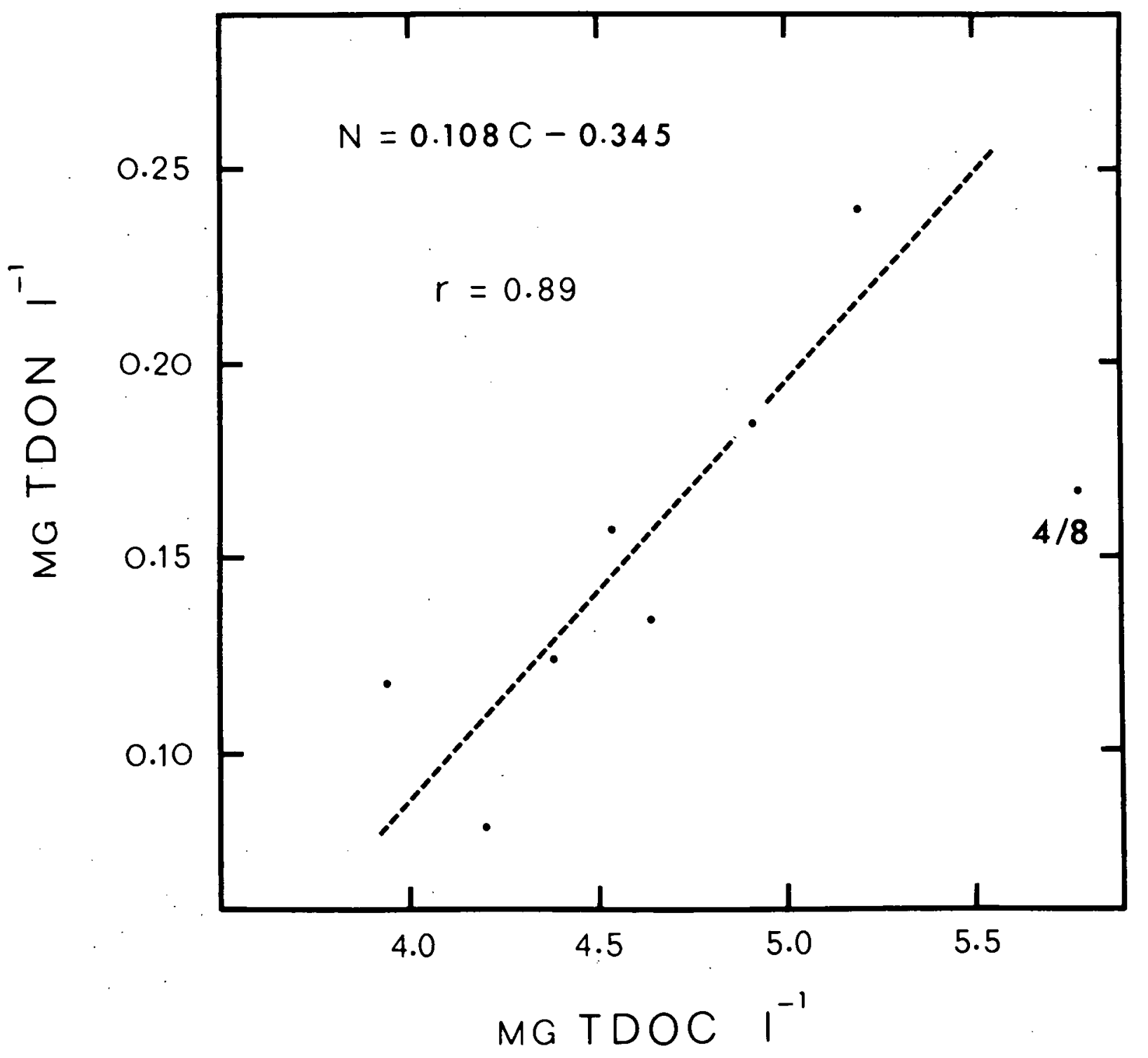


Figure 28. Total dissolved organic carbon and nitrogen data for $1 \mathrm{~m}$ depth in Lawrence Lake from February 1970 to February 1971, illustrating the lack of a consistent annual relationship. See text for explanation of square points with dates. 


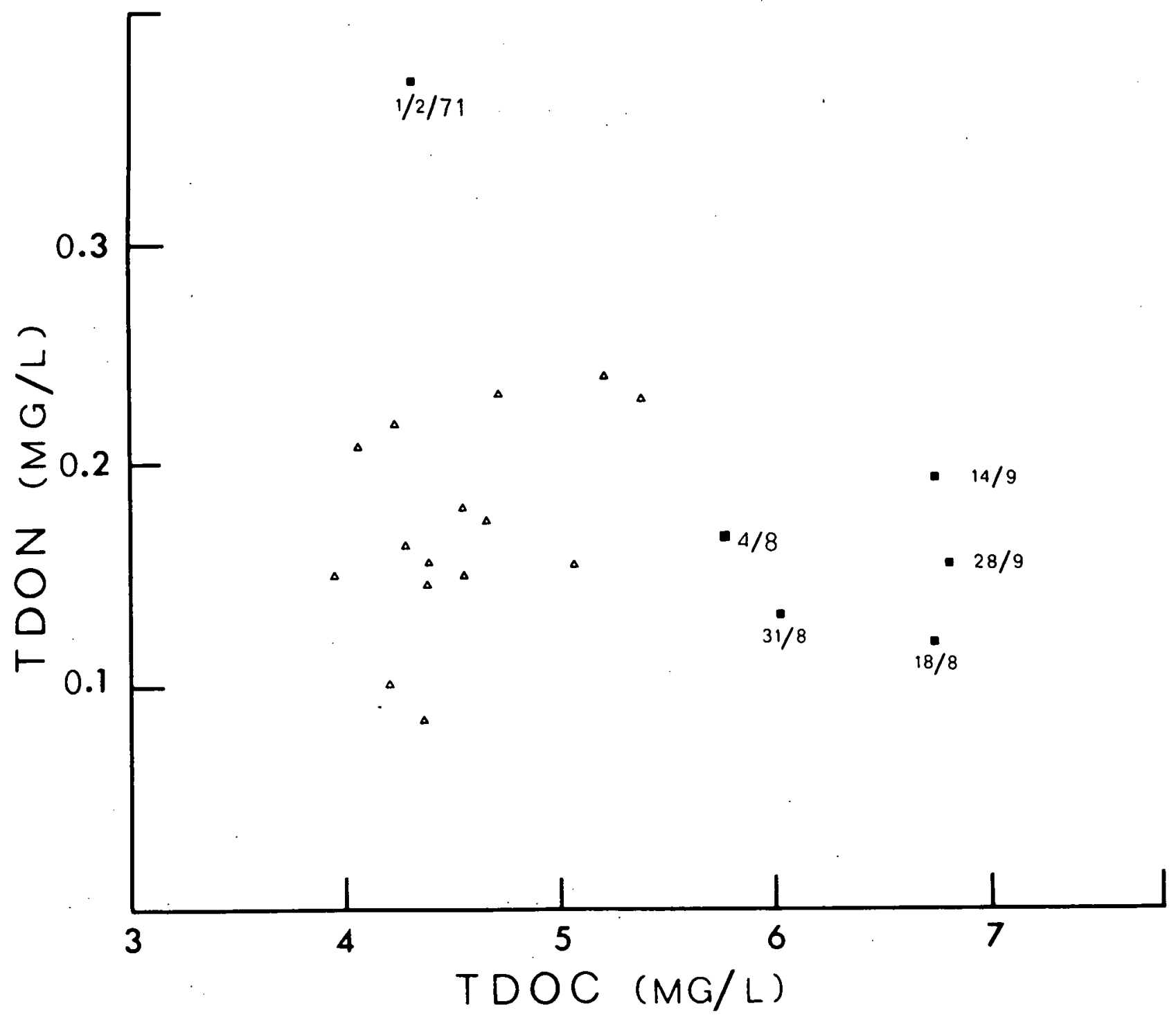


Figure 29. Comparison of annual changes in LDON and algal cell volume represented by members of the Chlorophyta and Chrysophyta larger than $10 \mu \mathrm{m}$ at $1 \mathrm{~m}$ depth in Lawrence Lake from May 1970 to March 1971. 

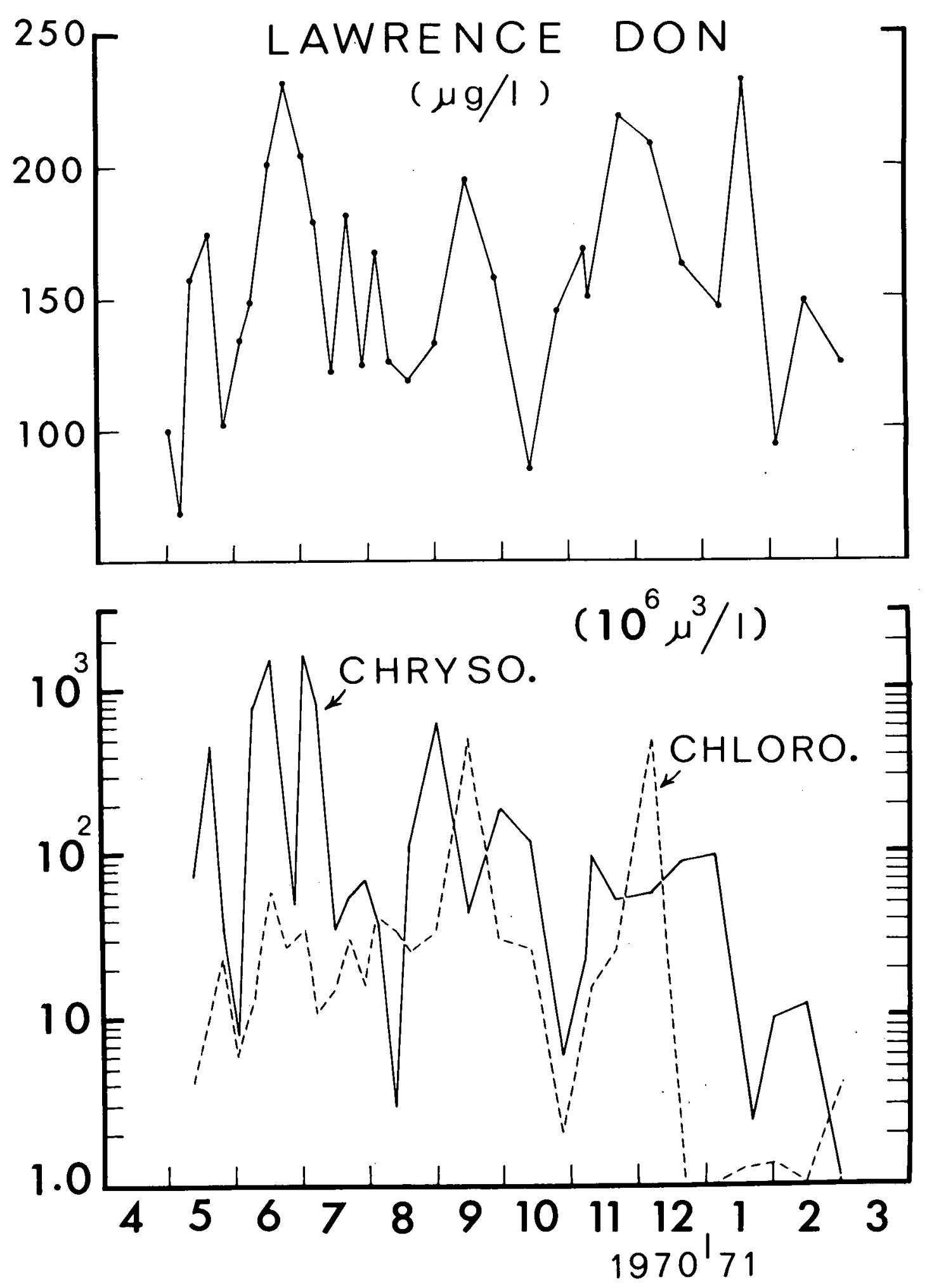
be a composite one; members of one phylum do not appear to be responsible for DON production or utilization. When no relationship could be found between DON and phytoplankton density, attention was directed to other possible DON sources. Zooplankton were ruled out on the basis of work by Johannes and Webb (1965), Webb and Johannes (1967, 1969) and Jawed (1969) which showed nitrogen is released by zooplankton largely as inorganic ammonia. Extensive work in progress on DOM release by aquatic macrophytes (Wetzel, 1969a, 1969b) and interactions between the littoral and pelagic zones (Wetzel and Allen, 1971) lead to consideration of DON production by aquatic macrophytes. This research soon indicated the littoral flora were the largest source of DON in Lawrence Lake (Wetzel and Manny, 1971). The second largest source of DON in Lawrence Lake on a projected annual basis was that contributed by allochthonous sources.

\section{Allochthonous DON}

The importance of allochthonous transport of inorganic nitrogen to lakes has been recognized for some time (Rawson, 1939; Deevey, 1940; Chandler and Weeks, 1944). Allochthonous nitrate is of major importance in the nitrogen cycle of Lawrence and Wintergreen lakes. Very few data exist for DON in rainfall. Parker (1968) has measured $\mu g$ quantities of vitamin $B_{12}$ in rain

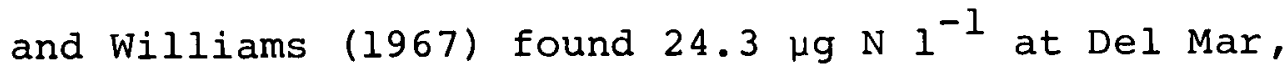


California and $23.1 \mu \mathrm{g} \mathrm{N} 1^{-1} 300$ miles north of Samoa. Williams concluded DON was probably insignificant in rainfall excepting marine localities where DON-rich surface films may be carried into the atmosphere.

The fate of organic nitrogen in streams has been studied using small recycling experimental streams. Yeast extract added to one stream disappeared more rapidly (1-5 days) than nitrate added to a replicate stream (18-20 days) (Ehrlich and Slack, 1969). Shortly after the yeast extract disappeared, a non-pigmented proteolytic pseudomonad bacterium increased greatly in abundance. At the same time, ammonia concentrations increased 10-fold. Within three weeks after nitrate or yeast extract addition, an initial periphyton of attached diatoms changed to filaments of Hormidium. Subsequently, a filamentous bluegreen alga appeared among the Hormidium in the stream to which yeast extract was added.

Mathews and Kowalczewski (1969) studied the disappearance of nitrogen from uniformly harvested packets of dried oak (Quercus robur L.), sycamore (Acer pseudoplatanus L.) and willow (Salix spp.) leaves in the River Thames. Nitrogen content of the packets increased initially if the leaves were protected by $0.27 \mathrm{~mm}$ mesh but nitrogen ultimately disappeared from the packets in the presence or absence of invertebrates. The increase in organic nitrogen was attributed to absorption of inorganic 
nitrogen from the Thames by colonies of microorganisms in the packets; the same interpretation was given by Hynes and Kaushik (1969). DON measurements were not made in either of these studies.

DON was measured twice in April 1971 in the six visible inflows contributing to Lawrence Lake, once in April 1971 at four stations in Augusta Creek (Barry and Kalamazoo counties, Michigan) at $2 \mathrm{~km}$ intervals below the Lawrence Lake discharge and twice during a four month experiment conducted by Drs. Cummins and Wetzel involving the release of dissolved and particulate organic matter from packets of oak (Quercus alba L.) and hickory (Carya glabra [Mill.]) leaves in two large, recycling, experimental streams.

\section{Allochthonous DON reaching Lawrence Lake passes} through fertile marshes underlain by Carlisle muck. Most of the water entering the lake either originated in springs or remained in the marshes after rainfall. At all times of the year, surface inflow volume is greatest and nearly equal at Stations $C$ and $D$ (Figure 30 ), reaching $31 /$ sec in the spring at Station $B$ (A. Otsuki, personal communication). LDON was observed to vary up to $50 \%$ of the values shown in Figure 30 at Stations A, B, E and 0 between 21 and 29 April 1971. Errors introduced by the necessary 20-fold dilution prior to nitrate measurement did not

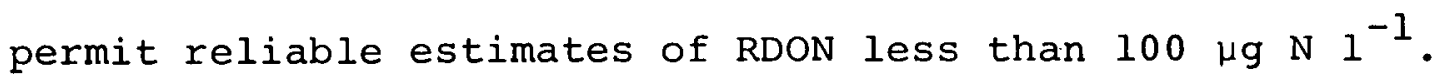


Figure 30. Average contributions of organic and inorganic nitrogen by visible allochthonous sources to Lawrence Lake during 21-29 April 1971. (A) Primary inflow from north marsh (B) Primary inflow from west marsh (C) Entrance of (A) into the lake (D) Entrance of (B) into the lake (E) Vernal spring (F) Deeply stained occasional inflow from northeast marsh (O) Outflow to Augusta Creek. 


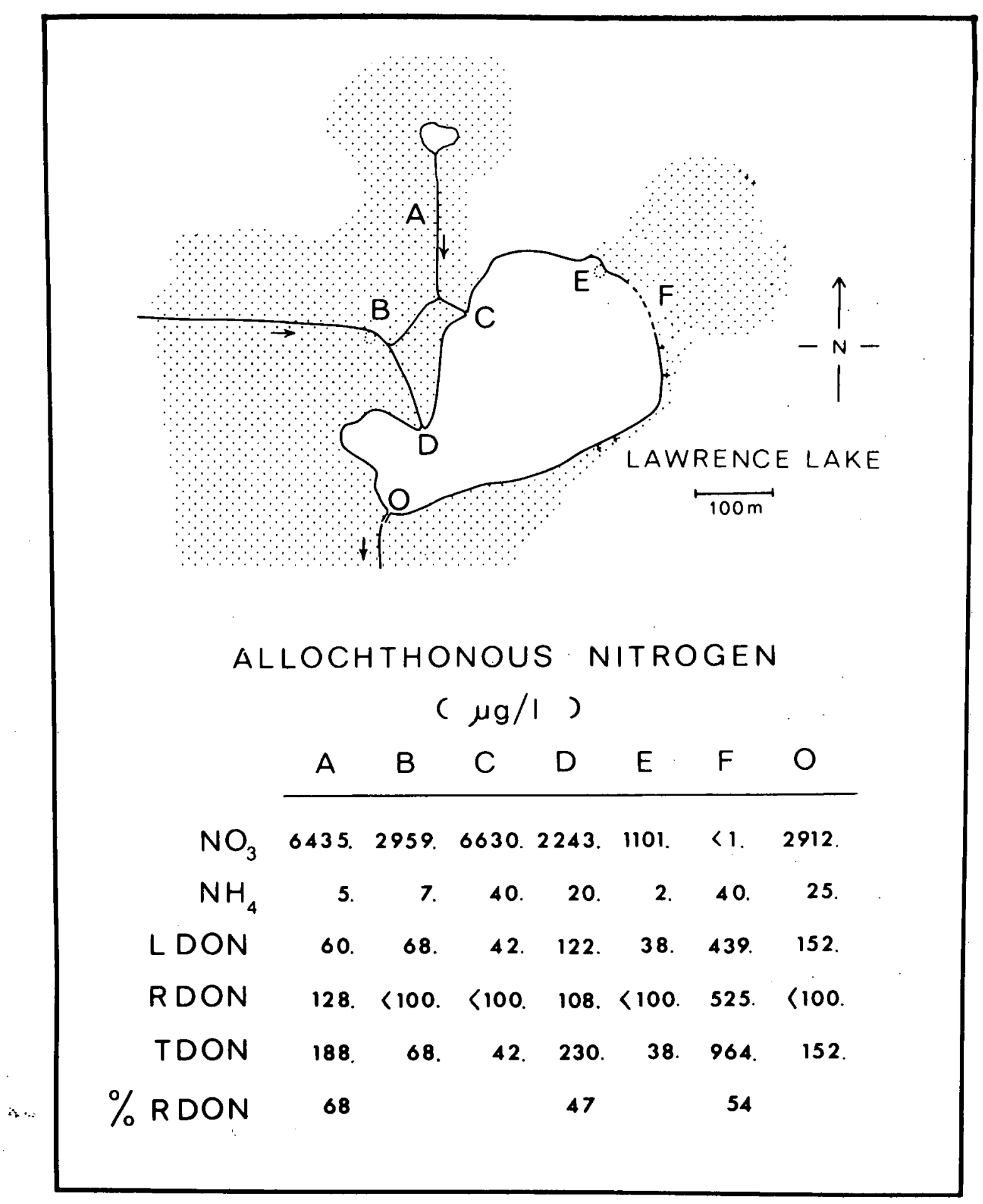


Nonetheless, it is clear little RDON entered Lawrence at stations other than $F$ on either date. Station F represents water that enters the lake only when the northeast marsh is flooded by rising lake levels. Particulate and dissolved organic matter from $F$ during such flushings may be momentarily significant in the northeast littoral zone but are rapidly removed after entry into the lake through combination with suspended monocarbonates (A. Otsuki, personal communication). Because the volume is small entering at F, contributions of RDON from $F$ are likely of minor importance to the DON budget of Lawrence Lake.

Concentrations of allochthonous LDON were less than LDON concentrations usually present at $l \mathrm{~m}$ in the center of Lawrence. Highest LDON appeared at Station D. TDON at all stations except $F$ were less than maximum levels during 1970 at $1 \mathrm{~m}$ in the center of Lawrence. Apparently, DON does not accumulate in Lawrence Lake.

Combustions of water from four stations in Augusta Creek below Lawrence Lake (Figure 31) revealed concentrations of LDON, RDON and TDON changed during transport downstream. LDON increased during passage through Hamilton Lake and a large marshy agricultural area between Stations $B$ and $C$ but decreased during transport down the main channel. RDON and TDON increased with distance downstream resulting in a progressive increase in percent RDON to $70 \%$ of TDON at Station $D$. These results indicate 
Figure 31. Organic and inorganic nitrogen concentrations on 24 April 1971 at several stations in Augusta Creek (Barry and Kalamazoo counties,

Michigan) below the Lawrence Lake discharge. Shaded areas represent extensive marsh lands. 


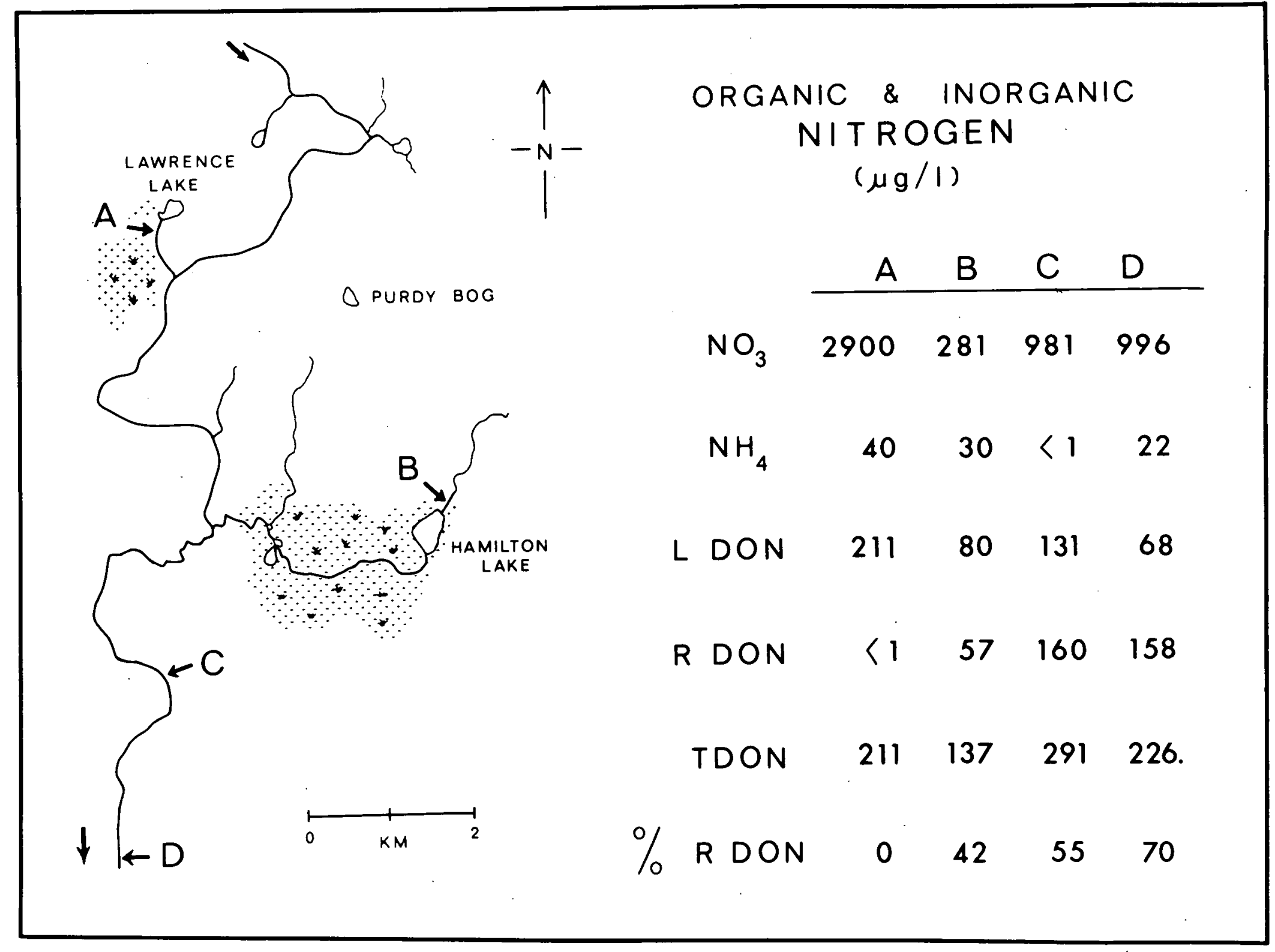


LDON is removed from the water while RDON accumulates in the water during transport downstream. Perhaps this RDON resembles the refractory melanoidin-like "humic compounds" not utilized by soil microflora (Manskaya and Drozdova, 1968).

It was possible to test whether RDON equilibrates at about $70 \%$ of TDON during downstream transport by combusting water from two experimental hardwater streams during a leaf decomposition experiment in a greenhouse. Samples were taken after 3 months when weekly measurements of TDOC provided by Dr. R. G. Wetzel indicated an apparent equilibrium in TDOC concentrations had been reached. The hypothesis was that percent RDON values would be representative of a steady state equilibrium condition likely present in natural hardwater streams during most of the year. Values of about $70 \%$ RDON were found in both streams (Table 6). One month later, dense growths of a filamentous green alga, Ulothrix, appeared in Stream 2 as solar irradiation increased in early May. Decreased nitrate concentrations coincided with the appearance of Ulothrix and LDON increased resulting in a lower percentage of RDON in TDON. Apparently, changes in the stream biota can alter the relative and absolute amounts of LDON and RDON in a stream. These changes were amplified in the experimental streams because water was continually recycled over the biota. 
Table 6. Concentrations of inroganic and organic nitrogen ( $\mu \mathrm{g} / \mathrm{l}$ ) after ultraviolet combustion of filtered water from two enclosed recycling experimental streams.

\begin{tabular}{lccccccc}
\hline \hline Date & Stream & $\mathrm{NO}_{3}$ & $\mathrm{NH}_{4}$ & LDON & RDON & TDON & RDON \\
\hline \multirow{2}{*}{ I April 1971 } & 1 & 83.0 & 15.0 & 34.0 & 73.0 & 107.0 & 68.2 \\
& 2 & 279.0 & 11.0 & 93.0 & 142.0 & 235.0 & 60.5 \\
19 May 1971 & 1 & 1 & 24.0 & 74.0 & 60.0 & 134.0 & 44.8 \\
& 2 & 1 & 3.0 & 112.0 & 47.0 & 159.0 & 29.6 \\
\hline
\end{tabular}




\section{Discussion of DON Results}

Seasonal DON changes in the six lakes appear to be individual. A high correlation observed initially between TDOC and TDON at $1 \mathrm{~m}$ depth in the six lakes (Manny et al., 1971) was not found in more frequent seasonal analyses at $1 \mathrm{~m}$ depth in Lawrence Lake. Differences between DON content of the six lakes appear to be related to the degree of littoral colonization and the magnitude of allochthonous DON entry relative to the volume of the lake. Because aquatic macrophytes release only LDON (Wetzel and Manny, 1971) small shallow lakes with basins highly colonized by aquatic macrophytes (e.g., Wintergreen, Purdy, and Duck) may be expected to have high LDON concentrations. Other small lakes with closed basins or high watershed area to surface area ratios (Purdy, Duck, Wintergreen) may be expected to have high RDON concentrations. Deeper, less productive lakes (Cassidy, Lawrence) and those fed largely by streams (Gull) may be expected to have low LDON concentrations and intermediate RDON concentrations, particularly if water entering the lake has been transported some distance. These views will undoubtedly be refined as more becomes known about: (1) rates of DON addition and removal during stream transport, (2) addition and removal by the littoral flora during passage of allochthonous DON into the pelagic zone, (3) amounts of each DON fraction produced by members of different 
phytoplankton phyla, and (4) in situ pelagic interactions contributing to DON utilization and removal to the hypolimnion.

Preliminary data from Augusta Creek and allochthonous sources entering Lawrence Lake indicate concentrations of LDON, RDON and TDON change during transport downstream. Apparently, an equilibrium exists between concentrations of LDON and RDON that is subject to constant modification by the stream biota.

Chlamydomonas moeuwsii and an unidentified,

coccoid phytoplankter isolated from Lawrence Lake (MCM \#7) produced DON that was 80-100\% LDON (Manny unpub1.). This result supports the hypothesis that LDON is largely of autochthonous origin whereas RDON is largely of allochthonous origin. Further measurements are needed to characterize (1) DON production by aquatic macrophytes, (2) DON interactions within the littoral zone, and (3) the relationship between UV and biological lability of DON.

Biological considerations as well as UV analyses indicate DON cycling is likely a most important--perhaps rate-limiting step--in the pelagic nitrogen cycle. Evidence presented above suggests DON in the pelagic zone is very dynamic biologically. More than 58\% of the DON produced by Scenedesmus was decomposed in 6 days by natural bacteria (Gocke, 1970). Only colloidal-N, serine, and 
glycine accumulated in lakes studied by Gocke (1970). However, amino, peptide and colloidal DON were present at all times in lake water. About $80 \%$ of the DON in the Pluss-See was present as peptide and colloidal-N (Brehm, 1967; Gocke, 1970). These compounds may be important in lake metabolism if they complex with plant nutrients. Various molecular weight DON fractions do complex with metals essential in plant metabolism (Fe, P, Mo, Mn, K, etc.). Biologically important nitrogenous, organo-metallic complexes known to form in natural waters include the avidity of bivalent alpha amino acids for the heavy metal ions in the order: $\mathrm{Cu}>\mathrm{Zn}>\mathrm{Co}>\mathrm{Cd}>\mathrm{Fe}>\mathrm{Mn}>\mathrm{Mg}$ (Albert, 1950, 1951, 1953; Duursma, 1968); the complexing of Mo and Fe by EDTA and NTA (Wetzel and McGregor, 1968; Skoog and West, 1969); the combination of polypeptide from Anabaena with $\mathrm{K}, \mathrm{Fe}, \mathrm{PO}_{4}$, and $\mathrm{Cu}$ (Fogg and Westlake, 1955) and the pH-dependent capacity of natural humic materials to bind with Fe (Shapiro, 1957, 1966a, 1966b; Kent and Hooper, 1965). Recently, Gelbstoff with an absorption spectrum "similar or identical to" that of humic materials from a bog and paper-pulp wastes has been synthesized by Sieburth and Jensen (1969) by reacting 2 parts Fucus polyphenol precursor with 4 parts each of proteins and polysaccharides present in seawater. Each of these organometallic complexes could modify the physiological environment of autotrophs in ways suggested by Saunders (1957) 
and Wetzel (1968). Because amino groups possess superior electron donor properties (Zabicky, 1968), DON containing tertiary amino groups, in particular, could be responsible for many DOM complexing responses known to suppress photosynthesis in hardwater lakes (Wetzel, 1969a).

Adsorption onto carbonate particles is likely an important vehicle in DON cycling in hardwater lakes. Although some information exists on precipitation (Pia, 1933; Wetzel, 1960; Walton, 1967), exact mechanisms responsible for crystal formation in complex solutions such as lake water are poorly understood. Because bacteria have a mucopolysaccharide coat closely analogous to organic matrices on which calcite and calcium phosphate crystals nucleate in other biological systems (Glimcher, 1960), they have been implicated in the process (Barber, 1966). Silicification by living diatoms and the formation

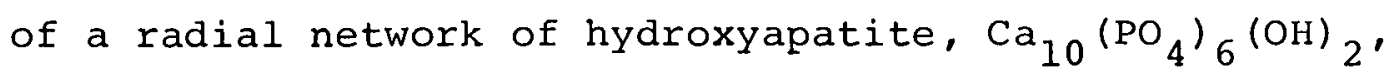
on the surface of the ciliate, Spirostomum ambiguum, growing in defined medium (Pautard, 1960) are known examples of crystal formation on microbial surfaces that may also occur in lake water.

Suspended monocarbonate particles rapidly adsorb amino acids (Wetzel and Allen, 1971) and larger proteins and polysaccharides (Chave and Suess, 1967, 1970) which may complex with trace metals (Matson, 1968), forestall solution of the carbonate and serve as substrates for 
bacterial metabolism (Khailov and Fineko, 1969). If adsorbed DON is utilized more rapidly than free DON, surface area provided by suspended carbonate particles may be an important factor in regulating pelagic DON cycling rates and accelerating nitrogen regeneration by bacteria. Moreover, loss of carbonate particles to the sediments would therefore be a likely route by which refractory DON reaches the hypolimnion. After a maximum colloidal diameter of about 0.1 to 1.0 micrometer is exceeded by the particles, they would begin to settle with their organic coating to the sediments.

If chemical and biological DON lability can be related, DON analysis by UV combustion may produce greater understanding of DON transport and cycling. In this approach, labile DON may act as a "short-circuit" in the conventional nitrogen cycle by acting as a direct intermediate between allochthonous nitrogen sources and lake autotrophs and acting as a reversible one-step intermediate between autotrophs or between autotrophs and bacteria in the lake (Figure 32 ). DON complexes with Fe, $\mathrm{PO}_{4}$ and other ions may delay loss of these ions to the sediments. These alternatives by-pass the conventional rate-limiting step of bacterial mineral release during decomposition of organic detritus and add perspective to the aquatic nitrogen cycle. 
Figure 32. Pelagic DON interactions and transformations. Heavier vectors indicate major pathways and potential regulatory mechanisms of aquatic photosynthesis in hardwater lakes. 


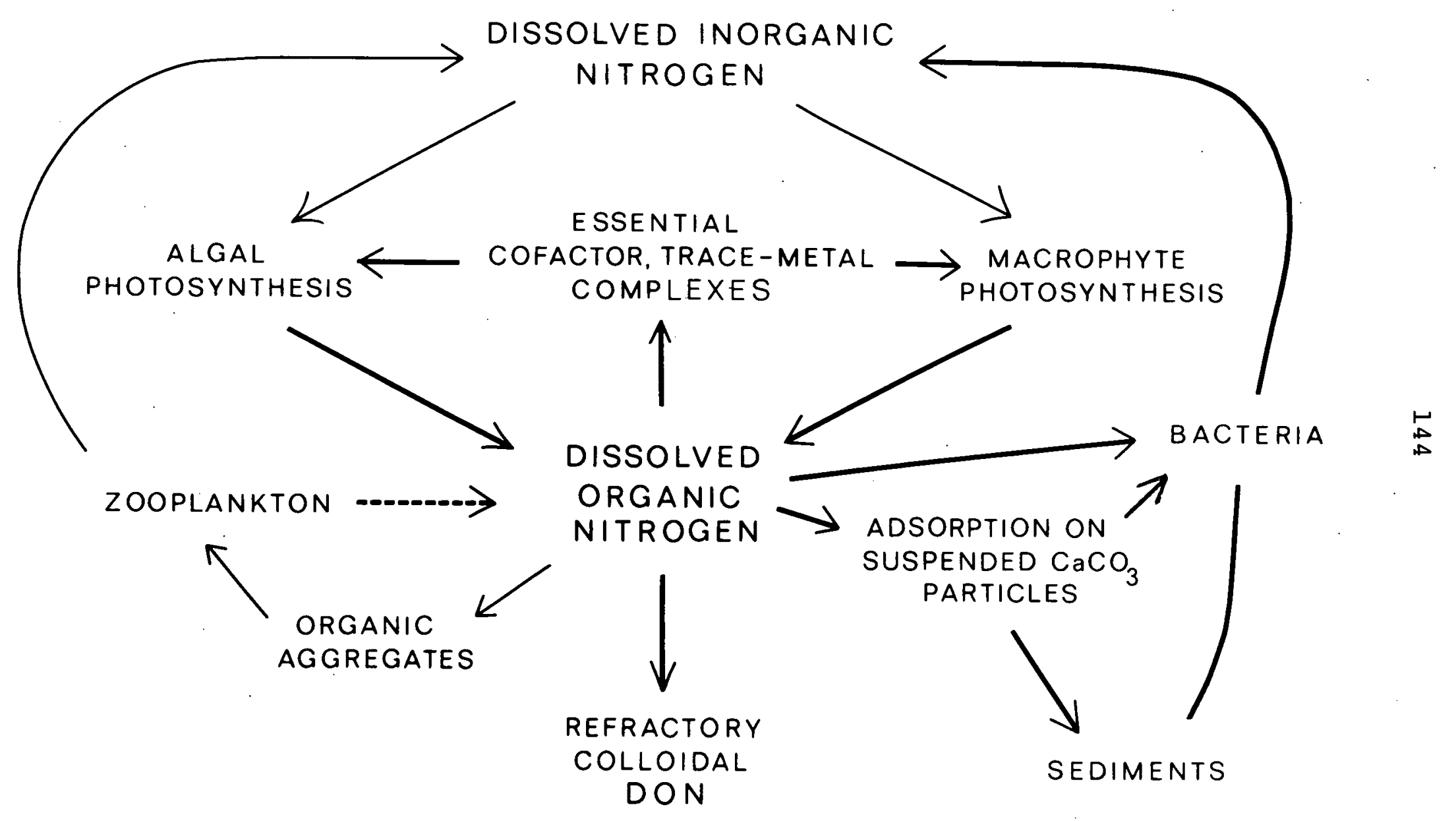


VII. GENERAL DISCUSSION

A. The Nitrogen Cycle in Lawrence Lake

Sustained high nitrate concentrations in Lawrence Lake are a consequence of two factors. Water entering the lake during most of the year probably originates in springs having high nitrate concentrations. Secondly, primary productivity in Lawrence is constantly inhibited by insufficient iron, phosphorus and a host of organic-inorganic interactions (Wetzel, 1971). Nitrate therefore accumulates in Lawrence because it is not utilized in proportion to the rate it enters the lake.

Before and after fall overturn, ammonia entered overlying waters from the sediments. Before fali overturn, high nitrite and ammonia concentrations were present between 7 and $12 \mathrm{~m}$ probably as a consequence of nitrate reduction. Nitrite accumulations at this time were probably caused by the different redox optima at which nitrate reducing bacteria function. Nitrate reducers reduce nitrite optimally at a potential of about $+475 \mathrm{mv}$; nitrite reducers reduce nitrite optimally at a potential of about $+25 \mathrm{mv}$ (Thimann, 1963). 
After overturn in the fall, nitrite accumulations were again present between 7 and $12 \mathrm{~m}$, perhaps for a different reason. During nitrification, nitrite probably accumulated as ammonia was oxidized by Nitrosomonas because Nitrobacter is inhibited by free ammonia ions (Thimann, 1963). After Nitrosomonas reduced ammonia levels sufficiently, populations of Nitrobacter probably developed and caused the maximum hypolimnetic nitrate concentrations observed during January between 10 and $12 \mathrm{~m}$ (Figure 10).

Under the ice, density differences were greatly reduced relative to those present during summer stratification. This reduced density gradient may explain the more complete equilibration of hypolimnetic nitrate concentrations under the ice relative to summer conditions. Warmer sediments beneath the water column under the ice probably aided in distributing hypolimnetic accumulations of nitrate and ammonia by giving rise to vertical convection and eddy diffusion currents.

In the spring, inorganic nitrogen may have been rapidly converted to organic nitrogen because increased solar radiation and water temperatures created favorable conditions for phytoplankton growth. During March and April 1970, a mixture of chlamydomonads and later larger diatoms increased in number as ammonia concentrations at $1 \mathrm{~m}$ decreased to minimal levels $(<15 \mu \mathrm{g} / \mathrm{l})$. Nitrate 
continued to increase at $1 \mathrm{~m}$ during this period because large volumes of nitrate-rich water entered the lake with spring run-off and because ammonia was probably utilized in preference to nitrate by the phytoplankton.

As the lake became thermally stratified, exchange between the epilimnion and hypolimnion was greatly reduced. Hypolimnetic dissolved oxygen and $\mathrm{pH}$ rapidly decreased, perhaps owing to bacterial decomposition of sediments resuspended during overturn. As dissolved oxygen and $\mathrm{pH}$ reached minimum levels, conditions became favorable for nitrate reduction again.

Significant deviations from this highly regular annual sequence may occur in Lawrence during years when wind energy is not sufficient to disrupt thermal stratification. During the resultant temporary meromixis, oxygen and $\mathrm{pH}$ would rapidly decrease in the hypolimnion and intensify nutrient regeneration during the summer stagnation period. Higher epilimnetic productivity might be expected during such years after fall overturn when the normal annual sequence would be reestablished.

The normal annual sequence in Lawrence Lake resembles Hutchinson's (1941) description of a Phase I trophic equilibrium condition. The sequence should continue until the mean depth in Lawrence decreases to a point where other factors (below) come into play. An alternative to this developmental pathway might take the 
form of regression from Phase I conditions to permanent meromixis during a year when neither spring nor fall mixing are complete. Iron and phosphorus might then accumulate in the monimolimnion indefinitely (Kjensmo, 1968). Epilimnetic productivity would probably be related to rates of iron and phosphorus entry from the watershed. This alternative may be viewed as a deacceleration of eutrophication. Recent evidence supports the view that development of lakes is not from oligotrophy to eutrophy (Hutchinson et al., 1970; Wetzel and Allen, 1971).

Normal annual events in Wintergreen resemble those in Lawrence but occur more rapidly and with greater intensity. Rapid development of complete hypolimentic anoxia four weeks after vernal overturn and less well developed thermal stratification over much of the basin probably permitted more ammonia and nitrate to reach the epilimnion. In winter, greater sediment-water temperature differences (compared to Lawrence) correlated with more rapid ammonia and nitrate redistribution throughout the water column beneath ice cover.

In the spring, Wintergreen received ammonia, nitrate and phosphorus from six visible allochthonous sources and probably two unmeasured sources--nitrates generated by bacteria in adjacent cornfields and melting ice upon which great quantities of duck and goose excrement had accumulated. The organic load from the latter 
source enters the lake twice annually in spring and during the fall; likely this organic load intensifies rapid hypolimnetic decreases in oxygen and pH after overturn.

\section{B. Role of Carbonate Particles}

That carbonate particles exist in hardwaters can no longer be reasonably discounted, however, their role in lake metabolism remains to be demonstrated. For example, it is unknown whether carbonate particles in lakes are coated with nitrogen-rich materials. If present for most of the year in Lawrence and Wintergreen, such particles provide one explanation for the consistently high nitrogen content of nannoseston. Because labile DON has been shown to adsorb rapidly to carbonate particles in lake water in the laboratory, it is very likely carbonate particles remove DON from the epilimnion as it is produced or as it enters the lake, perhaps during passage through the littoral zone.

Another important role suggested by the present study is one played by carbonate particles in nitrate reduction and ammonia nitrification. Bacteria in lakes are usually present in greatest numbers in the hypolimnion where they readily adsorb to organic and inorganic surfaces (McCoy and Sarles, 1969; Henrici, 1936). Attempts made to isolate nitrifying bacteria were unsuccessful for many years until Winogradski (1890, 1891 in Thimann, 1963) developed a successful technique using inoculations from 
small floccules attached to $\mathrm{CaCO}_{3}$ particles removed from a lake. Subsequent work showed Nitrosomonas and Nitrobacter were highly sensitive to changes in $\mathrm{pH}$ and that they required calcium in nitrification. In culture, $\mathrm{pH}$ control and $\mathrm{Ca}$ requirements may be met by providing solid $\mathrm{CaCO}_{3}$. These facts suggest carbonate particles may be involved in nitrification of ammonia in the hypolimnion of hardwater lakes.

\section{Role of Dissolved Organic Compounds}

Wetzel (1965-71) has demonstrated dissolved organic matter (DOM) can complex with trace metals, $\mathrm{Fe}$ and $\mathrm{P}$; alter monovalent to divalent cation ratios; adsorb on colloidal and particulate carbonates; and accelerate bacterial metabolic rates in hardwater lakes. In addition, DOM may influence DON removal rates from the epilimnion to the hypolimnion.

Direct evidence for DOM coatings on carbonate particles is limited to work by Chave and Suess (1969), Suess (1969), Chave (1970) and Wetzel and Allen (1971). Sustained absence of increases in dissolved total phosphorus in Lawrence Lake, compared to the sustained high levels in Wintergreen, suggest a carbonate-like mechanism present in Lawrence has somehow been deactivated in Wintergreen. In addition, Wetzel (1971) showed orthophosphate quickly precipitated as $\mathrm{Ca}_{3}\left(\mathrm{PO}_{4}\right)_{2}$ and $\mathrm{FePO}_{4}$ when added to Lawrence Lake water at room temperature. 
If a non-nitrogenous fraction of the DOM pool deactivates carbonate particles by coating them, that fraction would more likely be present in Wintergreen because DOM of all kinds is renewed twice annually in wintergreen in the form of waterfowl excrement.

UV absorption and fluorescence data (Miller, 1971) indicate much of the DOM in Lawrence Lake is very old (> 1 year and < 100 years) and perhaps composed largely of inactive humic materials. Absorption and fluorescence profiles in the two lakes show fluorescent humic materials accumulate near the bottom of Lawrence whereas such compounds decrease with depth in Wintergreen. This difference in distribution suggests greater amounts of "younger" possibly more labile DOM may be present in the epilimnion of Wintergreen Lake. Hence, there is increased probability compounds capable of deactivating carbonate particles are present in Wintergreen.

Carbonate particles and organic coatings on carbonate particles appear to form at different rates depending upon the type of organic compounds present and $\mathrm{pH}$ (Suess and Chave, 1969; Chave, 1970). At very high concentrations $(1-10 \mathrm{~g} / 1)$, many organic compounds reduce the rate of particle formation (Kitano, Kanamori and Tikuyama, 1970). Newly formed particles are coated within minutes in seawater (Chave, 1970) and Lawrence Lake water (Wetzel and Allen, 1971). Should similar processes occur in Wintergreen, coatings might form rapidly enough to keep pace with 
particle nucleation, perhaps retarding DON removal from the epilimnion.

D. The Phosphorus Cycle in Hardwaters

In hardwaters, phosphorus quickly adsorbs to suspended colloids and particulate carbonates (Gessner, 1939; Ohle, 1935, 1937). By raising the pH of natural water from Lawrence Lake, Otsuki and Wetzel (1971) demonstrated coprecipitation of more than 758 of added ${ }^{32} \mathrm{P}$ tracer within five minutes. These results strengthen years of field observations during which annual changes in total dissolved phosphorus have not occurred at any depth in Lawrence Lake. Only trace amounts $(<10 \mu \mathrm{g} / 1)$ of dissolved total phosphorus have yet been measured at any depth in Lawrence, even during overturn (Wetzel, 1971, Figure 1). One might conclude from these data that all phosphorus entering Lawrence Lake quickly adsorbs to colloidal and particulate carbonates and is eventually lost to the sediments. Phosphorus analyses of sediments in a core from Lawrence Lake would likely show little change with depth in the sediments unless rates of phosphorus entry into Lawrence Lake changed markedly at some point in the past.

Dissolved and particulate total $\mathrm{P}$ in Wintergreen Lake underwent a seasonal cycle at all depths. In the spring, the entire lake was apparently saturated with phosphorus because dissolved phosphorus entering the lake was not removed during passage through the lake. These 
observations suggest phosphorus in wintergreen either enters the water column in the spring at rates equal to or greater than rates with which it is removed or, colloidal and particulate carbonates, if formed, have been deactivated by organic coatings.

E. Seston Fractionation

Perhaps the most interesting result to be drawn from this aspect of the study was that more than half of all nitrogen, chlorophyll, and algal cell volume in both lakes was present more than half the year in the nannoseston and nannophytoplankton. This result does not agree with early comparisons of net and nannoplankton nitrogen content in Lake Mendota (Birge and Juday, 1922). They found less nitrogen in the nannoseston on a dry weight basis. The disagreement probably lies in the primitive separation techniques (centrifugation) used in this early work.

The fractionation results provide strong evidence for Pavoni's (1963) hypothesis that nannoplankton dominate algal biomass in lakes at both extremes of the trophic spectrum. This conclusion might now be expanded to read that nannoplankton dominate nitrogen transformations in lakes at both extremes of the hardwater trophic spectrum. These same results support the suggestion that "in more eutrophic situations the larger organisms assume greater significance" (Wetzel, 1964); nannosestonic-N dominance of 
the total sestonic- $N$ was sustained for fewer months in Wintergreen than in Lawrence.

Relative to other earlier observations, nannoplankton dominance of organic nitrogen production in both lakes supports the many observations that nannoplankton are responsible for a majority of ${ }^{14} \mathrm{C}$-fixation (Rodhe, Vollenwider and Nauwerck, 1958; Holmes and Anderson, 1963; Wetzel, 1964, 1966) and comprise a major portion of the plankton biomass (Banse, 1961), algal cell volume (Willen, 1959, 1961), cell numbers and chlorophyll content (Yentsch and Ryther, 1958). It is becoming increasingly apparent that methodology based upon net concentrations of the seston underestimate the parameter in question considerably. This point was made very clear by comparing retention of sestonic nitrogen and chlorophyll on conventional $65 \mu \mathrm{m}$ \#25 "fine" Nitex netting, $10 \mu \mathrm{m}$ Nitex netting and glass. fiber filters of about $0.3 \mu \mathrm{m}$ porosity. Results (Table 7) showed either netting is completely inadequate for obtaining representative values of sestonic-N or chlorophyll. If seston must be concentrated, only filters of porosity less than $0.5 \mu \mathrm{m}$ should be used. This porosity will pass little sestonic-N or chlorophyll.

Sestonic-N in both lakes and the Wintergreen chlorophyll data are compatible with the hypothesis that nannophytoplankton are rich in nitrogen and chlorophyll relative to the netphytoplankton. This result may have 
Table 7. Percentage retention of total sestonic nitrogen and uncorrected chlorophyll a upon sample passage through $65 \mu \mathrm{m}$ and $10 \mu \mathrm{m}$ Nitex filter cloth. Values are means of duplicate trials using raw water from wintergreen Lake.

\begin{tabular}{|c|c|c|c|c|c|}
\hline & \multirow{2}{*}{ Date } & \multicolumn{2}{|c|}{$10 \mu \mathrm{m}$ Nitex } & \multicolumn{2}{|c|}{$65 \mu \mathrm{m}$ Nitex } \\
\hline & & $N\left(\frac{8}{8}\right)$ & $\operatorname{Chl}\left(\frac{\circ}{8}\right)$ & $N(\%)$ & $\operatorname{chl} 1-\mathrm{a}(\%)$ \\
\hline 30 & October 1969 & 57.8 & 77.8 & 33.5 & 30.0 \\
\hline 5 & November 1969 & 25.7 & 35.0 & 15.9 & 5.3 \\
\hline 13 & November 1969 & 58.5 & 39.6 & 19.1 & 3.8 \\
\hline 20 & November 1969 & 38.0 & 21.8 & 26.4 & 2.5 \\
\hline \multirow[t]{2}{*}{26} & November 1969 & 26.3 & 13.2 & $\underline{16.4}$ & 4.4 \\
\hline & Average: & 41.3 & 37.5 & 22.3 & 9.2 \\
\hline
\end{tabular}


important implications in zooplankton feeding studies and it explains in part why spring increases in zooplankton are linked with increases in nannophytoplankton abundance (Haney, 1970; O'Brien, 1970). During zooplankton increases, the nannophytoplankton are likely grazed more than larger forms, particularly Cyanophyta, which are less digestible (Arnold, 1970) and less nutritious (present study).

Selective removal of the nannophytoplankton by zooplankton in the spring may explain why larger phytoplankton become progressively more abundant than nannophytoplankton in late spring. Another less likely explanation for the relative increase in netphytoplankton in late spring is competition for available nutrients between net and nannophy toplankton.

Margalef (1968) suggested that exploitation of the phytoplankton by zooplankton during early stages of phytoplankton succession gives evolutionary advantage to the zooplankton. One of the problems of this argument was that it did not explain why zooplankton had not evolved to a point where they could adapt to the spring switch from small to large phytoplankton abundance by assuming a macrophagous habit (Margalef, 1968; p. 76). If nannophytoplankton are consistently nitrogen-rich relative to netphytoplankton, zooplankton would gain no nutritional advantage by adopting a macrophagous habit. 


\section{F. Wintergreen Lake Spring \\ Phytoplankton Bloom}

The most dramatic nitrogen transformation in Wintergreen Lake was an explosive spring bloom of Chlamydomonas under the ice during which dissolved ammonia was converted quantitatively to sestonic-N. From February to mid-April 1970, ammonia decreased from $1800 \mu \mathrm{g} / 1$ to $15 \mu \mathrm{g} / 1$ while nitrate continued to increase. From midApril to 8 June 1970, nitrate decreased from $1320 \mu \mathrm{g} / 1$ to $5 \mu \mathrm{g} / 1$ coincident with the latter part of a mixed Chlamydomonas-Cryptomonas bloom and rapid development of macrophyte beds over much of the basin.

Factors causing the spring bloom in Wintergreen are likely the same as those contributing to similar explosive blooms in Smith Lake, Alaska. For the past 10 years, prior to ice-off in June, a massive bloom of mixed Chlamydomonas, Euglena and Chlorella has developed that converted about $300 \mu \mathrm{g} / \mathrm{l}$ ammonia into sestonic-N (Billaud, 1967, 1968). Billaud and others have suggested such blooms result from increased solar radiation, high concentrations of ammonia and rapidly rising temperatures under the ice. Subsequent events in Smith Lake resemble those in Wintergreen Lake during 1970. Immediately after ice breakup, a bloom of Anabaena flos-aquae developed which extended the precipitous rise in sestonic- $N$ by nitrogen fixation and nitrate assimilation, much as Cryptomonas did in Wintergreen Lake (excepting nitrogen fixation). After 
the Anabaena bloom in Smith Lake and the Cryptomonas bloom in Wintergreen Lake, Aphanizomenon became the dominate form in both lakes. These similarities and more recent data in 1971 suggest the spring bloom in Wintergreen is an annual event.

Why ammonia was utilized in the presence of high nitrate concentrations deserves further comment. Ammonia is assimilated by phytoplankton in preference to nitrate under many different conditions. For example, ammonia is assimilated from equal or greater concentrations of nitrate (Prochazkova, Blazka and Kralova, 1970) in both the light (Syrett, 1962) and the dark (Fitzgerald, 1968, 1969). Normally, nitrate assimilation occurs only after a period of acclimatization (Goering et al., 1964) if the enzyme responsible (nitrate reductase) is not repressed by ammonia (Morris and Syrett, 1964), amino acids (Filner, 1966), calcium ions (Harper and Paulsen, 1969a) or deficiencies of other ions (Harper and Paulsen, 1969b). The process of ammonia uptake itself may alter the ionic balance of the boundary membrane and cause decreased membrane permeability to nitrate (Minotti et al., 1969). MacIsa ac and Dugdale (1969) and Eppley and Rogers (1970) have shown uptake of ammonia by marine phytoplankton is much more rapid than nitrate uptake under natural conditions.

Other factors likely involved during the spring bloom in Smith and Wintergreen lakes are (1) the promotion 
of protein synthesis over carbohydrage and lipid synthesis in Chlorella by low light intensities (Taub and Dollar, 1965), (2) ammonia excretion by members of a declining bloom (Billaud, 1968; Prochazkova et al., 1970), and (3) ammonia regeneration within the water column from DON (Dugdale and Goering, 1967).

Very likely the spring bloom from February to May in wintergreen is a period of high productivity rates during which, a large share of the annual primary productivity takes place. In Sylvan Lake, Indiana, Wetzel (1966) found $25 \%$ of the annual carbon productivity occurred during a similar bloom under the ice.

\section{G. Nitrogen Limitation}

Mixed populations of Aphanizomenon, Microcystis and Aphanothece dominated the phytoplankton in Wintergreen at $1 \mathrm{~m}$ depth during July and August 1970. Because ammonia and nitrate were nearly unmeasurable for much of this period (Figure 9) one might ask why these blue-green algae were so abundant. One hypothesis suggests that Aphanizomenon dominates when annomia and nitrate are absent because it can fix atmospheric nitrogen. High $\mathrm{N}$-fixation rates measured during this period support this hypothesis (T. Duong, unpubl.). Another hypothesis holds that bluegreen algae dominate during periods of high DON concentration (Pearsall, 1932). Maximum LDON and RDON concentrations did appear in Wintergreen during July and August 
1970 but the correlation may be explained by high DON production by blue-green algae. Fogg and Westlake (1955) showed a large amount of polypeptide was produced by Anabaena cylindrica in culture. This observation suggests blue-green algae cause high DON concentrations, not the reverse.

Perhaps a more satisfactory explanation for dominance by blue-green algae in late summer in productive lakes lies in their combined abilities to (1) store excess nitrogen and phosphorus, (2) create within themselves gas vacuoles, (3) grow better in culture at low light intensities (< 100 ft-cand.) than at high light intensities $(8,000$ to $10,000 \mathrm{ft}$-band.), (4) escape being grazed by zooplankton (Arnold, 1969), and (5) undergo diurnal migrations (Fitzgerald, 1969) sinking at night into nutrient-rich waters and returning to the surface the following morning. Bella (1970) recently showed algae with low sinking rates (exemplified by blue-green algae) would remain longest near the surface during calm, late summer weather.

Billaud (1968) and others have noted blue-green algae in surface blooms rapidly lose their viability. If they were growing well at the surface in low nitrogen concentrations they should not rapidly expire. Secondly, Microcystis aeruginosa was observed in Wintergreen throughout July and August 1970 yet Gerloff and Skoog (1957) 
argued that it should be unable to grow in less than milligram/l nitrate concentrations. None of these observations are conclusive, they only serve to illustrate we know little about nitrogen limitation in natural populations of blue-green algae.

\section{H. Lake Metabolism and Eutrophication}

Previous results and discussion illustrate many ways in which organic and inorganic nitrogen interact to accelerate and repress biological activity in hardwater lakes. The summation of biological rates in a lake comprise the metabolic rate. Over extended time, the summation of annual chemical and biological rates in a lake define the eutrophication rate. Should one interaction or class of interactions consistently control one or more chemical or biological rates in a class of lakes, that interaction may be expected to govern rates of eutrophication within that class of lakes.

Most organic nitrogen produced in or entering hardwater lakes is recycled as inorganic nitrogen by hypolimnetic bacteria. Several factors may interact to control this transformation in dimictic hardwater lakes. For example: (1) entrance rates of organic carbon and nitrogen, (2) hypolimnetic oxygen content, (3) hypolimnetic temperature, (4) hypolimnetic $\mathrm{pH}$ and overall buffering capacity, and (5) organic-inorganic interactions affecting a) availability of the organic-N, b) membrane 
permeability of the bacteria and availability of other essential nutrients (vis. phosphorus).

A combination of these factors likely to result in slow eutrophication rates would be: (1) small, steady entrance rates of dissolved and particulate carbon and nitrogen; (2) an unsheltered, deep basin in which spring and fall mixing are always complete; (3) low hypolimnetic temperatures; (4) well-buffered water of $\mathrm{pH} 8.0$; and (5) a saturated bicarbonate-carbonate buffer system conducive to continuous generation of carbonate nuclei around photosynthesizing algae and macrophytes. As DON entered this system, it would adsorb onto the carbonate particles, perhaps during passage through the littoral zone, and be carried eventually into the hypolimnion to be slowly transformed to ammonia by small bacterial populations present there. As the DON-coated carbonate particles settled into the hypolimnion, essential trace metals and micronutrients such as $\mathrm{Fe}$ and $\mathrm{P}$ might complex with the coatings and be removed from the water column. Maximum DON entry would likely occur during summer after macrophytes in the basin have developed full photosynthetic capacity and in the fall when high rains carry residues of fallen leaves to the lake.

A combination of these factors likely to result in rapid eutrophication rates would be: (1) high entrance rates of organic carbon and nitrogen; (2) a shallow, 
sheltered basin in which mixing is seldom complete; (3) high hypolimnetic temperatures summer and winter; (4) poorly buffered water in which hypolimnetic $\mathrm{pH}$ is quickly lowered below 8.0 by high sustained bacterial activity; and (5) an unsaturated, poorly buffered bicarbonatecarbonate system rarely conducive to carbonate particle formation and in which newly generated carbonate nuclei are quickly coated with organic matter. DON entering this system would probably accumulate in the epilimnion because no carbonate particle mechanism exists to transport it through metalimnetic density gradients into the hypolimnion.

Conditions in Lawrence Lake approximate the first example but differ in that Lawrence has a low surface area to volume ratio and is somewhat sheltered such that mixing is sometimes incomplete. Another difference is that $\mathrm{P}$ and Fe are rarely available above the sediments.

Conditions in Wintergreen Lake approximate the second example but differ in that Wintergreen is well mixed and rather well buffered. There is little question that macrophytes dominate all facets of lake metabolism in Wintergreen.

During late summer and winter, the hypolimnion and the entire lake are a closed system, respectively. Nursall's (1969) discussion of allochthonous versus autochthonous impact on energy and materials transformations in a closed system describes the lake biota as an 
open system within a closed system, during the winter. Because the biota are opportunistic and variable, they capitalize on favorable changes in energy and materials entering or generated within the lake. Nursall states that the biota is predictable only under strongly limiting conditions or in the special case of a well-defined high rate of materials entry into the lake. Future data from Lawrence and Wintergreen lakes will likely support Nursall's ideas. Both lakes fit very well within his descriptions. For example, plant growth in Lawrence is rigorously limited by a host of organic and inorganic interactions. In return, the biota are rather predictable. The biannual loading of Wintergreen place it in the special case category. One might expect the spring bloom in Wintergreen to be an annual event.

Lastly, eutrophication rates among hardwater lakes likely differ depending on whether control of primary productivity lies within or outside the lake basin. Conditions within or outside Lawrence and Wintergreen lakes counterbalance deviations in chemical and biological parameters in a manner analogous to a room thermostat. Control horizons about the Wintergreen biota are much wider than those about the Lawrence biota. Greater responses result when conditions change within or outside Wintergreen. Nearly all biological responses in Wintergreen were more rapid and of greater duration than their 
counterpart in Lawrence. Lawrence appears to be controlled from within by its bicarbonate system whereas wintergreen appears to be controlled by external seasonal changes in light and materials entry.

Examples serving this distinction are the chronic shortage of $\mathrm{Fe}$ and $\mathrm{P}$ in Lawrence and the explosive spring phytoplankton bloom in wintergreen in response to increased light, temperature and nutrients. The former shortages likely controlled both lakes beginning shortly after their inception but became inoperative in Wintergreen when its mean depth decreased to a point where hypolimnetic oxygen concentrations were insufficient to oxidize organic matter entering the basin. At this point, rates of energy and materials cycling began to increase producing occasional years of higher productivity between periods of lower productivity. With timber removal in Michigan around 1825 (Davis, 1971), and with increased waterfowl usage since 1928, materials entering Wintergreen Lake accelerated markedly. As a function of long residence times for water entering the basin, materials have accumulated within the lake to a point where cycling rates of energy and materials are 10 to 100 times faster than the same transformations in Lawrence Lake.

If the watershed were planted with timber, the effluents diverted, and the waterfowl excluded, Wintergreen would probably revert rapidly to a less productive state. 
Under the present conditions, production and cycling rates during the spring bloom likely represent maximum rates in this latitude. 
REFERENCES 


\section{REFERENCES}

Ahlstrom, E. H. and J.R. Thrailkill. 1961. Plankton volume loss with time of preservation. Cons. Perm. Int. Exp. Mer. Rapp. Proc. Verb. Reun. $153: 78$.

Albert, A. 1950. Quantitative studies of the avidity of naturally occurring substances for trace metals. I. Amino acids having only two ionizing groups. Biochem. J. $47: 531-538$.

- 1952. Quantitative studies of the avidity of naturally occurring substances for trace metals. II. Amino acids having three ionizing groups. Biochem. J. $50: 690-698$.

- 1953. Quantitative studies of the avidity of naturally occurring substances for trace metals. III. Pteridines, riboflavin and purine. Biochem. J. $54: 646-654$.

Alexander, M. 1964. Biochemical ecology of soil microorganisms. Ann. Rev. Microbiol. 18:217-252.

Alegeus, S. 1948. The utilization of glycocoll by Chlorella vulgaris. Physiol. Plantarum 1:236-244.

- 1950a. The utilization of aspartic acid succinamide and asparagine by scenedesmus obliquus. Physiol. Plantarum 3:225-235.

- 1950b. Further studies on the utilization of aspartic acid, succinamide, and asparagine by green algae. Physiol. Plantarum 3:370-375.

Allen, H. L. 1969. Primary productivity, chemo-organotrophy, and nutritional interactions of epiphytic algae and bacteria on macrophytes in the littoral of a lake. Ph.D. Thesis, Michigan State University, $186 \mathrm{p}$. 
Allen, H. L. 1971. Chemo-organotrophy in epiphytic bacteria with reference to macrophytic release of dissolved organic matter. Trans. Amer. Microsc. Soc. (In press.)

Allen, M. B. 1955. General features of algae growth in sewage oxidation ponds. State Wat. Poll. Contr. Bd. Publ. 13, Sacramento, Calif.

American Public Health Assoc. et al. 1960. Standard methods for the examination of water and wastewater. Ilth ed. New York, $626 \mathrm{p}$.

Anonymous. 1953. Reference substances for use in organic micro-analysis. Analyst 78:258-259.

Armstrong, F. A. J., P. M. Williams, and J. D. H. Strickland. 1966. Photo-oxidation of organic matter in seawater by ultraviolet radiation, analytical and other applications. Nature 211:481-483.

, and S. Tibbitts. 1968. Photochemical combustion of organic matter in seawater, for nitrogen, phosphorus and carbon determination. J. mar. biol. Assoc. U. K. 48:143-152.

Arnold, D. E. 1969. Feeding studies on Daphnia pulex using seven blue-green algae. Ph.D. Thesis, Cornell Univ.

Banse, K. 1961. Net zooplankton and total zooplankton. Cons. Perm. Int. Exp. Mer. Rapp. Proc. Verb. Reun. $153: 211-215$.

Barber, R. T. 1966. Interaction of bubbles and bacteria in the formation of organic aggregates in seawater. Nature (London) 211:257-258.

Barica, J. 1970. Untersuchen über den StickstoffKreislauf des Titisees and seiner Quellen. Arch. Hydrobiol./Suppl. 38:212-235.

Baylor, E. R., and W. H. Sutcliffe. 1963. Dissolved organic matter in seawater as a source of particulate food. Limnol. Oceanogr. 8:369-371.

Bella, D. A. 1970. Simulating the effect of sinking and vertical mixing on algal population dynamics. J. Wat. Poll. Cont. Fed. 42:R140-R152. 
Billaud, V. A. 1967. Aspects of the nitrogen nutrition of some naturally occurring populations of bluegreen algae. In: Environmental Requirements of Blue-green Algae, U. S. Dept. of Interior, 23-24 Sept., 1966 in Corvallis, Oregon, pp. 35-53.

- 1968. Nitrogen fixation and the utilization of other inorganic nitrogen sources in a subarctic lake. J. Fish. Res. Bd. Can. 25:2101-2110.

Birge, E. A., and C. Juday. 1922. Inland lakes of Wisconsin. The plankton Bull. Wis. Geol. Nat. Hist. Surv. $64: 70-80$. and 1934. Particulate and dissolved organic matter in inland lakes. Ecol. Mono. $4: 440-474$.

Bishop, C. T., E. F. L. J. Anet, and P. R. Gorham. 1959. Isolation and identification of the fast-death factor in Microcystis aeruginosa NRC-1. Can. J. Biochem. Physiol. $37: \overline{453}$.

Botan, E. A., J. J. Miller, and H. Kleerekoper. 1960. A study of the microbiological decomposition of nitrogenous matter in freshwater. Arch. f. Hydrobiol. 56:334-354.

Bozniak, E. G., and L. L. Kennedy, 1968. Periodicity and ecology of the phytoplankton in an oligotrophic and eutrophic lake. Can. J. Bot. 46:1259-1271.

Bradstreet, R. B. 1965. The Kjeldahl Method for Organic Nitrogen. Academic Press, N. Y., 239 p.

Breger, I. A. 1963. Organic Geochemistry. Macmillan, N. Y., $658 \mathrm{p}$.

Brehm, J. 1967. Untersuchungen über den AminosaureHanshalt holsteinischer Gewässer, insbesondere des Pluss-Sees. Arch. f. Hydrobiol./Suppl. 32:313-425.

Brock, T. D. 1966. Principles of Microbial Ecology. Prentice-Hall, Englewood Cliffs, N. J. 306 p.

- 1970. Biology of Microorganisms. PrenticeHall, Englewood Cliffs, N. J. 737 p.

Butler, E. I., E. D. S. Corner, and S. M. Marshall. 1970. On the nutrition and metabolism of zooplankton. VII. Seasonal survey of nitrogen and phosphorus excretion by Calanus in the Clyde sea area. J. mar. biol. Assoc. U. K. 50:525-560. 
Caldwell, D., and P. Hirsch. 1971. The use of a twodimensional steady state diffusion system in the growth of microorganisms. J. Gen. Microbiol. 63: (In press.).

Chandler, D. C., and O. B. Weeks. 1945. Limnological studies of western Lake Erie. Ecol. Mono. 15: 437-457.

Chave, K. E. 1970. Carbonate-organic interactions in sea water. In: Organic Matter in Natural Waters, D. J. Hood (ed), Occas. Publ. No. 1, Univ. Alaska Inst. Mar. Sci., pp. 373-385.

, and E. Suess. 1967. Suspended minerals in seawater. Trans. N. Y. Acad. Sci., Series II, 29: $991-1000$.

- and 1970. Calcium carbonate saturation in seawater: Effects of dissolved organic matter. Limnol. Oceanogr. 15:633-637.

Corner, E. D. S., and B. S. Newell. 1967. On the excretion and metabolism of zooplankton. IV. Forms of nitrogen excreted by Calanus. J. mar. biol. Assoc. U. K. 47:113-120.

Dahr, N. R., and A. Ram. 1933. Variation in the amounts of ammoniacal and nitric nitrogen in rain water of different countries and the origin of nitric nitrogen in the atmosphere. J. Indian Chem. Soc. (Calcutta) 10:125-133.

Danforth, W. F. 1962. Substrate assimilation and heterotrophy. In: Physiology and Biochemistry of Algae. R. A. Lewin (ed), Academic, N. Y. 929 p., pp. 99-124.

Davies, G. S. 1970. Productivity of macrophytes in Marion Lake, British Columbia, J. Fish. Res. Bd. Can. 27:71-81.

Davies, M. B. 1971. Land use and erosion rates in southern Michigan. Abst., Bull. Ecol. Soc. Amer. $52(2): 43$.

Deeter, E. B., and F. W. Trull. 1928. Soil Survey of Barry County, Michigan. U. S. Dept. Agr. Bur. Chem. Soils Ser. No. $14,22 \mathrm{p}$. 
Deevey, E. S., Jr. 1940. Limnological studies in Connecticut. V. A contribution to regional limnology. Amer. J. Sci. 238: 717-741. - 1955. The obliteration of the hypolimnion. Mem. Ist. Ital. Idrobiol., suppl. 8:9-38. 1970. Mineral cycles. Sci. Amer. 223:148158 .

- 1971. Nutrient cycles--major nutrients. In: Nutrients and Eutrophication, G. E. Likens (ed), Amer. Soc. Limnol. Oceanogr., Allen Press, Lawrence, Kan. (In press.)

Doelle, H. W. 1969. Bacterial Metabolism. Academic, N. Y., $486 \mathrm{p}$.

Domogalla, B. P., and Fred., E. B. 1926. Ammonia and nitrate studies of lakes near Madison, Wisconsin. J. Amer. Soc. Agron. 18:897-911.

, C. Juday, and W. H. Peterson. 1925. The forms of nitrogen found in certain lake waters. $J$. Biol. Chem. 63:269-285.

Dooren de Jong, L. E. 1967. Dark and light metabolism of amino acids in Chlorella vulgaris. Antonie van Leeuwenhoek 33:166-170.

Droop, M. R. 1957. Auxotrophy and organic compounds in the nutrition of marine phytoplankton. J. Gen. Microbiol. 16:286-293.

Dugdale, R. C., and J. J. Hoering. 1967. Uptake of new and regenerated nitrogen in primary productivity. Limnol. Oceanogr. 12:196-206.

Duursma, E. K. 1968. Organic chelation of ${ }^{60} \mathrm{Co}$ and ${ }^{65} \mathrm{Zn}$ by leucine in relation to sorption by sediments. in: Organic Matter in Natural Waters. D. J. Hood (ed), Occas. Publ. No. 1, Univ. Alaska Inst. Mar. Sci., pp. 387-397.

Edmondson, W. T. (ed). 1959. Freshwater Biology. By H. B. Ward and G. C. Whipple. J. Wiley and Sons, N. Y.

Ehrlich, G. G., and K. V. Slack. 1969. Uptake and assimilation of nitrogen in microecological systems. Microorganic Matter in Water, ASTM STP 448, Amer. Soc. Test. and Materials, pp. 11-23. 
Eppley, R. W., and F. M. MaciasR. 1963. Role of the alga Chlamydomonas mundana in anaerobic waste stabilization lagoons. Limnol. Oceanogr. 8:411-416.

, and J. N. Rogers. 1970. Inorganic nitrogen assimilation of Ditylum Brightwellii, a marine plankton diatom. J. Phycol. 6:344-351.

Esumi, H., and Y. Saijo. 1969. Determination of dissolved organic matter in natural waters by ultraviolet oxidation. In Japanese, Engl. Summary. Geochemistry 3:1-8.

Fetterolf, C. 1952. A population study of the fishes of Wintergreen Lake, Kalamazoo County, Michigan: With notes on movement and effect of netting on condition. M. S. Thesis, Michigan State Univ.

Filner, P. 1966. Regulation of nitrate reductase in cultured tobacco cells. Biochim. Biophys. Acta $118: 299-310$.

Fisher, D. W., A. W. Gambell, G. E. Likens, and F. H. Bormann. 1968. Atmospheric contributions to water quality of streams in the Hubbard Brook Experimental Forest, New Hampshire. Wat. Res. Res. 4:1115-1126.

Fitzgerald, G. P. 1968. Dectection of limiting or surplus nitrogen in algae and aquatic weeks. J. Phycol. 4:121-126.

- 1969a. Evaluations of the availability of sources of nitrogen and phosphorus for algae. J. Phycol. 6:239-247.

- 1969b. Discussion. In: Environmental Requirements of Blue-green Algae, U. S. Dept. Interior, 23-24 Sept. 1966, Corvallis, Oregon, pp. 97-102.

Fogg, G. E. 1952. The production of extracellular nitrogenous substances by a blue-green alga. Proc. Roy. Soc. B. $139: 372-397$.

- 1953. The metabolism of algae. Methuen, N. Y. 149 P.

- 1959. Nitrogen nutrition and metabolic patterns in algae. Symp. Soc. exp. Biol. 13: 106-125. 
Fogg, G. E. 1966. Algal cultures and phytoplankton ecology, Univ. Wisconsin Press, Madison, 126 p.

- C. Nalewajko, and W. D. Watt. 1965. Extracellular products of phytoplankton photosynthesis. Proc. Roy. Soc. B. 162:517-534.

, and Westlake. 1955. The importance of extracellular products of algae in freshwater. Verh. Int. Verein. Limnol. 12:219-232.

Fonden, R. 1969. Nutritional classification of some limnic bacterial populations. Oikos 20:373-383.

Gerloff, G. C., and F. Skoog. 1957. Nitrogen as a limiting factor for the growth of Microcystis aeruginosa in southern Wisconsin lakes. Ecology 38:556-561.

Gessner, F. 1939. Die Phosphorarmut der Gewässer und ihre Beziehung zum Kalkgehalt. Int. Rev. ges. Hydrobiol. u. Hydrogr. 35:202-21l.

Glimcher, M. J. 1960. Specificity of the molecular structure of organic matrices in mineralization. pp. 421-487, In: Calcification in Biological Systems, R. F. Sognnaes (ed), Amer. Assn. Advan. Sci. Publ. 64, Washington, D. C. 511 p.

Gliwicz, Z. M. 1967. The contribution of nannoplankton in pelagial primary production in some lakes with varying trophy. Bull. de 1 'Academie Polonaise des Sciences $15(6): 343-347$.

Gocke, K. 1970. Untersuchungen über Abgate und Aufnahme von Aminosäuren und Polypeptiden durch Planktonorganismen. Arch. Hydrol. 67:285-367.

Goering, J. J., R. C. Dugdale, and D. W. Menzel. 1964 . Cyclic diurnal variations in the uptake of ammonia and nitrate by photosynthetic organisms in the Sargasso Sea. Limnol. Oceanogr. 9:448-45l.

Goldman, C. R., and R. G. Wetzel. 1963. A study of the primary productivity of Clear Lake, Lake County, California. Ecology 44:283-294.

Golterman, H. L. 1969. Methods for chemical analysis of fresh waters. IBP Handbook No. 8, Blackwell Publ., Oxford, England, $172 \mathrm{p}$. 
Gorham, E. 1958. Observations on the formation and breakdown of the oxidized microzone at the mud surface of lakes. Limnol. Oceanogr. 3:291-298.

Gorham, P. R. 1964. Toxic Algae. In: Algae and Man, D. F. Jackson (ed), Plenum Press, N. Y., pp. 307336 .

Graffius, J.H. 1963. A comparison of algal floras in two lake types, Barry County, Michigan. Ph.D. Thesis, Michigan State University, $479 \mathrm{p}$.

Guillard, R. R. L. 1963. Organic sources of nitrogen for marine centric diatoms. In.: Symp. Marine Microbiol., C. H. Oppenheimer (ed), C. C. Thomas Publ., Ill. pp. 93-104.

Hall, D. J., W. E. Cooper, and E. E. Werner. 1970. An experimental approach to the production dynamics and structure of freshwater animal communities. Limnol. Oceanogr. 15:839-928.

Haney, J. F. 1970. Seasonal and spatial changes in the grazing rate of limnetic zooplankton. Ph.D. Thesis, Univ. of Toronto, Toronto, Canada, $177 \mathrm{p}$.

Harper, J. E., and B. M. Paulsen. 1969a. Nitrogen assimilation and protein synthesis in wheat seedlings as affected by mineral nutrition. I. Macronutrients. Plant Physiol. 44:69-74. , and 1969b. Nitrogen assimilation and protein synthesis in wheat seedlings as affected by mineral nutrition. II. Micronutrients. plant Physiol. 44:636-640.

Harwood, J. E., and D. J. Huyer. 1970a. Some aspects of the phenylhypochlorite reaction as applied to ammonia analysis. Wat. Res. 4:501-515.

, and - 1970b. Automated analysis of ammonia in water. Wat. Res. 4:695-704.

Hayes, F. R., B. L. Reid, and M. L. Cameron. 1958. Lake water and sediment. II. Oxidation-reduction relations at the mud-water interface. Limnol. oceanogr. $3: 308-317$.

Hellebust, J. A. 1965. Excretion of some organic compounds by marine phytoplankton. Limnol. Oceanogr. $10: 192-206$. 
Hellebust, J. A., and R. R. L. Guillard. 1967. Uptake specificity for organic substrates by the marine diatom Melosira nummuloides. J. Phycol. 3:132-136.

Hem, J. D. 1959. Study and interpretation of the chemical characteristics of natural waters. Geol. Surv. Wat. Supply Pap. 1473, U. S. Dept. Interior, U. S. Govern. Print. Off. 269 p.

Hobbie, J. E., and C. C. Crawford. 1969. Bacterial uptake of organic substrate: New methods of study and application to eutrophication. Verh. Int. Verein. Limnol. 17:725-730.

in an estuary. Science 159:1463-1464.

, and R. T. Wright. 1965. Bioassay with bacterial uptake kinetics: Glucose in freshwater. Limnol. Oceanogr. 10:471-474.

Hodson, R. C., and J. F. Thompson. 1969. Metabolism of urea by Chlorella vulgaris. Plant Physiol. $44: 691-6 \overline{96}$.

Holmes, R. W., and G. C. Anderson. 1963. Size fraction-

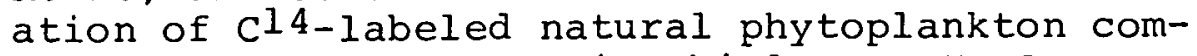
munities. Symp. Mar. Microbiol., C. H. Oppenheimer (ed), C. C. Thomas, Publ. Springfield, Ill. pp. $241-250$.

Hood, D. W. (ed). 1970. Organic Matter in Natural Waters, Occas. Publ. No. 1, Inst. Mar. Sci., Univ. Alaska, $625 \mathrm{p}$.

Hough, J. L. 1958. Geology of the Great Lakes. Univ. Illinois Press, Urbana, Ill.

- 1963. The prehistoric Great Lakes of North America. Amer. Sci. 51:84-109.

Hutchinson, G. E. 1938. On the relation between the oxygen deficit and the productivity and typology of lakes. Int. Rev. d. ges. Hydrobiol. u. Hydrogr. $36: 336-355$.

- 1941. Limnological studies in Connecticut. IV. The mechanisms of intermediary metabolism in stratified lakes. Ecol. Mono. 11:21-60. - 1957. A Treatis on Limnology. Vol. I, Wiley, N. Y., $1015 \mathrm{p}$. 
Hutchinson, G. E. 1967. A Treatis on Limnology. Vol. II. Wiley, N. Y., $1115 \mathrm{p}$.

et al. 1970. Ianula: An account of the history and development of the Lago Di Monterosi, Latium, Italy Trans. Amer. Philos. Soc. $60(4): 1-178$.

Hutner, S. H., and L. Provasoli. 1964. Nutrition of algae. Ann. Rev. Plant Physiol. 15:37-56.

Hynes, H. B. N., and N. K. Kaushik. 1969. The relationship between dissolved nutrient salts and protein production in submerged autumnal leaves. Verh. Internat. Verein. Limnol. 17:95-103.

Jawed, M. 1969. Body nitrogen and nitrogenous excretion in Neomysis rayii Murdoc and Euphausia pacifica Hansen. Limnol. Oceanogr. 1 $\overline{4: 748-754}$.

Johannes, R. E., and K. L. Webb. 1965. Release of dissolved amino acids by marine zooplankton. Science $150: 76-77$.

, S. J. Coward; and K. L. Webb. 1969. Are dissolved amino acids an energy source for marine invertebrates? Comp. Biochem. Physiol. $29: 283-288$.

Jones, K., and W. D. P. Stewart. 1969a. Nitrogen turnover in marine and brackish habitats. III. The production of extracellular nitrogen by Calothrix scopulorum. J. mar. biol. Assoc. U. K. $\frac{49: 475-}{488 .}$ 488 .

, and 1969b. Nitrogen turnover in marine and brackish habitats. IV. Uptake of the extracellular products of the nitrogen-fixing alga Calothrix scopulorum. J. mar. biol. Assoc. U. K. $49: 701-716$.

Kay, W. W., and A. F. Gronlund. 1969. Amino acid transport in Pseudomonas aeruginosa. J. Bact. 97:273281 .

Keen, R. E. 1970. A probabilistic approach to the dynamics of natural populations of the Chydoridae (Cladocera, Crustacea), Ph.D. Thesis, Michigan State Univ., $66 \mathrm{p}$.

Keeney, D. R. 1970. Nitrates in plants and waters. J. Milk and Food Technol. 33:425-432. 
Kent, F., and F. F. Hooper. 1965. Studies on iron-binding organic substances from Michigan waters. Pap. Mich. Acad. Sci. Arts Lett. 50:3-10.

Khailov, K. M., and Z. Z. Finenko. 1968. Organic macromolecular compounds dissolved in sea-water and their inclusion into food chains. I. B. P. Symp. on Mar. Prod., pp. 6-18.

Kirk, P. L. 1950. Kjeldahl method for total nitrogen. Anal. Chem. 22:354-358.

Kitano, Y., N. Kanamori, and A. Tokuyama. 1970. Influence of organic matter on inorganic precipitation. In: Organic Matter in Natural Waters, D. J. Hood (ed), Occas. Publ. No. I, Inst. Mar. Sci., Univ. Alaska, pp. 413-447.

Kjensmo, J. 1968. Iron as the primary factor rendering lakes meromictic, and related problems. Mitt. Internat. Verein. Limnol. 14:83-93.

Kononova, M. M. 1961. Soil organic matter, its nature, its role in soil formation and in soil fertility. English trans. of Russian by T. Z. Nowakowski and G. A. Greenwood, Pergamon, N. Y., 450 p.

, and I. V. Alexandrova. 1958. Biochemical processes of humus formation and certain problems of plant nutrition. Publ. An USSR Seriya Biol. No. $1: 79$.

Kretovich, W. L., Z. G. Evstigneeva, and N. G. Tomova. 1970. Effect of nitrogen source on glutamate dehydrogenase and alanine dehydrogenase of Chlorella. Can. J. Bot. 48:1179-1183.

Kusnetzow, S. I. 1935. Microbiological researches in the study of the oxygenous regimen of lakes. Verh. Internat. Verein. Limnol. 7:563-582.

- 1959. Die Rolle der Mikroorganismen im Stoffkreislauf der Seen. (Transl. from Russian by A. Pochmann), Deutscher Verlag Wissenschaften, Berlin, $301 \mathrm{p}$.

Leverett, F., and B. B. Taylor. 1915. The pleistocene of Indiana and Michigan and the history of the Great Lakes. U. S. Geol. Surv. Monogr. 53. U. S. Gov. Print. Off., 523 p. 
Lewin, J. C. 1963. Heterotrophy in marine diatoms. In: Symp. Mar. Microbiol., D. H. Oppenheimer (ed), C. C. Thomas Publ., IIl., pp. 229-235.

Litchfield, C. O., and J. M. Prescott. 1970. Analysis by dansylation of amino acids dissolved in marine and freshwaters. Limnol. Oceanogr. 15:250-256.

Lohmann, H. 1903. Neue Untersuchungen über den Reichtum des Meeres an Plankton und über die Brauchbarkeit der verschiedenen Fangmethoden. Komm. Wissensch. Untersuch. d. Deutschen Merre im Kiel und $d$. Biologischen Anstalt auf Helgoland, Wiss. Meeresunters., N. F. Abt. Kiel 7:1-86.

Lund, J. W. F., C. Kipling, and E. D. LeCren. 1958. The inverted microscope method for estimating algal numbers and the statistical basis of estimations by counting. Hydrobiologia 11:143-170.

Manny, B. A. 1969. The relationship between organic nitrogen and the carotenoid to chlorophyll a ratio in five freshwater phytoplankton species. Limnol. Oceanogr. 14:69-79.

, M. C. Miller, and R. G. Wetzel. 1971. Ultraviolet combustion of dissolved organic nitrogen compounds in lake waters. Limnol. Oceanogr. $16: 71-85$.

Manskaya, S. M., and T. V. Drozdova. 1968. Geochemistry of organic substances. (Trans. from Russian by L. Shapiro and I. A. Breger), Pergamon Press, N. Y., $345 \mathrm{p}$.

Margalef, R. 1968. Perspectives in ecological theory. Univ. Chicago Press, Chicago, Ill., lll p.

Markham, R. 1942. A steam distillation apparatus suitable for micro-kjeldahl analysis. Biochem. J. 36: $712-715$.

Mathews, C. P., and A. Kowalczewski. 1969. The disappearance of leaf litter and its contribution to production in the River Thames. J. Ecol. 57: 543-552.

Matson, W. R. 1968. Trace metals, equilibrium and kinetics of trace metal complexes in natural media. Ph.D. Thesis, Mass. Inst. Tech., Cambridge, Mass. $257 \mathrm{p}$. 
McCarter, J. A., F. R. Hayes, L. H. Jodrey, and M. L. Cameron. 1952." Movement of materials in the hypolimnion of a lake as studied by the addition of radioactive phosphorus. Can. J. Zool. $30: 128-133$.

McCoy, E., and W. B. Sarles. 1969. Bacteria in lakes: Populations and functional relations. In: Eutrophication: Causes, Consequences, Correctives. Natl. Acad. Sci., Washington, D. C., pp. 331-339.

Mckee, H. S. 1962. Assimilation of organic nitrogenous compounds. In: Nitrogen Metabolism in Plants, Clarendon Press, Oxford, England, 728 p., pp. 126138 .

McLaren, A. D., and D. Shugar. 1964. Photochemistry of proteins and nucleic acids. Macmillan, N. Y., $449 \mathrm{p}$.

Megard, R. O. 1968. Planktonic photosynthesis and the environment of calcium carbonate deposition in lakes. Interim Report 2, Limnological Research Center, Univ. Minnesota, $47 \mathrm{p}$.

Miller, M. C. 1971. Primary and extracellular production by phytoplankton and its role in carbon cycling in lakes. Ph.D. Thesis, Michigan state University.

Minotti, P. L., D. C. Williams, and W. A. Jackson. 1969. Nitrate uptake by wheat as influenced by ammonium and other cations, Crop Sci. 9:9-14.

Morris, I., and P. J. Syrett. 1963. The development of nitrate reductase in Chlorella and its repression by ammonium. Arch. Mikrobiol. 47:32-41.

Mortimer, C. H. 1941-42. The exchange of dissolved substances between mud and water in lakes. J. Ecol. 29:280-329 and 30:147-201.

- 1969. Physical factors with bearing on eutrophication in lakes in general and in large lakes in particular. In: Eutrophication: Causes, Consequences, Correctives, Natl. Acad. Sci., Washington, D. C., pp. 340-368. 
Moss, B. 1969. Algae of two Somersetshire pools: Standing crops of phytoplankton and epipelic algae as measured by cell numbers and chlorophyll a. J. Phycol. 5:158-168.

Mullin, M. M., P. R. Sloan, and R. W. Eppley. 1966. Relationship between carbon content, cell volume and area in phytoplankton. Limnol. Oceanogr. $11: 307-311$.

Neese, J.C., R. C. Dugdale, V. A. Dugdale, and J. Goering. 1962. Nitrogen metabolism in lakes. I. Measurement of nitrogen fixation with $15 \mathrm{~N}$. Limnol. Oceanogr. $7: 163-169$.

Nicol, J. A. C. 1967. Excretion. In: The Biology of Marine Animals, Pitman (ed), 699 p., pp. 276-30l.

North, B. B., and G. C. Stephens. 1967. Uptake and assimilation of amino acids by platymonas.

Biol. Bull. 133:391-400.

, and 1968. Dissolved amino acids and Platymonas nutrition. 6th Internat. Seaweed Symp. 9-13 Sept. 1968. Santiago de Compostela, Spain.

Nursall, J. R. 1969. The general analysis of a eutrophic system. Verh. Internat. Verein. Limnol. 17:109115 .

O'Brien, W. J. 1970. The effects of nutrient enrichment on the plankton community in eight experimental ponds. Ph.D. Thesis, Michigan State University, $180 \mathrm{p}$.

Ohle, w. 1935. Organische Kolloide in ihrer Wirkung auf den Stoffhaushalt der Gewässer. Naturwissenschaften $28: 480-484$.

- 1937. Kolloidgelle als Nährstoffregulatoren der Gewässer. Naturwissenschaften 29:471-474.

Olsen, R. J., O. J. Attoe, and S. A. Witzel. 1968. Progress report on the nitrogen cycle phase of Water Resources Grant \#14-01-0001-858. (Mimeo).

Otsuki, A. 1968. Biogeochemical studies of the production of the dissolved organic matter in relation to food chain of hydrosphere. Ph.D. Thesis, Tokyo Metropol. Univ., $79 \mathrm{p}$. 
Otsuki, A. 1971. Coprecipitation of nitrilotriacetic acid by precipitation of aluminum and ferric hydroxides. (In press.)

, and T. Hanya. 1967. Some precursors of humic acid in recent lake sediment suggested by infrared spectra. Geochim. Cosmochim. Acta 31:15051515 .

, and R. G. Wetzel. 1971. Coprecipitation of phosphate with carbonates in a marl lake. (In press.)

, T. Hanya, and H. Yamagishi. 1969. Residue from bacterial decomposition of green algae cells as food for Daphnia. Nature 222:1182.

Parker, B. C. 1968. Rain as a source of vitamin $B_{12}$. Nature 219:617-618.

Parsons, T. R., and J. D. H. Strickland. 1963. Discussion of spectrophotometric determination of marineplant pigments, with revised equations for ascertaining chlorophylls and carotenoids. J. Mar. Res. 21:155-163.

Patrick, R., and C. W. Reimer. 1966. The diatoms of the United States. Vol. I. Monograph 13, Acad. Nat. Sci. of Philadelphia, $688 \mathrm{p}$.

Pautard, G. E. 1960. Calcification in unicellular organisms. In: Calcification in Biological Systems, R. F. Sognnaes (ed), Amer. Assoc. Advan. Sci. Publ. 64, Washington, D. C., 511 p., pp. 1-14.

Pavoni, M. 1963. Die Bedeutung des Nannoplanktons im Vergleich zum Netzplankton. Qualitative and quantitative Untersuchungen im Zurichsee, Pafäffikersee und anderen Seen. Schweiz. Z . Hydrol. 25:219-342.

Pearsall, W. H. 1932. Phytoplankton of the English lakes. II. The composition of the phytoplankton in relation to dissolved substances. J. Ecol. $20: 241-262$.

Perfil'ev, B. V., and D. R. Gage. 1969. Capillary methods of investigating microorganisms. English transla. by J. M. Shewan., Univ. of Toronto Press, Toronto, Canada, $627 \mathrm{p}$.

Perkins, S. O., and J. Tyson. 1922. Soil survey of Kalamazoo County, Michigan, U. S. Dept. Agr. Survey. 
Peterson, W. H., E. B. Fred, and B. P. Domogalla. 1925. The occurrence of amino acids and other organic nitrogen compounds in lake water. J. Biol. Chem. $63: 287-295$.

Pia, J. 1933. Kohlensäure und Kalk. Die Binnengewässer, Vol. 13, Stuttgart, Schweiz. Verlagsbuchhand, $183 \mathrm{p}$.

Pinter, I. J., and L. Provasoli. 1963. Nutritional characteristics of some Chrysomonads. In: Symp. Mar. Microbiol., C. H. Oppenheimer (ed), C. C. Thomas, Publ., Springfield, Ill., pp. 114-121.

, and 1968. Heterotrophy in subdued light of three Chrysochromulina species. Bull. Misaki Mar. Biol. Inst. Kyoto University 12:25-31.

Powell, H. B. 1956. The original has this signature-W. K. Kellogg. Prentice-Hall, Englewood Cliffs, N. J., $358 \mathrm{p}$.

Prescott, G. W. 1954. How to know the freshwater algae. Brown Co., Dubuque, Iowa, $272 \mathrm{p}$.

Prochazkova, L. P., P. Blazka, and M. Kralova. 1970. Chemical changes involving nitrogen metabolism in water and particulate matter during primary production experiments. Limnol. Oceanogr. 15:789796 .

Provasoli, L. 1960. Micronutrients and heterotrophy as possible factors in bloom production in natural waters. Trans. Seminar on Algae and Metropolitan Wastes. 27-29 April 1960, Cincinnati, Ohio.

, and J. J.A. Mclaughlin. 1963. Limited heterotrophy of some photosynthetic dinoflagellates. In: Symp. Mar. Microbiol., C. H. Oppenheimer (ed), C. C. Thomas Publ., Springfield, Ill., pp. 105113 .

, and I. J. Pinter. 1960. Artificial media for freshwater algae. In: The Ecology of Algae, C. Tyron and R. Hartman (eds), Univ. Pittsburgh Press, 96 p., pp. 84-96.

Rainwater, F. H., and L. L. Thatcher. 1960. Methods for collection and analysis of water samples. U. S. Geol. Surv. Watersupply Paper 1454, 301 p. 
Rawson, D. S. 1939. Some physical and chemical factors in the metabolism of lakes. Prob. in Lake Biol., Amer. Assoc. Advan. Sci., Publ. 10:65-78.

Rich, P. H. 1970a. Utilization of benthic detritus in a marl lake. Ph.D. Thesis, Michigan State University, $78 \mathrm{p}$.

- 1979b. Post-settlement influences upon a southern Michigan marl lake. Mich. Bot. 9:3-9.

- R. G. Wetzel, and N. Van Thuy. 1971. Distribution, production and role of aquatic macrophytes in a southern Michigan marl lake. Freshwater Biol. 1:3-21.

Ricker, W. E. 1937. Physical and chemical characteristics of Cultus Lake, British Columbia. J. Fish. Res. Bd. Can. 3:363-402.

Robertson, A., and C.F. Powers. 1968. The distribution of organic nitrogen in Lake Michigan. Pap. Mich. Acad. Sci., Arts and Lett. 53:137-151.

Rodhe, W., R. A. Vollenweider, and A. Nauwerck. 1958. The primary production and standing crop of phytoplankton. Perspectives in Marine Biology. A. A. Buzzati-Traverso (ed), Univ. Calif. Press, Berkeley, Calif., pp. 299-322.

Round, F. E. 1965. The Biology of the Algae. Edward Arnold, Ltd., London, 269 p.

Sanderson, W. W. 1953. Studies of the character and treatment of wastes from duck farms. Proc. 8 th Ind. Waste Conf., Purdue Univ., Ext. Ser. Vol. $83: 170-176$.

Saunders, G. W. 1957. Interrelations of dissolved organic matter and phytoplankton. Bot. Rev. 23:389-410.

Scheibner, R. A. 1958. A survey of the insect bottom fauna of a limited area of Wintergreen Lake, Kalamazoo County, Michigan. M. S. Thesis, Michigan State University, $51 \mathrm{p}$.

Sculthrope, C. D. 1967. The biology of aquatic vascular plants. Edward Arnold, Ltd., London, England, $610 \mathrm{p}$. 
Shapiro, J. 1957. Chemical and biological studies on the yellow organic acids of lake water. Limnol. Oceanogr. 2:161-179.

- 1966a. Yellow organic acids in lake water: Differences in their composition and behavior. Proc. I. B. P. Symp. Amsterdam, Holland, 10-16 Oct. 1966 , pp. 202-216.

- 1966b. Iron available to algae: Preliminary report on a new approach to its estimation in lake water through use of the "ferrigram." Proc. I. B. P. Symp., Amsterdam, Holland, 10-16 Oct. 1966, pp. 219-228.

Sheldon, R. W. , and W. H. Sutcliffe, Jr. 1969. Retention of marine particles by screens and filters. Limnol. Oceanogr. 14:441-444.

Shurmann, J. 1964. Untersuchungen über organische Stoffe im Wasser des Zürichsees. Vierteljahrsschrift der Natur-Forschenden Gesellschaft in Zürich, Jahrgang $109: 409-460$.

Sieburth, J. MCN., and A. Jensen. 1968. Studies on algal substances in the sea. I. Gelbstoff (humic material) in terrestrial and marine waters. J. Exp. Mar. Biol. Ecol. 2:174-189. , and 1969. Studies on algal substances in the sea. II. The formation of Gelbstoff (humic material) by exudates of Phaeophyta. J. Exp. Mar. Biol. Ecol. 3:275-289.

Skoog, D. A., and D. M. West. 1969. Fundamentals of Analytical Chemistry. Holt, Rinehart and Winston, N. Y., $835 \mathrm{p}$.

Sloey, W. E. 1970. The limnology of hypereutrophic Lake Butte Des Morts, Wisconsin. Proc. 13th Conf. Great Lakes Res. 1970:951-968.

Smith, G. M. 1950. The Freshwater Algae of the United States. McGraw-Hill, N. Y., 719 p.

Solorzano, L. 1969. Determination of ammonia in natural waters by the phenolhypochlorite method. Limnol. Oceanogr. 14:799-801.

Sowden, F. J., and D. I. Parker. 1953. Amino nitrogen of soils and of certain fractions isolated from them. Soil Sci. 76:201. 
Steel, R. G. D., and J. H. Torrie. 1960. Principles and Procedures of Statistics. McGraw-Hill, N. Y., $481 \mathrm{p}$.

Stephenson, M. E., and R. C. Ball. 1969. Phosphorus and nitrogen contributions to eastern Lake Michigan (Abstr.), 12th Conf. on Great Lakes Res. 5-7 May 1969, Ann Arbor, Mich.

Stevenson, F. J. 1954. Ion exchange chromatography of the amino acids in soil hydrolysates. Soil Sci. Soc. Amer. Proc. 18:373-377.

Stewart, W. D. P. 1963. Liberation of extracellular nitrogen by two nitrogen-fixing blue-green algae. Nature 200:1020-1021.

Steyermark, A. 1961. Microdetermination of nitrogen by the Kjeldahl method. In: Quantitative organic Microanalysis, 2nd ed., Academic, N. Y., 665 p., pp. $188-211$.

Strathmann, R. R. 1967. Estimating the organic carbon content of phytoplankton from cell volume or plasma volume. Limnol. Oceanogr. 12:411-418.

Strickland, J. D. H., and T. R. Parsons. 1968. A practical handbook of seawater analysis. Bull. Fish. Res. Bd. Canada, 167, 311 p.

Str $\phi \mathrm{m}$, K. M. 1933. The nutrition of algae. Arch. Hydrobiol. 25:38-47.

Stumm-Zollinger, E. 1968. Substrate utilization in heterogeneous bacterial communities. J. Wat. Poll. Cont. Fed. 40:R213-R229.

Suess, E. 1968. Calcium carbonate interactions with organic compounds. Ph.D. Thesis, Lehigh Univ., Bethlehem, Pa.

Sylvester, R. O., and G. C. Andersoh. 1964. A lake's response to its environment. J. San. Eng. Div. ASCE, Vol. 90:1-22.

Syrett, P. J. 1962. Nitrogen assimilation. In: Physiology and Biochemistry of Algae, R. A. Lewin (ed), Academic, N. Y., pp. 171-188.

Taub, F. B., and A. M. Dollar. 1965. Control of protein level of algae, Chlorella. J. Food Sci. 30: $359-364$. 
Taylor, A. W., W. M. Edwards, and E. C. Simpson. 1971. Nutrients in streams draining woodland and farmland near Coshocton, Ohio. Wat. Resources Res. $7: 81-89$.

Thienemann, A. 1927. Der Bau des Seebeckens in seiner Bedeutung für den Ablauf der Lebens im See.

Verh. Zool. Bot. Ges., $77 \mathrm{p}$.

Thimann, K. V. 1963. The Life of Bacteria. Macmillan Co., N. Y., 909 p.

Toetz, D. W. 1970. Experiments on the adsorption of ammonium ions by clay particles in natural waters. Wat. Resources Res. 6:979-980.

Utermöhl, H. 1958. Zur Vervollkommung der quantitativen Phytoplanktonmethodik. Mitt. Int. Ver. Limnol. $9: 1-38$.

U. S. Dept. of Commerce. 1970. Weather bureau observing handbook No. 2, Substation observations. U. S. Gov. Print. Off., Washington, D. C., $77 \mathrm{p}$.

Vallentyne, J. R. 1955. A laboratory study of the formation of sediment bands. Amer. J. Sci. 253: 540-552.

Vollenweider, R. A. 1960. Beiträge zur kenntnis optischer eigenschaften der Gewässer und Primärproduktion. Mem. Inst. Ital. Idrobiol. 12:201-244.

- 1968. Scientific fundamentals of the eutrophication of lakes and flowing waters with particular reference to nitrogen and phosphorus as factors in eutrophication. Org. for Econ. Coop. and Develop., Directorate for Sci. Affairs, Paris. (Mimeo).

- 1969. Möglichkeiten und Grenzen elementarer Modele der Stoffbilanz von Seen. Arch. f. Hydrobiol. $66: 1-36$.

, and A. Nauwerck. 1961. Some observations on the i4cmethod for measuring primary production. Verh. Int. Verein. Limnol. 14:134-139.

Wagner, F. S., Jr. 1969. Composition of the dissolved organic compounds in seawater: A review. Contr. Mar. Sci. 14:115-153.

Walton, A. G. 1967. The formation and properties of precipitates. Interscience Publ., Wiley, N. Y., $232 \mathrm{p}$. 
Watanabe, A. 1951. Production in cultural solution of amino acids by the atmospheric nitrogen-fixing blue-green algae. Arch. Biochem. Biophys. $34: 50-55$.

Watt, W. D. 1966. Release of dissolved organic matter from the cells of phytoplankton populations. Proc. Roy. Soc. B. 164:521-551.

- 1969. Extracellular release of organic matter from two freshwater diatoms. Annals of Bot. $33: 427-437$.

Webb, K. L., and R. E. Johannes. 1967. Studies on the release of dissolved free amino acids by marine zooplankton. Limnol. Oceanogr. 12:376-382.

, and 1969. Do marine crustaceans release dissolved amino acids? Comp. Biochem.

Physiol. 29:875-878.

Wetzel, R. G. 1960. Marl encrustation on hydrophytes in several Michigan lakes. Oikos 11:223-236.

- 1964a. A comparative study of the primary productivity of higher aquatic plants, periphyton, and phytoplankton in a large, shallow lake. Int. Rev. ges. Hydrobiol. 49:1-61.

- 1964b. Primary productivity of aquatic macrophytes. Verh. Internat. Verein. Limnol. 15:426436 .

- 1965. Nutritional aspects of algal productivity in marl lakes with particular reference to enrichment bioassays and their interpretation. Mem. Ist. Ital. Idrobiol. 18, Suppl.:137-157.

- 1966a. Variations in productivity of Goose and hypereutrophic Sylyan lakes, Indiana. Invest. Indiana Lakes and Streams 7:147-184.

- 1966b. Productivity and nutrient relationships in marl lakes of northern Indiana. Verh. Internal. Verein. Limnol. 16:321-332.

- 1967. Dissolved organic compounds and their utilization in two marl lakes. J. Hungarian Hydrol. Soc., Hidrologiai Közlöny 47:298-303. 
Wetzel, R. G. 1968. Dissolved organic matter and phytoplanktonic productivity in marl lakes. In: Symposium on biogenic metabolism in freshwaters, chemistry and microbiology. Mitt. Int. Verein. Limnol. 14:261-270.

- 1969a. Factors influencing photosynthesis and excretion of dissolved organic matter by aquatic macrophytes in hard-water lakes. Verh. Int. Ver. Limnol. 17:72-85.

- 1969b. Excretion of dissolved organic compounds by aquatic macrophytes. Bioscience 19: 539-540.

- 1970. Recent and post-glacial production rates of a marl lake. Limnol. Oceanogr. 15:491-503.

- 1971. The role of carbon in hard-water marl lakes. In: Nutrients and Eutrophication, Amer. Soc. Limnol. Oceanogr. Allen Press, Lawrence, Kansas. (In press.)

, and H. L. Allen. 1971. Functions and interactions of dissolved organic matter and the littoral zone in lake metabolism and eutrophication. In: Productivity Problems of Freshwaters. $\mathrm{Z}$. Kajak and A. Hillbricht-Ilkowska (eds). (In press.)

, and D. L. McGregor. 1968. Axenic culture and nutritional studies of aquatic macrophytes.

Amer. Midl. Nat. 80:52-64.

, and B. A. Manny. 1971. Secretion of dissolved organic carbon and nitrogen by aquatic macrophytes. Verh. Int. Verein. Limnol. 18:(in press).

, and D. F. Westlake. 1969. Estimating the quantity and quality of biomass in periphyton. In: A Manual on Methods for Measuring Primary Production in Aquatic Environments, R. A. Vollenweider ( $€ d$ ), Blackwell, Oxford, 213 p., pp. 33-40.

P. H. Rich, H. L. Allen, and M. C. Miller. 1971. Dynamics of autrotrophic productivity of a small marl lake. (In prep.) 
Whiteside, E. P., I. F. Schneider, and R. L. Cook. 1968. Soils of Michigan. Coop. Ext. Ser.

Bull. E-630, Michigan State Univ.

Whitton, B. A. 1965. Extracellular products of bluegreen algae. J. Gen. Microbiol. 40:1-1l.

Willen, T. 1959. The phytoplankton of Gorvaln, a bay of Lake Malaren. Oikos 10:241-274.

- 1961. The phytoplankton of Osbysjon, Djursholm. I. Seasonal and vertical distribution of the species. Oikos 12:36-69.

Williams, P. M. 1967. Sea surface chemistry: Organic carbon and organic and inorganic nitrogen and phosphorus in surface films and subsurface waters. Deep-Sea Res. 14:791-800.

Wright, R. T., and J. E. Hobbie. 1965. The uptake of organic solutes in lake water. Limnol. Oceanogr. $10: 22-28$.

, and 1966. Use of glucose and acetate by bacteria and algae in aquatic ecosystems. Ecology $47: 447-464$.

Yentsch, C. S., and J. H. Ryther. 1958. Relative significance of the net phytoplankton and nanoplankton in the waters of Vineyard Sound. Woods Hole Oceanogr. Inst. No. 984, Vol. 5:231-238!

Yoshimura, S. 1935. A subdivision of the stagnation periods of fresh-water lakes. Arch. Hydrobiol. $28: 236-239$.

Zabicky, J. 1968. Detection, determination and characterization of amines. In: The Chemistry of the Amino Group, Saul Patai (ed), Interscience Pub., Wiley, N. Y., 813 p., pp. 79-160. 